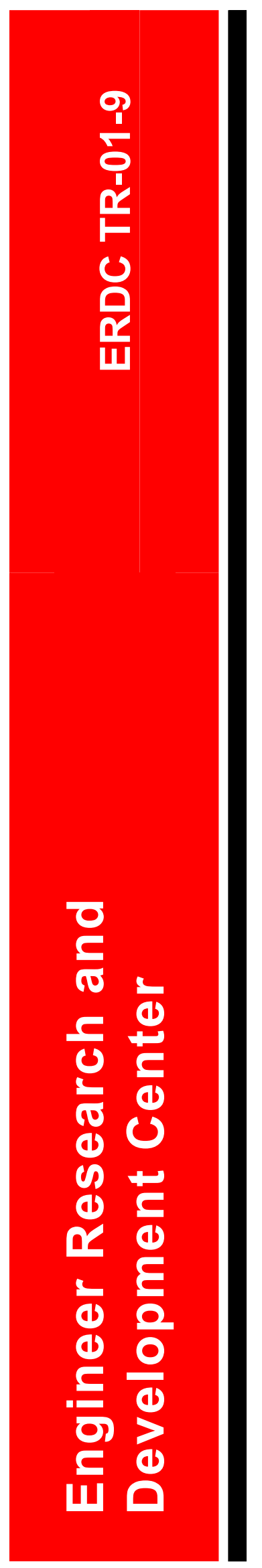

\title{
Instrumentation at the National Center for Asphalt Technology Test Track
}

Reed B. Freeman, H. Tommy Carr, Tom McEwen, and R. Buzz Powell 
The contents of this report are not to be used for advertising, publication, or promotional purposes. Citation of trade names does not constitute an official endorsement or approval of the use of such commercial products.

The findings of this report are not to be construed as an official Department of the Army position, unless so designated by other authorized documents. 
ERDC TR-01-9

August 2001

\title{
Instrumentation at the National Center for Asphalt Technology Test Track
}

\author{
by Reed B. Freeman \\ Geotechnical and Structures Laboratory \\ U.S. Army Engineer Research and Development Center \\ 3909 Halls Ferry Road \\ Vicksburg, MS 39180-6199 \\ H. Tommy Carr \\ Information Technology Laboratory \\ U.S. Army Engineer Research and Development Center \\ 3909 Halls Ferry Road \\ Vicksburg, MS 39180-6199 \\ Tom McEwen \\ 1126 Garner Road \\ Summit, MS 39666-8028 \\ R. Buzz Powell \\ National Center for Asphalt Technology \\ 277 Technology Parkway \\ Auburn, AL 36830-0500
}

Final report

Approved for public release; distribution is unlimited

$\begin{array}{ll}\text { Prepared for } & \text { U.S. Army Corps of Engineers } \\ \text { Washington, DC 20314-1000 }\end{array}$ 



\section{Contents}

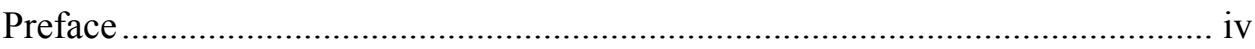

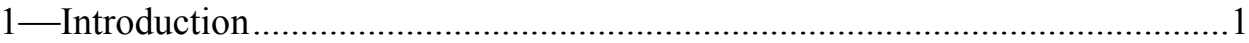

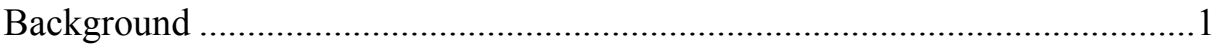

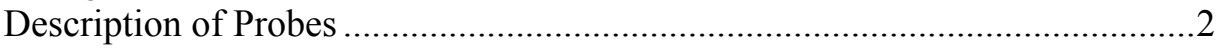

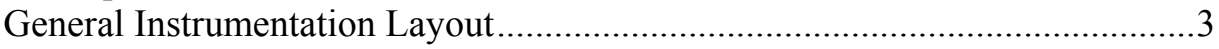

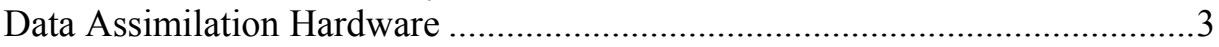

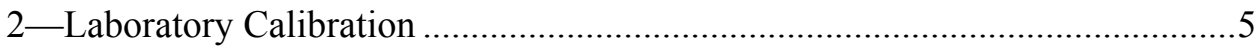

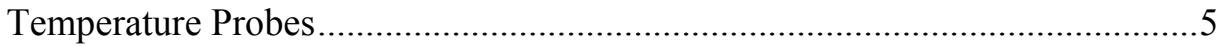

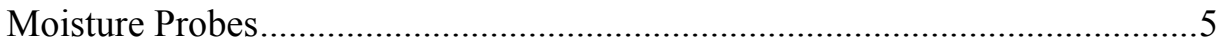

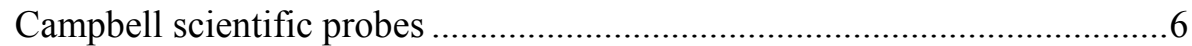

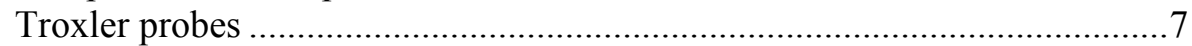

Comments on moisture calibrations ...................................................... 8

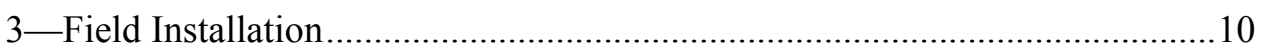

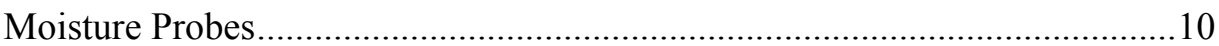

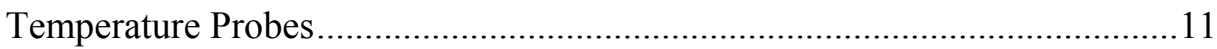

Additional Instrumentation.....................................................................12

4-Probe Measurements at the Test Track........................................................14

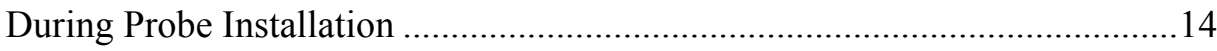

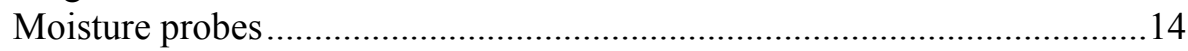

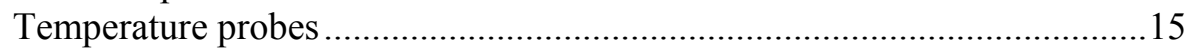

Instantaneous Moisture Measurements .........................................................15

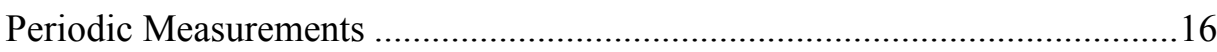

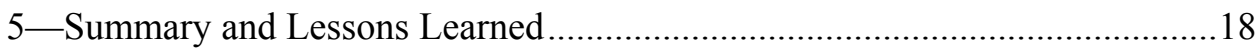

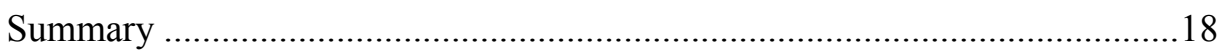

Lessons Learned During Installation.........................................................19

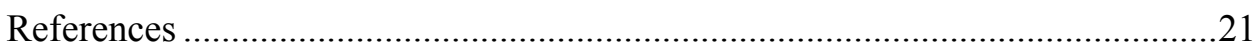

Figures 1-15

Tables 1-16

Photos 1-29

Appendix A: Statistical Analyses

SF 298 


\section{Preface}

The investigation documented in this report was sponsored by the U.S. Army Corps of Engineers through the Research and Development, Testing, and Evaluation (RDT\&E) Program, Work Package 229, Work Unit AT40-AP-005, "Field Validation of Pavement Performance." The Corps of Engineers Technical Monitor was Mr. Ray Navidi, CEMP-ET. This study was conducted by personnel of the Airfields and Pavements Branch (APB), Geotechnical and Structures Laboratory (GSL), U.S. Army Engineer Research and Development Center (ERDC), Vicksburg, MS.

This study was conducted under the general supervision of Dr. Michael J. O’Connor, Director, GSL. Direct supervision was provided by Mr. Don R. Alexander, Chief, APB. The principal investigator for the project was Dr. Reed B. Freeman, APB. The report was authored by Dr. Freeman, Mr. H. Tommy Carr, Operations Branch, Instrumentation Systems Development Division, Information Technology Laboratory, ERDC, Mr. Tom McEwen, private consultant, and Mr. R. Buzz Powell, Test Track Manager, National Center for Asphalt Technology.

At the time of publication of this report, Dr. James R. Houston was Director of ERDC, and COL John W. Morris III, EN, was Commander and Executive Director.

The contents of this report are not to be used for advertising, publication, or promotional purposes. Citation of trade names does not constitute an official endorsement or approval of the use of such commercial products. 


\section{Introduction}

\section{Background}

The National Center for Asphalt Technology (NCAT) completed construction of an oval test track during the year 2000. The Engineer Research and Development Center (ERDC) assisted with the installation of instrumentation between November 1999 and September 2000. Moisture probes were installed in the improved roadbed subgrade and temperature probes were installed in the asphalt concrete. The purpose of this report is to document the installation of the probes and to present initial environmental measurement data.

The test track is oval in shape, with a total centerline length of $2.7 \mathrm{~km}$ (1.7 miles) (Photo 1). The track is located on 309 acres of land in Opelika, Alabama, approximately 20 miles from Auburn University. The purpose of the track is to study asphalt concrete mixtures. Therefore, the track was designed to be extremely stiff (AASHTO structural number $=10.8$ ), so that pavement rutting failures would occur in the top 75 to $100 \mathrm{~mm}$ (3 to 4 in.) of asphalt concrete. Nine different state Departments of Transportation (DOTs) and the Federal Highway Administration (FHWA) all provided funding so that they could each participate in the design of asphalt concrete mixtures for specific pavement test items. Traffic is applied with triple-trailer trucks, traveling in a counterclockwise direction (Photo 2). Within two years, the trucks will have applied 10 million equivalent single-axle loads (ESALs).

The general layout of track test items is shown in Figure 1, along with the locations of the laboratory and the portable asphalt drum-mix plant that was used during paving operations. A schematic drawing of a typical pavement crosssection is shown in Figure 2. The foundation soil consisted of red micaceous clayey silt or bedrock. The select fill consisted of the same silt blended with sedimentary rock with a maximum size of approximately $100 \mathrm{~mm}$ (4 in.). All pavement layers up to the experimental asphalt concrete surface course (i.e., top 75 to $100 \mathrm{~mm}$ ) remained the same all the way around the track. The experimental surface course was different for each pavement test item and was designed with input from the participating state DOTs and the FHWA. 


\section{Description of Probes}

One type of temperature probe was installed: the Model 108 temperature probe, manufactured by Campbell Scientific, Inc. These probes were designed for use in air, soil, and water (Campbell Scientific, Inc. 1996). They cost approximately $\$ 70$ each plus $\$ 1.00$ per meter of cable. The thermistor in each probe is protected within a rigid casing approximately $125 \mathrm{~mm}$ (5 in.) in length and $6 \mathrm{~mm}(1 / 4 \mathrm{in}$.) in diameter (Photo 3). While cable lead lengths of up to

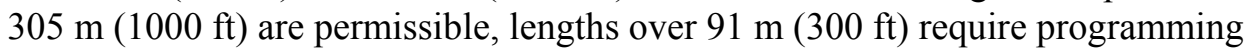
adjustments for increased measurement times. The probes' acceptable temperature measurement range is $-5^{\circ} \mathrm{C}$ to $95^{\circ} \mathrm{C}\left(23^{\circ} \mathrm{F}\right.$ to $\left.203^{\circ} \mathrm{F}\right)$ and their survival temperature range is $-50^{\circ} \mathrm{C}$ to $100^{\circ} \mathrm{C}\left(-58^{\circ} \mathrm{F}\right.$ to $\left.212^{\circ} \mathrm{F}\right)$. The overall probe accuracy is a combination of the thermistors' interchangeability specification, the precision of the probes' bridge resistors, and the error associated with the fifth-degree polynomial used to convert raw voltage measurements to temperatures. All errors considered, accuracy of these probes remains $\pm 0.3^{\circ} \mathrm{C}$ over the range of $-3^{\circ} \mathrm{C}$ to $90^{\circ} \mathrm{C}$ and $\pm 0.7^{\circ} \mathrm{C}$ over the range of $-5^{\circ} \mathrm{C}$ to $95^{\circ} \mathrm{C}$ (Campbell Scientific, Inc. 1996).

Two types of moisture probes were installed: Model CS615 probes purchased from Campbell Scientific, Inc. and Model Sentry 200 probes purchased from Troxler Electronic Laboratories, Inc., Troxler International, Ltd. (Photo 4). The CS615 probes cost approximately $\$ 200$ each, with a cable cost of approximately $\$ 2.00$ per meter. The Sentry 200 probes cost approximately $\$ 900$ each, with a cable cost of approximately $\$ 2.00$ per meter.

Both types of probes detect changes in moisture by detecting changes in the dielectric constant of materials. Most solid materials in soil, such as sand, clay, and organic matter have dielectric constants from 2 to 4 . Water, however, has a much higher dielectric constant of 78 (Campbell Scientific, Inc. 1997). Thus, increases in the moisture content of soil can be identified by measured increases in the soil's dielectric constant.

The Campbell Scientific probes, which are sometimes referred to as water content reflectometers, use time-domain measurement methods. The probes consist of two stainless steel rods connected to a printed circuit board, which is encapsulated in epoxy (Photo 4). The rods are $300 \mathrm{~mm}$ (12 in.) long and $3.2 \mathrm{~mm}$ (1/8 in.) in diameter. They are parallel and are separated by a distance of approximately $50 \mathrm{~mm}(2 \mathrm{in}$.). The epoxy block is $110 \mathrm{~mm}$ (4.3 in.) long, $63 \mathrm{~mm}$ (2.5 in.) wide, and $20 \mathrm{~mm}$ ( 0.8 in) thick. High-speed electronic components on the circuit board are configured as a multivibrator. Output from the multivibrator is transmitted to the rods, which then act as vibration wave guides. The travel time for waves along the rods is dependent on the dielectric constant of the materials surrounding the rods. Readings are affected primarily by material that is between the rods; the effective radius of influential materials can be considered as approximately $50 \mathrm{~mm}(2 \mathrm{in}$.). Typical accuracy for these probes is \pm 2.0 percent moisture by volume if the probes are calibrated for a specific soil (Campbell Scientific, Inc. 1997). 
The Troxler probes estimate moisture by measuring a frequency shift for electromagnetic waves. The electromagnetic waves are generated by two electrical components, which are separated by an insulating spacer. The probes are composed of stainless steel, polypropylene, and fiberglass epoxy. They are cylindrical in shape, with lengths of $260 \mathrm{~mm}$ (10 in.) and maximum diameters of $50 \mathrm{~mm}$ ( 2 in.) (Photo 4). These probes are sleek and they do not have any protruding rods, so they are rugged and they are easily inserted into drilled holes. Readings are influenced by material that is within a radius of approximately $100 \mathrm{~mm}$ (4 in.). Assuming proper calibration and installation, accuracy is expected to be \pm 2.5 percent by volume (Troxler Electronic Laboratories, Inc. 1992).

\section{General Instrumentation Layout}

The moisture probes were installed at one depth: $100 \mathrm{~mm}(4 \mathrm{in}$.$) below the$ top of the select fill. Moisture probes were placed at every second intersection between test items, as shown by the locations of 23 data assimilation stations in Figure 3. A single Campbell Scientific probe was installed at each data assimilation station, positioned in the center of the outside traffic lane. Three Troxler probes were installed at each of two data assimilation stations, as shown in Figure 3. Two of these probes were also positioned in the center of the outside lane and one probe was positioned at the intersection between the outer lane and the shoulder.

Four temperature probes were placed in every test section, within $6 \mathrm{~m}(20 \mathrm{ft})$ of the data assimilation stations. The temperature probes were installed at four different depths within the asphalt concrete, ranging from the bottom of the upper asphalt binder course to the pavement surface. Probes placed at the bottom of the binder course and at the top of the binder course were positioned in the center of the outside traffic lane. Probes placed at the middle of the experimental mix and at the pavement surface were positioned $0.3 \mathrm{~m}(1 \mathrm{ft})$ inside the outer edge of the outside traffic lane.

\section{Data Assimilation Hardware}

Each data assimilation station included a weatherproof enclosure, provided by Campbell Scientific. These enclosures were attached to test section signposts, directly behind the signs, as shown in Photo 5. Two of the 23 stations were also equipped with a Troxler enclosure. These enclosures were also attached to the signposts, as shown in Photo 5.

Each Campbell Scientific enclosure included three components (Photo 6): a power system, a Model CR10X datalogger and an MD9 multidrop interface. The power system included the use of a solar panel, which was mounted to the top of the signpost. The dataloggers served as self-contained, programmable data acquisition systems. They excited gages, collected data, and conditioned signals. 
Each datalogger also included a back-up power supply. The multidrop interfaces were necessary for communicating data back to data acquisitions computers, which were housed in the track laboratory. A desiccant pack was placed in each enclosure; packs are to be replaced every 3 to 6 months. Each data assimilation station was also equipped with a $2.4-\mathrm{m}(8-\mathrm{ft})$ copper-clad grounding rod. The total cost for each station, including enclosure, solar panel, and grounding rod, was approximately $\$ 2000$.

Each Troxler enclosure included a power system and a Troxler ProbeReader Plus data acquisition system (Photo 7). The cost of each Troxler enclosure was approximately $\$ 5000$.

All Campbell Scientific probes (including temperature and moisture) were connected directly to the CR10X dataloggers. The Troxler moisture probes were connected to a Troxler ProbeReader Plus, which was connected in-turn to the CR10X that occupied the same signpost.

Stations were connected to data collection computers in the on-site laboratory via coaxial cables, which were buried and were protected in 32-mm (1.25-in.) O.D. PVC conduit. The conduit actually contained two cables, with one serving as a back-up. The data assimilation stations were linked as two completely separate "daisy chains." Each chain required approximately $1700 \mathrm{~m}$ $(5600 \mathrm{ft})$ of cable and was provided with its own data collection computer. One chain (called the "North leg") included all test sections in the north tangent and most test sections in the west curve (W1 through W9) (Figure 3). The other chain (called the "South leg") included all test sections in the east curve, all test sections in the south tangent, and one test section in the west curve (W10). Two legs were necessary to limit cable lengths and had the advantage of minimizing loss in the case of lightning strike. The contracted price for installing the coaxial cables was approximately $\$ 50,000$.

Each data collection computer is equipped with Campbell Scientific software named PC208, which serves as an interface to each data assimilation station. The software can call each station individually using its unique MD9 multidrop interface address. Using this software, the user can program all CR10X dataloggers from the central computer location. The user can also program a schedule for intermittent data calls. During each data call, the computers retrieve data that is temporarily stored in the dataloggers. 


\section{Laboratory Calibration}

\section{Temperature Probes}

Calibration of these probes was deemed unnecessary. These probes are designed to be interchangeable and they are all sold with a common equation to be used for converting voltage measurements to temperature measurements. Unlike the moisture probes, the temperature probes do not need to be calibrated for the particular environment in which they are to be used.

In order to verify the accuracy of the probes and to demonstrate the consistency between probes, eight probes were placed in three water baths with known temperatures of $0.44^{\circ} \mathrm{C}\left(32.8^{\circ} \mathrm{F}\right), 23.8^{\circ} \mathrm{C}\left(74.9^{\circ} \mathrm{F}\right)$, and $59.3^{\circ} \mathrm{C}\left(138.8^{\circ} \mathrm{F}\right)$. Each probe was equipped with cable lengths of 15.2 to $30.5 \mathrm{~m}(50$ to $100 \mathrm{ft})$. Three replicate temperature measurements were obtained for each probe in each bath. Replicate measurements were obtained during a single immersion. The average temperatures that were measured by probes are shown in Table 1. An analysis of variance was performed for data obtained with each temperature bath. In each analysis, the different probes were the treatment factor, as shown in Tables A1, $\mathrm{A} 2$, and A3. The magnitudes of probe and replicate variability for temperature measurements are shown in Table 2. For data obtained with each temperature bath, the standard deviations of temperature measurements between probes, between replicates, and total were all less than or equal to $0.06^{\circ} \mathrm{C}\left(0.11^{\circ} \mathrm{F}\right)$. Measured temperatures matched the bath temperatures very well (Figure 4). To test the interchangeability of the probes, a linear regression was conducted with both bath temperature and probe number as fixed independent variables. Student's t-tests found probe number to have an insignificant effect on the model (Table 3). In summary, the temperature probes were found to be repeatable, accurate, and interchangeable.

\section{Moisture Probes}

Both types of moisture probes were calibrated within the same material that was to be placed around the probes during their installation at the NCAT test track. This material consisted of the select fill used at the track, with large particles removed. Large particles were removed by passing the soil through a wire mesh with openings approximately the same size as a No. 4 sieve. 


\section{Campbell scientific probes}

The Campbell Scientific probes were calibrated using soil with three target moisture contents: 0,10 , and 20 percent by mass. The soil was mixed at each of the three moisture contents and was compacted in a polyvinyl chloride (PVC) tube, which was approximately $400 \mathrm{~mm}$ (16 in.) tall and had an inside diameter of $150 \mathrm{~mm}$ (6 in.), as shown in Photo 8. The soil was compacted to achieve a density that would be similar to that which would be possible in the vicinity of the probes. The soil was compacted in three layers of equal thickness; each layer received 25 blows from a standard Proctor hammer.

To obtain the data necessary for calibration, each Campbell Scientific probe was used to measure moisture content for the soil in each of the PVC tubes. For each probe, the full length of the parallel, stainless steel rods was pushed into the soil in each PVC tube. Each Campbell Scientific probe was inserted into each tube of soil three times. This provided three replicates of raw data readings. Raw data readings represented the period of electromagnetic wave travel along the rods (ms). Moisture contents for the calibration soils were measured by oven-drying representative samples. The measured moisture contents for the tubes of soil were $0,9.6$, and 20.5 percent by mass.

The average probe measurements obtained during calibrations are shown in Table 4 . The variability between replicate readings was small. The average and maximum coefficients of variation for replicate Campbell Scientific measurements were 1.6 percent and 5.9 percent, respectively.

The calibration equation for the Campbell Scientific probes has the form:

$$
y=a x^{2}+b x+c
$$

where

$$
\begin{aligned}
& \mathrm{y}=\text { gravimetric moisture content (as a decimal) } \\
& \mathrm{x}=\text { measured electromagnetic wave period }(\mathrm{ms})
\end{aligned}
$$

The calibration equation published by Campbell Scientific (Campbell Scientific, Inc. 1996) actually uses volumetric moisture content. Volumetric moisture content is proportional to gravimetric moisture content and can be calculated by multiplying gravimetric moisture content by the specific gravity of soil solids. Due to the common use of gravimetric moisture content in construction, gravimetric moisture content will be used in this report.

Calibration coefficients were obtained for each probe by determining the best-fit curve for a plot of probe measurement versus moisture content. These coefficients are shown in Table 5. Calibration coefficients were also determined for all the probe data when plotted collectively, as shown in Figure 5. These coefficients are included in Table 5 under the name "composite calibration." The first decision to be made is whether to use individual calibrations or the composite calibration. This decision should be based on the relative contri- 
butions of measurement variability provided by both differences between probes and differences between replicates. Therefore, an analysis of variance was conducted for the probe measurement data that was obtained at each moisture content. These analyses are summarized in Tables A4 through A6. These analyses provided information related to two components of variance and their relative magnitudes, as shown in Table 6 . The overall coefficient of variation between probe measurements was less than 3 percent for each moisture content. Also, the total variance was divided approximately equally between probe variance and replicate variance. This information, along with the qualitative judgment of adequate composite curve fitting in Figure 5, resulted in the use of the composite calibration parameters. The Campbell Scientific probes behaved similarly, so they do not require individual calibrations.

\section{Troxler probes}

The Troxler probes were calibrated using soils with four target moisture contents: the as-received moisture content, 0,15 , and 20 percent moisture by mass. The soil was mixed at each of the four moisture contents and was compacted in 18.9-L (5-gal) plastic buckets, which were approximately $350 \mathrm{~mm}$ (14 in.) deep and had an inside diameter of $280 \mathrm{~mm}$ (11 in.), as shown in Photo 9. The soil was compacted in three layers of equal thickness using a 150-mm (6-in.) diameter Marshall hammer. The Marshall hammer was not raised and dropped in a standard manner. The entire device was lifted and dropped from heights of approximately $305 \mathrm{~mm}$ (12 in.). Each lift of material received approximately 25 blows by the hammer. This modified procedure served the primary objective, which was to compact the soil to a density similar to that, which would be obtained in the field.

To obtain the data necessary for calibration, each Troxler probe was used to measure moisture content for the soil in each of the plastic buckets. The full length of each probe was inserted into holes in the soil, which were created using a hand-auger. Soil was compacted around the probes near the soil surface to ensure good contact. While each probe was buried in each bucket, three readings were obtained, providing three replicates of raw data readings. Raw data readings represented a difference between the measured frequency $(1 / \mathrm{s})$ of electromagnetic waves and that of a known standard. Moisture contents for the calibration soils were measured by oven-drying representative samples. The measured moisture contents for the buckets of soil were $0.0,7.7,14.0$, and 19.9 percent by mass.

The average probe measurements that were obtained during calibrations are shown in Table 7. The variability between replicate readings was small. The average and maximum coefficients of variation for replicate Troxler measurements were 0.02 percent and 0.12 percent, respectively. The variability between

replicates was lower for Troxler probes than for Campbell Scientific probes. The most likely cause for this difference was that while the Troxler replicates were obtained during a single probe installation, the Campbell Scientific probes were removed and reinstalled for each replicate. 
The calibration equation for the Troxler probes has the form:

$$
y=\left(\frac{1}{C 1}\right) \ln \left[\frac{(x-C 2)}{C 0}\right]
$$

where

$$
\begin{aligned}
\mathrm{y}= & \text { gravimetric moisture content (as a percent) } \\
\mathrm{x}= & \begin{array}{l}
\text { measured electromagnetic wave frequency difference from a } \\
\text { standard }(1 / \mathrm{s})
\end{array}
\end{aligned}
$$

Similar to the procedure used for the Campbell Scientific probes, calibration coefficients were obtained for each probe by determining the best-fit curve for a plot of probe measurement versus moisture content. These coefficients are shown in Table 8. Calibration coefficients were also determined for all the probe data when plotted collectively, as shown in Figure 6. These coefficients are included in Table 8 under the name, "composite calibration." The analyses of variance for probe measurement data are summarized in Tables A7 through A10. A separate analysis was conducted for data obtained at each calibration moisture content. These analyses provided information related to two components of variance and their relative magnitudes, as shown in Table 9. The overall coefficient of variation between probe measurements was greater than 6 percent at each moisture content. Also, the total variance was almost entirely attributable to variability between probes. This information, along with the qualitative judgment of poor composite curve fitting in Figure 6, resulted in the use of individual probe calibration parameters. In summary, individual Troxler probes behaved sufficiently different from each other to exclude the possibility of using a composite calibration.

\section{Comments on moisture calibrations}

The user's manuals that accompany both Campbell Scientific and Troxler moisture probes urge users to calibrate the probes with the particular soil that is to be instrumented. The data in this study demonstrates the importance of this practice. For the CS615 probes, Figure 7 compares the calibrations produced in this study with the standard calibrations that are offered in the user's manual. The range of standard calibrations shown in the figure reflects the range of electrical conductivities for different soils. Figure 8 compares the factory calibration for Troxler Probe No. 3 with the calibration produced specifically for the soil used at the NCAT Test Track. Probe No. 3 serves as an example in this case; each probe needed its own calibration. The accuracy of moisture measurements were improved for both the Campbell Scientific and Troxler probes by implementing soil-specific calibrations. Improved accuracy was most significant at higher moisture contents.

Although the soil-specific calibrations improved the accuracy of moisture measurements, the calibration coefficients presented in this chapter (Tables 5 and 8 ) are not the final coefficients. A final adjustment was made at the time of 
installing the probes at the test track. This adjustment, which will be described in Chapter 4, will be made possible by comparing initial probe measurements with soil moistures determined by oven drying. 


\section{Field Installation}

\section{Moisture Probes}

At the time of installing the moisture probes, the $0.15-\mathrm{m}$ - (6-in.-) thick crushed granite base course was already in-place. Therefore, at each designated probe location, a hole was dug through the base and $0.125 \mathrm{~m}$ (5 in.) into the select fill. Shallow trenches, reaching a depth of one-half base thickness were also required to run cables to the pavement edge. Placements of Campbell Scientific CS615 probes required only a single, straight trench (Photo 10). The probes were positioned at the center of the outer traffic lane. Placements that involved both a CS615 probe and three Troxler Sentry 200 probes required a "T-shaped" trench (Photo 11). The CS615 probe and two of the Sentry 200 probes were positioned at the center of the outer traffic lane. The CS615 resided in-between the Sentry 200 probes, at the center of the "T-shape." A Sentry 200 probe was then placed on each side of the CS615 probe, separated by a horizontal

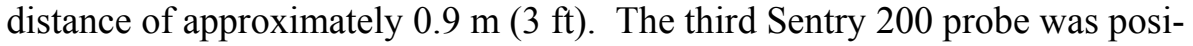
tioned $4.3 \mathrm{~m}(14 \mathrm{ft})$ from the pavement centerline, at the intersection between the outer lane and the shoulder. Installation procedures, which will be described in the following text, were the same for both types of moisture probes.

Two types of aggregate materials were processed in preparation for installing these probes. Select fill was scalped with a No. 4 sieve and the finer fraction was collected. The crushed granite used for base course was scalped with a No. 16 sieve and the finer fraction was collected. The fine fraction of select fill was the same material that was used for probe calibration. This material was placed around probes during installation. Large particles were removing to minimize risk of damaging probes and to improve efficiency of hand-compaction operations. The fine fraction of crushed granite was placed around cables that were buried with the pavement base course. Again, the removal of large particles minimized the risk of damaging cables.

Photo 12 shows a CS615 probe in its final destination. Care was taken to ensure that the cable had some slack. This practice minimizes the risk of cable damage due to tension. Photo 13 shows the same gage location after handcompacting the fine-fraction select fill. After protecting the cable with finefraction crushed granite and after filling the trench with the base course material previously removed, the trench was compacted by both foot and truck tire traffic (Photo 14). 
At the time of installing moisture probes, the pavement contractor was installing edge-drains. The longitudinal shoulder trench can be seen in Photo 14. The moisture probe cables needed protection while the contractors continued pavement construction. For the short-term, the ends of cables were waterproofed and the cables were placed under 19-L (5-gal) buckets. Once the edge-drain construction reached the top of the crushed granite base, the cables were extended through the edge-drains and across the shoulders. They were threaded through 25-mm (1-in.) O.D. PVC pipe (Photo 15). The cables remained in that condition until the pavement and shoulders were completed, at which time the cables were retrieved. To facilitate cable retrieval, a straight PVC pipe connection was positioned near the eventual location of the test section sign and the data assimilation hardware.

\section{Temperature Probes}

Temperature probes were installed during two phases. During the first phase, two thermistors were installed in the asphalt concrete binder course in each test section. These probes were positioned in the center of the outside traffic lane, one at the bottom of the binder course and one at the top of the binder course (Figure 9). During the second phase, two thermistors were installed in the experimental asphalt surface course mixture in each test section. These probes were positioned $0.3 \mathrm{~m}(1 \mathrm{ft})$ inside the shoulder stripe for the outside traffic lane, one placed at the middle of the experimental mix and one placed at the pavement surface.

All temperature probes were installed near the data assimilation stations, as presented in Chapter 1. Because each station was located at a transition between test sections, temperature probes connected to a single station could reach two test sections. Eight temperature probes were connected to each station, four reaching each of two test sections. The probes extended from the stations at approximate 45 -degree angles, forming $\mathrm{V}$-shaped patterns.

The installation process began when the last lift of asphalt binder course was being placed. Ropes were used to form cable trenches in the surface of the binder course. The ropes, which were approximately $25 \mathrm{~mm}$ (1 in.) in diameter, were laid onto the surface of asphalt immediately before rolling compaction. Rollers then pressed the ropes into the asphalt concrete, thus forming the trenches (Photo 16). While one end of the rope remained near the data assimilation station, the other end was positioned at the location where probes were to be installed. A knot was tied in the rope at the probe end in order to widen the trench in that particular area. After the asphalt cooled, the rope was removed from the asphalt concrete, leaving a clean and well-formed cable trench (Photo 17).

To reach the bottom of the binder course, a 13-mm- (0.5-in.-) diam hole was drilled with a hand-drill (Photo 18). A single probe was pushed into the hole and then the cable was strung along the trough. A second probe was placed near the hole, lying horizontally within the trough (Photo 19). A heavily polymer- 
modified asphalt-based binder was used to fill the trough, securing the temperature probes and the cables. To reach flowable condition, the binder was heated to approximately $150^{\circ} \mathrm{C}\left(300^{\circ} \mathrm{F}\right)$. This high heat could damage thermistors, so the surface thermistor was covered with minus No. 16 crushed granite (Photo 20). Photo 21 shows the pouring of binder into a trough. Because the cables tended to float in the binder, they had to be secured within the trench. The best method for securing the cables was found to be U-shaped wire tacks. The pouring sequence for the binder was to first fill the vertical hole as well as possible. There was little space between the probe and the edge of the hole, so this did not require much binder. Then the pouring proceeded toward the data assimilation station. The trench was filled to level and then it was covered with the minus No. 16 crushed granite (Photo 22). After the binder cooled, excess aggregate was swept away and any substantial binder drip spots were removed with a hot flat plate (Photo 23). Note in Photo 23 that the temperature probe cables were threaded through a PVC pipe. Similar to the situation for the moisture probe cables, the temperature probe cables had to be protected during continued paving operations and shoulder construction. The PVC pipe was extended across the shoulder and then when the data assimilation station was set up, the temperature probe cables were retrieved from the pipe.

Probe installation in the experimental surface course mixtures was similar. One probe was installed in each test section during the placement of each of the two asphalt concrete lifts. No drilling was required. However, the color of the material used at the pavement surface became a concern for both aesthetic and measurement accuracy reasons. For each test section, a sample of the appropriate hot-mix was compacted over the temperature probe at the pavement surface (Photo 24). This practice ensured appropriate color and thermal conductivity. As an aesthetic improvement, the color of aggregate used at the pavement surface to protect trench-filling binder was darkened (Photo 25).

\section{Additional Instrumentation}

Two additional environment-related pieces of instrumentation were installed at the test track: a weather station and volume measurement devices for pavement drainage. These instruments were not part of this project, but will be mentioned for completeness. The weather station was positioned near the on-site laboratory at the NCAT test track (Photo 26). It measures air temperature, relative humidity, solar radiation, rainfall, wind speed, and wind direction. All components were purchased as a set from Campbell Scientific, Inc., at a cost of approximately $\$ 5,000$. The contracted cost for assembling and installing the weather station was approximately $\$ 13,000$.

The volume measurement devices, or tipping buckets, were necessary to obtain samples of the effectiveness of the test track subsurface drainage system. The subsurface drainage system included a permeable asphalt-treated base and standard edge-drains. The edge drains used both permeable aggregate and a 0.1-m- (4-in.-) diam perforated pipe. On the straight portions of the track, edgedrains were installed in both pavement shoulders. On the curved portions of the 
track, edge-drains were installed only in the inside shoulder. Edge-drain pipe outlets were installed at intervals of approximately $76 \mathrm{~m}(250 \mathrm{ft})$, as shown in Figure 10. The outlets consisted of rigid PVC pipes that extended laterally from the edge-drain pipes, to the ground surface above a drainage ditch. One outlet in the North tangent was equipped with a tipping bucket and two outlets in the South tangent were equipped with tipping buckets (Figure 10).

The tipping buckets were donated by the Mississippi Department of Transportation. Their design has origins in Wisconsin, so they are often referred to as "Wisconsin tipping buckets." The drainage outlet pipe connects to the top of the tipping bucket (Photo 27). As water enters the tipping bucket, it fills a bowl. Once the bowl fills with approximately $0.5 \mathrm{~L}$ of water, it tips over and empties. For flowing water conditions, the bowl repeatedly fills, tips, and empties. Calibration involves supplying a known flow and counting tips. Calibration provides the user with a precise volume of water per tip. In the field, tips are counted during pre-defined periods of time, thus providing the flow of water.

The tipping buckets at the NCAT test track are protected within prefabricated dog houses (Photo 28). A single wire connects each tipping bucket to a data logger at one of the data assimilation stations that is also used for temperature and moisture probes. The importance of the tipping bucket measurements can be seen in Photo 29, which shows water flow from a drainage outlet after a brief afternoon shower. 


\section{Probe Measurements at the Test Track}

\section{During Probe Installation}

\section{Moisture probes}

Immediately after installing each moisture probe, probe output data were obtained using hand-held keyboard/display units provide by Campbell Scientific (Model CR10-KD). These data were obtained to ensure that the probes were functioning properly and also to permit final adjustments to calibrations. These adjustments were necessary to account for any slight differences between field and laboratory conditions, such as the level of compaction achieved in a shallow trench versus that achieved in a laboratory bucket. Samples of soil were also obtained during probe installation. Soil samples were obtained from the in-situ select fill that was exposed in the vicinity of the probe installation locations. Soil samples were also obtained from the scalped select fill that was placed around the probes during installation. The soil samples were later used to measure oven-dry moisture contents.

Data obtained during the installation of Campbell Scientific probes are shown in Table 10. These data include the probe measurements (with units of $\mathrm{ms}$ ), the estimated moisture contents (using the composite calibration coefficients presented in Chapter 2), and the moisture contents measured by drying soil in an oven. Table 10 also shows the calculated differences between the moisture contents estimated by probes and the oven-dry moisture contents of scalped fill. On the average, probes estimated moisture contents to be 2.9 percent lower than that measured by oven drying. This average difference was expected to be a more accurate correction than individual measured differences. Errors contributed by soil sampling would tend to be minimized with the overall average difference. Also, the correction was intended to reflect primarily differences between field and laboratory conditions. These differences were expected to be similar for all probe installations.

Data obtained during the installation of Troxler probes are shown in Table 11. These data include the probe measurements (with units of $1 / \mathrm{s}$ ), the estimated moisture contents (estimated using the calibration coefficients developed for individual probes), and the moisture contents measured by drying soil in an oven. Similar to Table 10, Table 11 also shows the calculated differences 
between the moisture contents estimated by probes and the oven-dry moisture contents of scalped fill. On the average, probes estimated moisture contents to be 2.5 percent higher than that measured by oven drying. The moisture contents of in-situ select fill were not used for any calibration adjustments. They were obtained as a matter of interest.

The composite calibration for the Campbell Scientific probes was corrected by increasing parameter $\mathrm{c}$ by +0.029 ( 2.9 percent moisture). Neither parameter a nor parameter $\mathrm{b}$ was affected. The final adjusted moisture prediction equation is shown in Table 12, along with all final adjusted moisture content estimates.

The individual calibrations for the Troxler probes were corrected by multiplying parameter $\mathrm{C} 0$ by $+\exp \left(2.5^{*} \mathrm{C} 1\right)$. Neither parameter $\mathrm{C} 1$ nor parameter $\mathrm{C} 2$ was affected. The final adjusted calibration coefficients for each probe are shown in Table 13. The final adjusted moisture content estimates are shown in Table 14.

\section{Temperature probes}

Temperature probe measurements were not recorded during installation because they were not needed for the purpose of adjusting calibration. However, temperatures were monitored during installation for the purpose of ensuring survivability. A probe could become ruined if its temperature exceeded approximately $120^{\circ} \mathrm{C}\left(250^{\circ} \mathrm{F}\right)$. After completing installation, each probed was checked to ensure that it was functioning properly.

\section{Instantaneous Moisture Measurements}

During pavement construction and prior to completing the entire network of instrumentation hardware, several instantaneous moisture measurements were obtained using the hand-held keyboard/display units. Measurements obtained from the CS615 probes are shown in Table 15, while those obtained from the Sentry 200 probes are shown in Table 16. It is apparent from both tables that moisture contents at the top of the select fill increased substantially from November 1999 to February and March 2000. After reaching levels between 20 and 25 percent, moisture contents stabilized. For a portion of the time between November 1999 and February 2000, the base was exposed. Also, the next constructed layer was permeable asphalt-stabilized base, which would still allow quick intrusion by rainfall.

It is apparent from Table 15 that moisture contents were relatively uniform around the track. It is apparent from Table 16 that moisture contents near the pavement shoulder were similar to those at the middle of the outside traffic lane.

Moisture contents in the range of 20 to 25 percent are near 100 percent saturation. This statement is based on the finding that laboratory soil samples could not be produced at moisture contents of 25 percent. At that degree of wetness, 
the samples could not retain all their moisture. When compacting in containers, excess water would collect at the top of the sample. Also, records show the typical dry density for select fill to be about $1840 \mathrm{~kg} / \mathrm{m}^{3}$ (115 pcf). Assuming a specific gravity of solids of $2.9,100$ percent saturation should occur at moisture contents of approximately 20 percent.

\section{Periodic Measurements}

Once all the data acquisition software and hardware was installed, data acquisition became automatic. Dataloggers collect data once each minute, including:

a. Temperature $\left({ }^{\circ} \mathrm{F}\right)$ for each temperature probe.

b. Raw data for each moisture probe (ms for CS615 and $\mathrm{s}^{-1}$ for Sentry 200).

c. Number of tips for the tipping bucket.

d. Enclosure temperature $\left({ }^{\circ} \mathrm{F}\right)$.

e. Battery voltage (V).

All the dataloggers collect temperature measurements from each of eight probes. Twenty-one of the 23 dataloggers collect moisture measurements from only one CS615 probe. The remaining two dataloggers collect moisture measurements from four probes (one CS615 and three Sentry 200). Only three of the 23 dataloggers collect tipping bucket measurements.

At the end of each hour, the dataloggers summarize the one-minute-interval measurements for temperature and moisture with minimum, maximum, and average. For the tipping buckets, however, the one-minute-interval measurements are summed and the dataloggers convert total number of tips to hourly volume in liters. The dataloggers are programmed with the appropriate tipping bucket calibrations. For the moisture probes, the dataloggers convert raw data to moisture content using the appropriate calibrations. Moisture content is reported as a decimal for CS615 probes and as a percent for Sentry 200 probes.

The data acquisition computers retrieve data from the dataloggers once each hour and save the data to designated ASCII files. However, the computers can remain offline for up to approximately three months without causing the loss of any data. The dataloggers have sufficient memory to store summarized data for that period of time. The order of temperature probes in the data files, presented from left to right, is shown in Figure 11. The order of moisture probes in the data files, presented from left to right, is: the CS615 probe and then the three Sentry 200 probes. The Sentry 200 probes are presented in the following order: first, the probe at the shoulder/traffic lane interface and then two probes at the center of the outside traffic lane (in the same order that they are met by traffic). 
Data from three dataloggers will be used in this report as the sources of example measurements. These dataloggers were selected because they are spread out around the track and each includes a tipping bucket. One datalogger is positioned between test sections $\mathrm{N} 3$ and $\mathrm{N} 4$, the second datalogger is positioned between test sections $\mathrm{W} 10$ and $\mathrm{S} 1$, and the third datalogger is positioned between test sections S8 and S9.

An example of temperature fluctuations at the pavement surface is shown in Figure 12. This particular probe is positioned at the surface of test section S1. Both seasonal and daily trends are apparent. During the month of December 2000 , the temperature reached a minimum of approximately $-6^{\circ} \mathrm{C}\left(21^{\circ} \mathrm{F}\right)$. During the month of June 2001 , the temperature reached a maximum of $60^{\circ} \mathrm{C}\left(140^{\circ} \mathrm{F}\right)$.

Temperature fluctuations occurring over a single day in September 2000, and at four depths in the pavement, are shown in Figure 13. Temperatures at the pavement surface experienced the largest and quickest fluctuations. While temperatures at the pavement surface fluctuated from $20^{\circ} \mathrm{C}\left(68^{\circ} \mathrm{F}\right)$ to $50^{\circ} \mathrm{C}\left(122^{\circ} \mathrm{F}\right)$, temperatures at the bottom of the upper binder course fluctuated over a smaller range: $29^{\circ} \mathrm{C}\left(84^{\circ} \mathrm{F}\right)$ to $35^{\circ} \mathrm{C}\left(95^{\circ} \mathrm{F}\right)$. While temperatures at the pavement surface peaked at $1500 \mathrm{hr}$, temperatures at the bottom of the upper binder course didn't peak until $2000 \mathrm{hr}$.

Moisture trends from September 2000 to February 2001 are shown in Figure 14. Over the nine-month period, moisture contents in the select fill remained relatively constant. Moisture contents were also relatively uniform around the test track. Drainage outflow measurements from October 2000 to February 2001 are shown in Figure 15. Many rainfall events are evident for the month of November 2000. The outlet near test sections N3 and N4 appears to carry a relatively large flow of drainage water. This may be a characteristic of the pavement subsurface drainage patterns. 


\section{Summary and Lessons Learned}

\section{Summary}

The pavement test track at the National Center for Asphalt Technology (NCAT) was successfully instrumented for temperature, moisture, and subsurface drainage flow. This effort was achieved through cooperation between NCAT, the Engineer Research and Development Center, and private consultants. Instrumentation hardware included 23 dataloggers spread out over the $2.7 \mathrm{~km}$ (1.7 miles) oval-shaped track and hard-wired to the on-site laboratory with $1700 \mathrm{~m}(5600 \mathrm{ft})$ of buried coaxial cable. Instruments included 184 temperature probes, 29 moisture probes, and three tipping buckets for measuring subsurface drainage flow. This report describes the hardware and documents both calibration and installation.

The temperature probes were Model 108 from Campbell Scientific, Inc. Moisture probes included CS615 probes from Campbell Scientific, Inc. and Sentry 200 probes from Troxler Electronic Laboratories, Inc., of Troxler International, Ltd. The tipping buckets were manufactured and donated by the Mississippi Department of Transportation.

Laboratory measurements verified that the temperature probes did not require individual calibrations; factory calibrations were accurate and sufficient. This study showed that the moisture probes required laboratory calibrations in the appropriate soil. While a single laboratory calibration applied to all CS615 probes, each Sentry 200 probe required an individual calibration. Slight adjustments in calibrations were necessary during probe installations and were achieved by comparing initial moisture measurements to oven-dry moisture contents for the surrounding soil.

Four temperature probes were installed in each of 46 pavement test sections. Probe depths ranged from the pavement surface to the bottom of the upper binder course. A CS615 moisture probe was installed at 23 locations, involving every second intersection between test sections. Three Sentry 200 moisture probes were installed at each of two locations. One tipping bucket was installed at each of three locations. 
A moisture probe and several temperature probes were damaged during pavement construction operations and were subsequently replaced. All probes are now performing well. The Sentry 200 probes were installed so their performance could be compared to that of the CS615 probes. So far, their performance is similar.

\section{Lessons Learned During Installation} probes.

The following lessons were learned during the installation of temperature

a. Temperature probes should not be installed near transverse joints where lifts will be sawn and cut back. Cables can become damaged during blading operations used to remove asphalt concrete.

b. Temperature probe cable will float in liquid binder. If cable is to be set in troughs, the cable must be held in place with U-shaped tacks.

c. Temperature probes must be protected from temperatures exceeding $120^{\circ} \mathrm{C}\left(250^{\circ} \mathrm{F}\right)$. In this study, they were protected with a covering of fine aggregate.

d. After filling troughs with binder, they were immediately covered with fine aggregate. This prevented tracking the binder and may have also helped to prevent bleeding.

$e$. The temperature probe that resides in a trough at the pavement surface must be covered with a material that has the same color as the asphalt concrete wearing course. In this study, samples of the mix were saved and were reheated.

The following lessons were learned during the installation of moisture probes.

a. Produce plenty of pre-sieved fill material to be used for compacting around probes, so that on-site sieving does not slow installation procedures. The sieved material should not include particles larger than the No. 4 sieve and should be the same as that used for probe calibrations.

$b$. Produce plenty of pre-sieved fill material to be used to protect buried cables. Whenever possible, cables should be protected with aggregate that does not include particles larger than the No. 8 sieve.

Following are lessons learned concerning additional instrumentation hardware.

a. During continuing pavement construction, the cables for installed probes must be protected with waterproofing and must be protected from construction traffic. In this study, the cables were threaded through PVC 
pipes, which was laid out toward the drainage ditch. If construction will include shoulder work, the pipes and any coiled cable must be clearly flagged.

$b$. To minimize the need for physical maintenance, the use of solar panels is essential. In this study, only the Sentry 200 probes were without solar energy and were entirely dependent on chemical batteries. These probes have already run out of power on two occasions.

c. Protection from electrostatic build-up is critical, especially for long "daisy-chained" dataloggers. In this study, each data logger was grounded with a 2.4-m (8-ft) copper-clad grounding rod. This protection has already saved the instrumentation system at least once. 


\section{References}

Campbell Scientific, Inc. (1997). "Model 108 Temperature Probe Instruction Manual," Logan, UT.

Campbell Scientific, Inc. (1996). "CS615 Water Content Reflectometer Instruction Manual," Version 8221-07, Logan, UT.

Troxler Electronic Laboratories, Inc., Troxler International, Ltd. (1992).

"ProbeReader Plus: Manual of Operation and Instruction," Research Triangle Park, NC. 



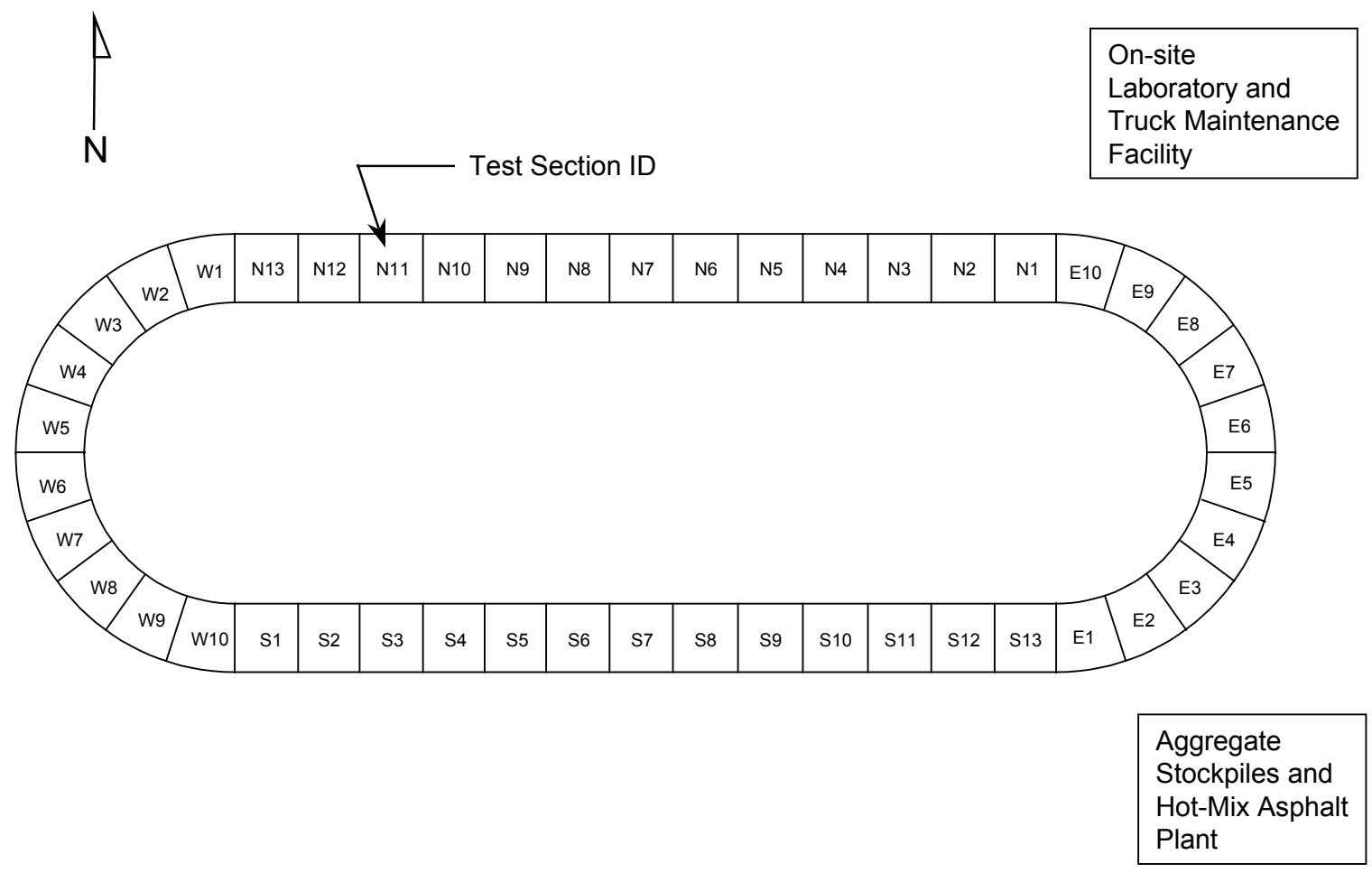

Figure 1. Track layout 


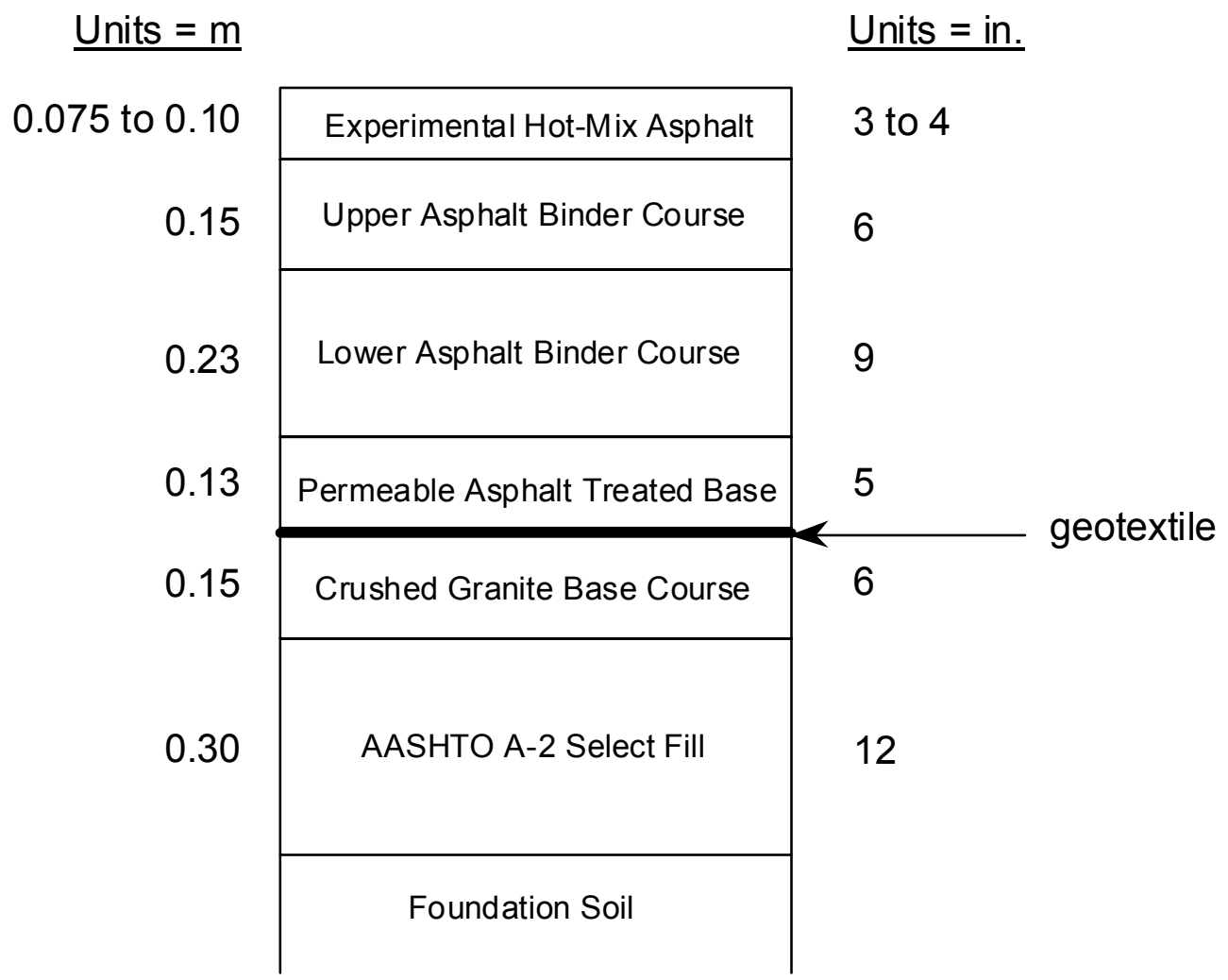

Figure 2. Typical pavement cross-section 


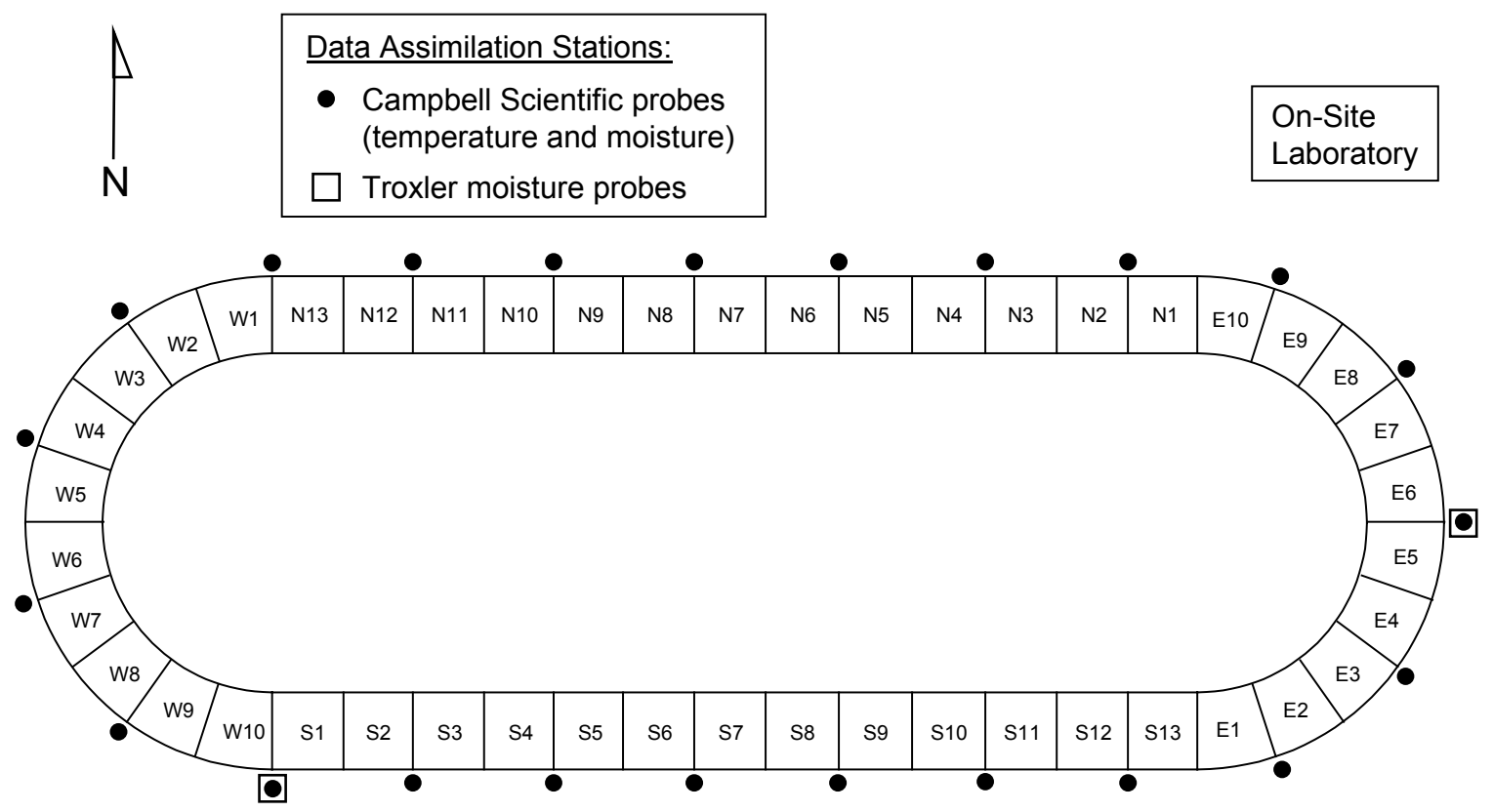

Figure 3. Locations of data assimilation stations 


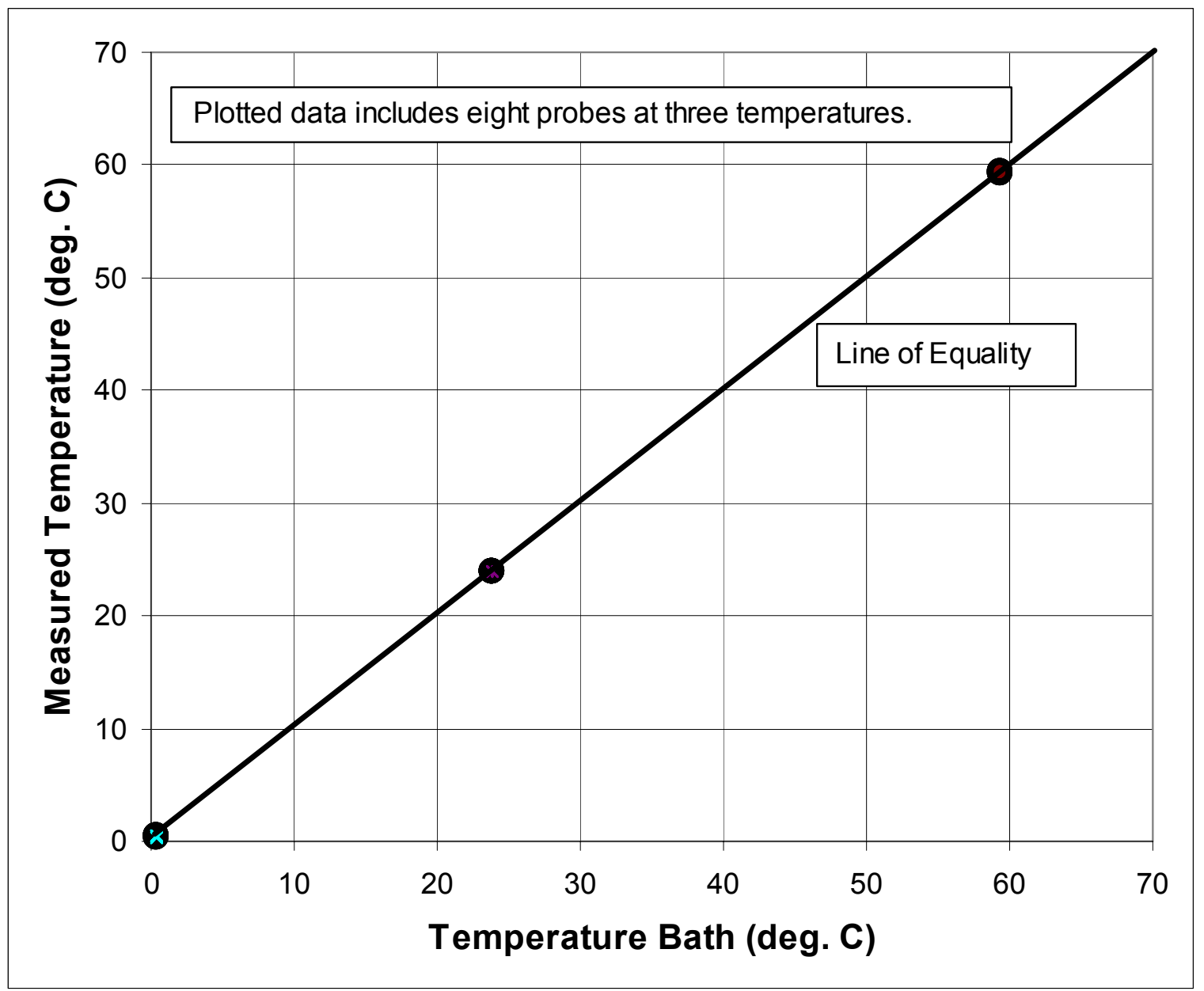

Figure 4. Verification data for Campbell scientific model 108 temperature probes $\left[F=(9 / 5)^{*}\left({ }^{\circ} \mathrm{C}\right)\right.$ $+32]$ 


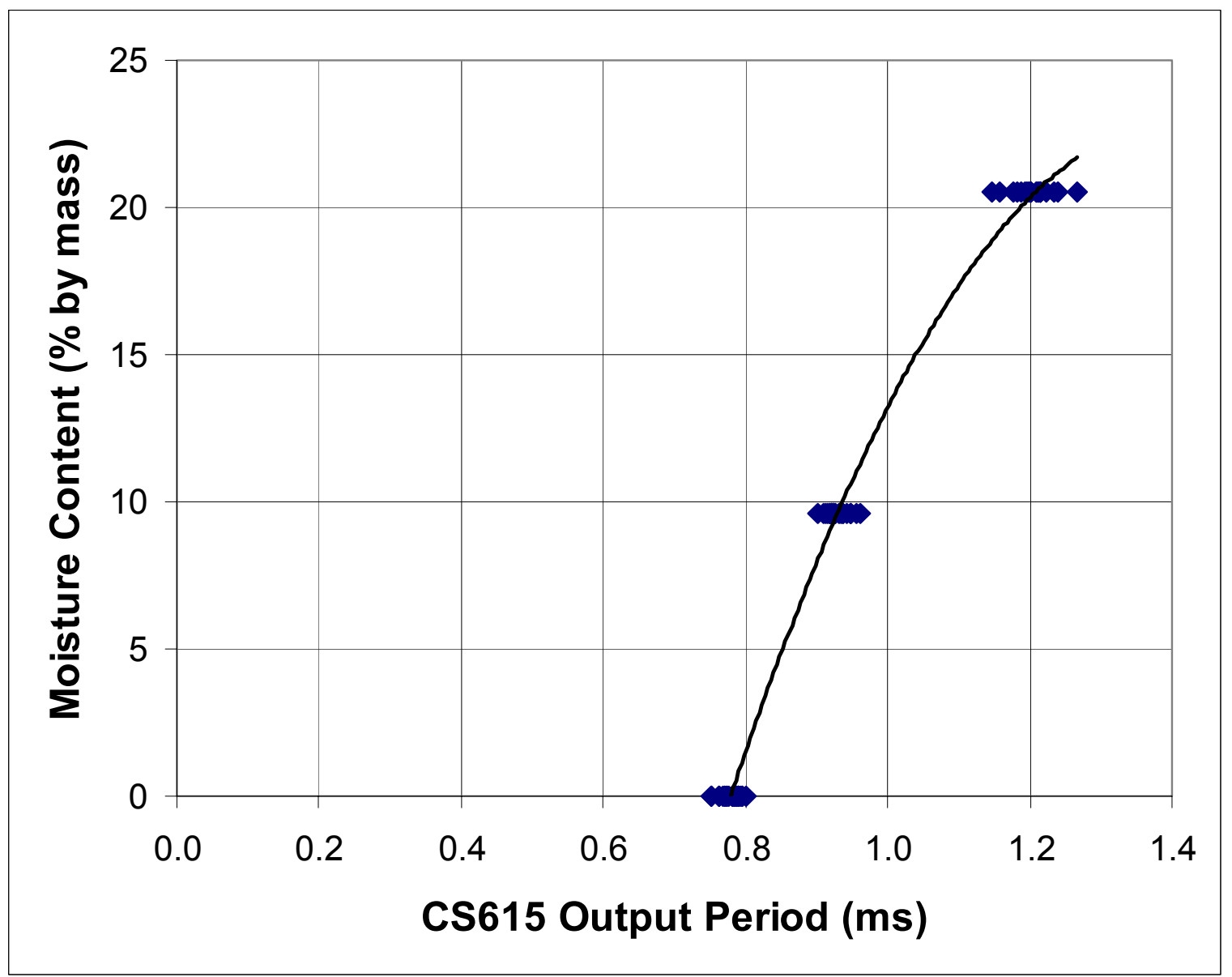

Figure 5. Calibration data and best-fit composite curve for CS615 moisture probes 


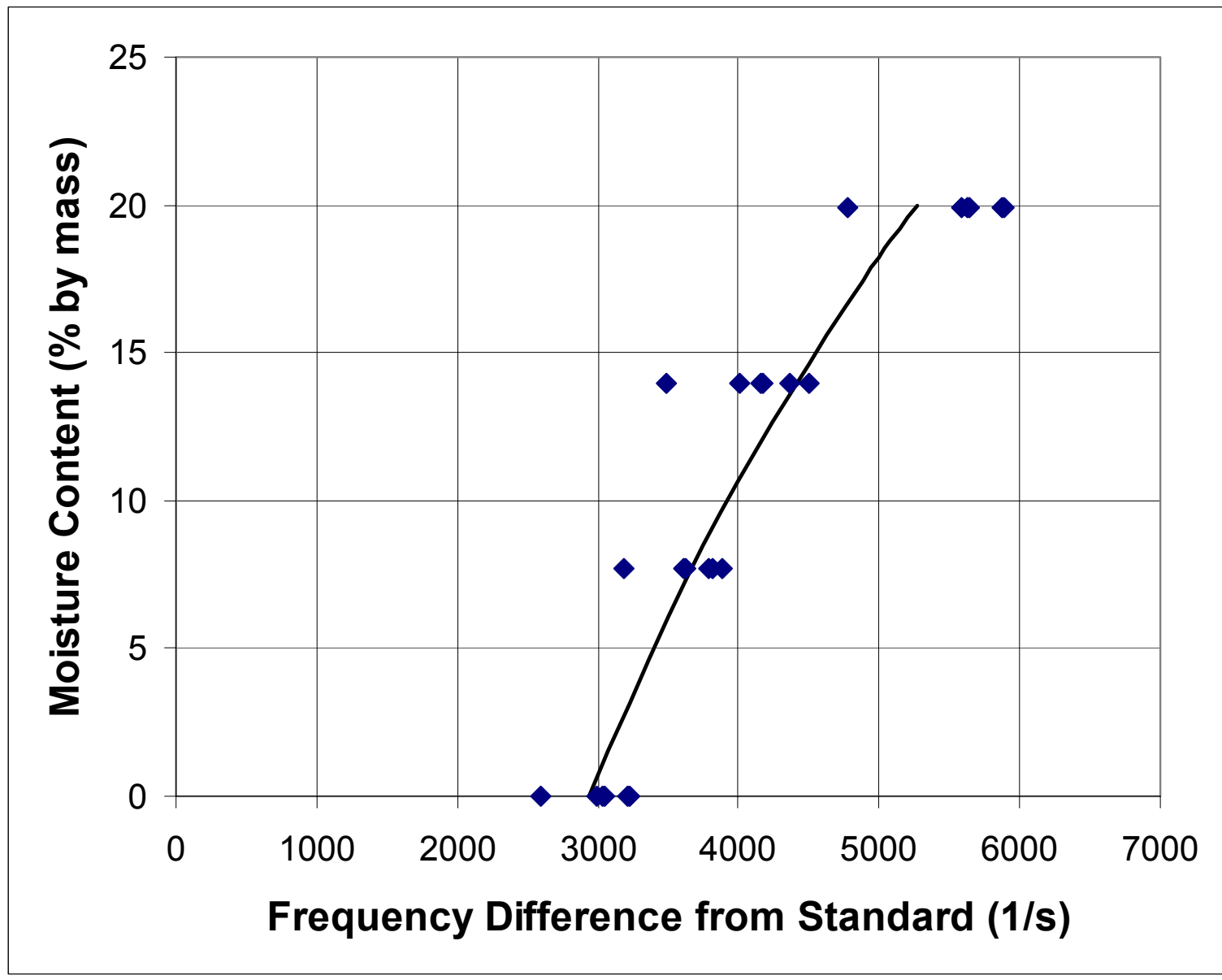

Figure 6. Calibration data and best-fit composite curve for Troxler moisture probes 


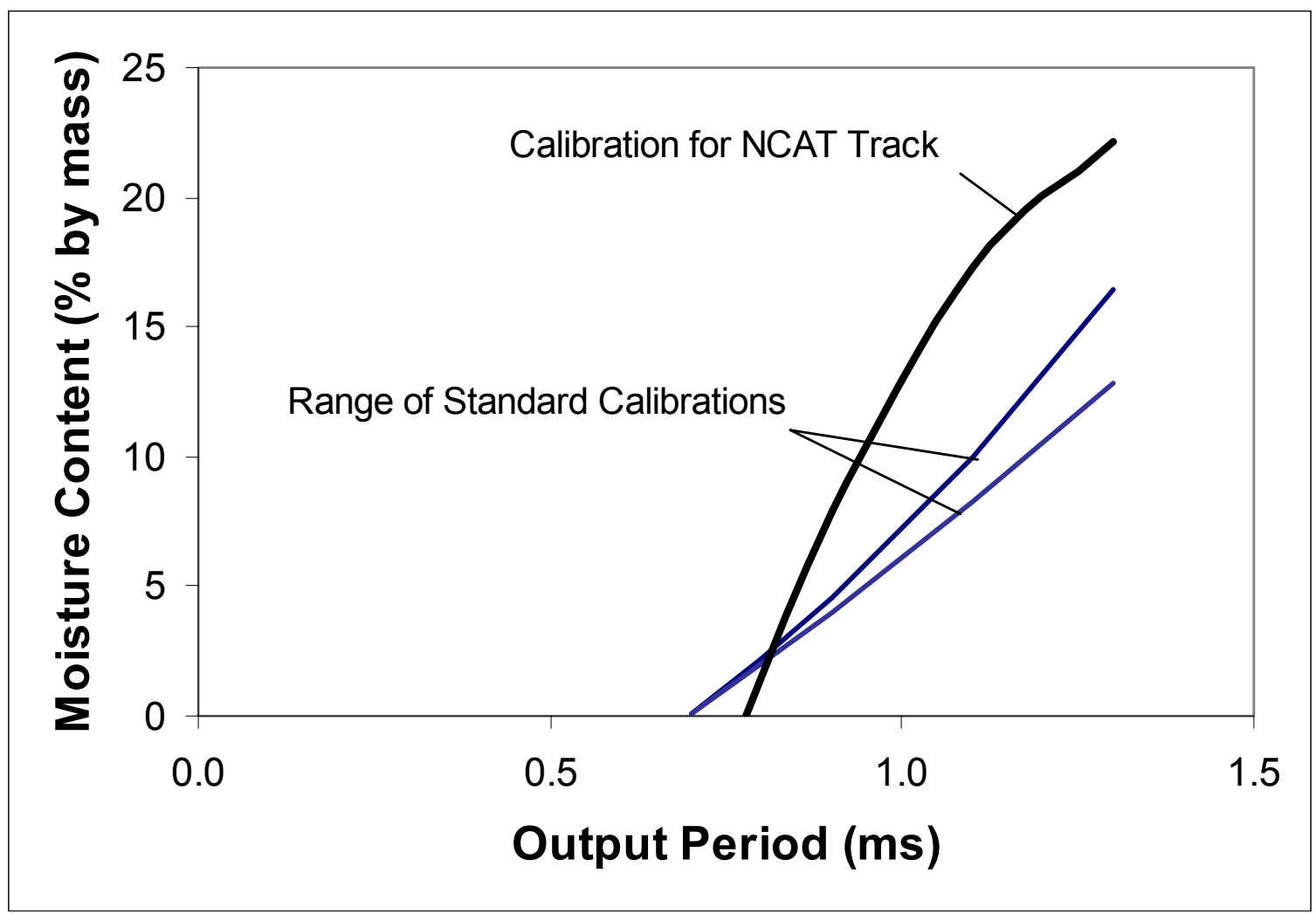

Figure 7. Comparison between the actual calibration and standard calibrations for the CS615 moisture probes 


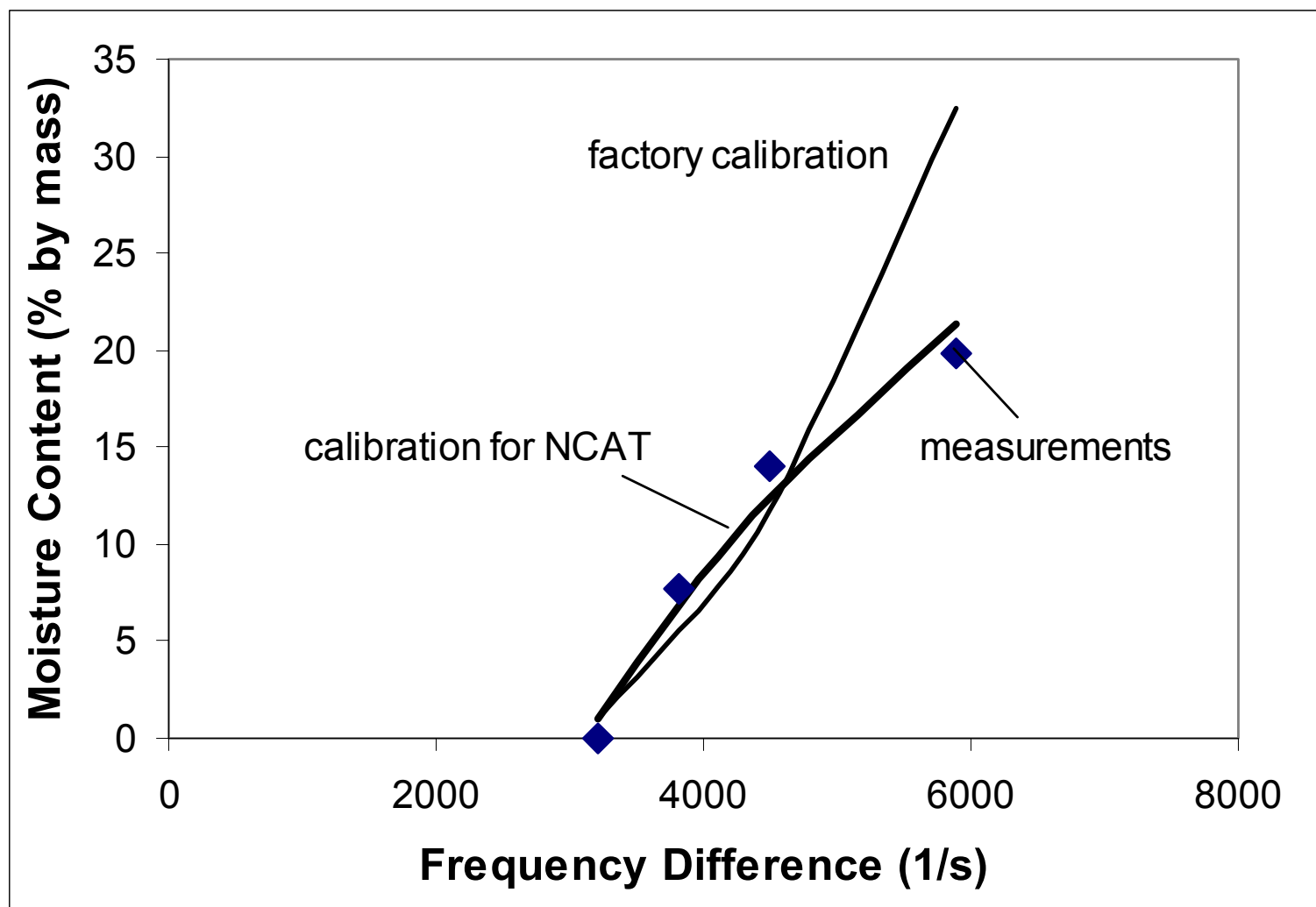

Figure 8. Comparison between the actual calibration and standard calibrations for Troxler probe No. 3 


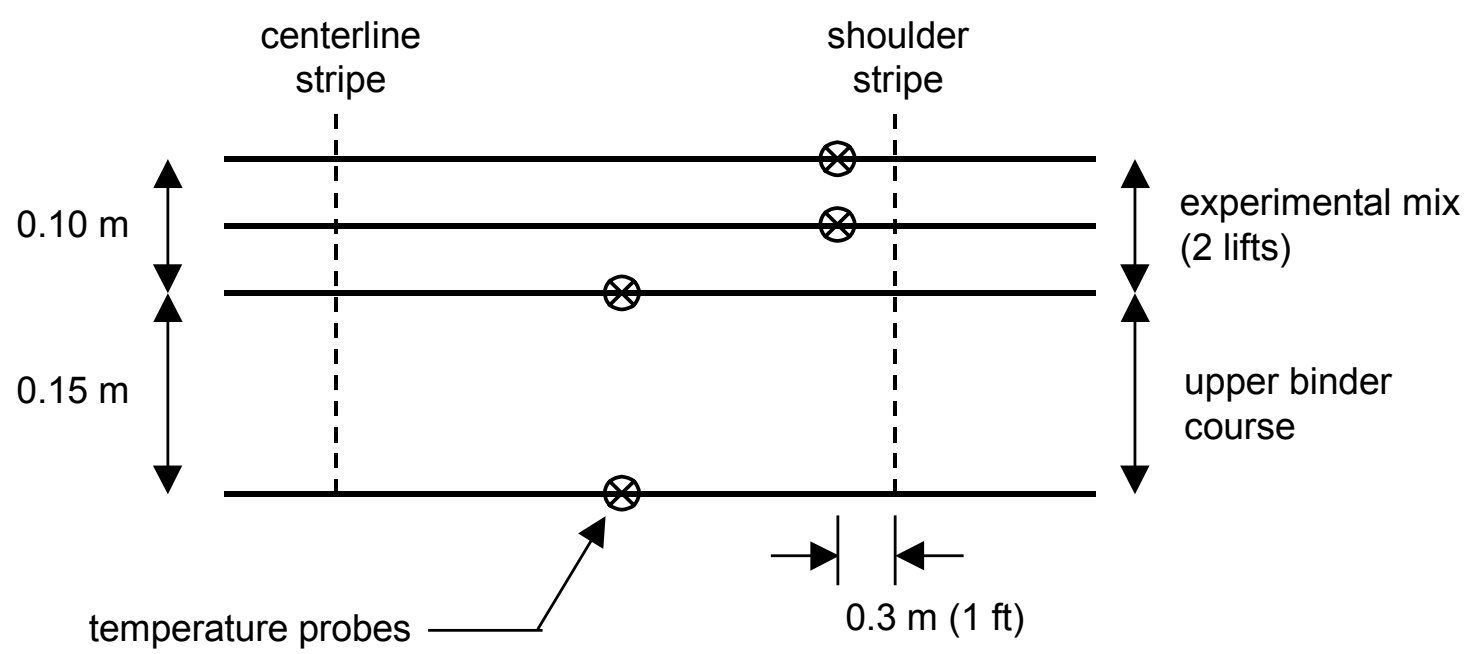

Figure 9. Position of temperature probes in the outside traffic lane

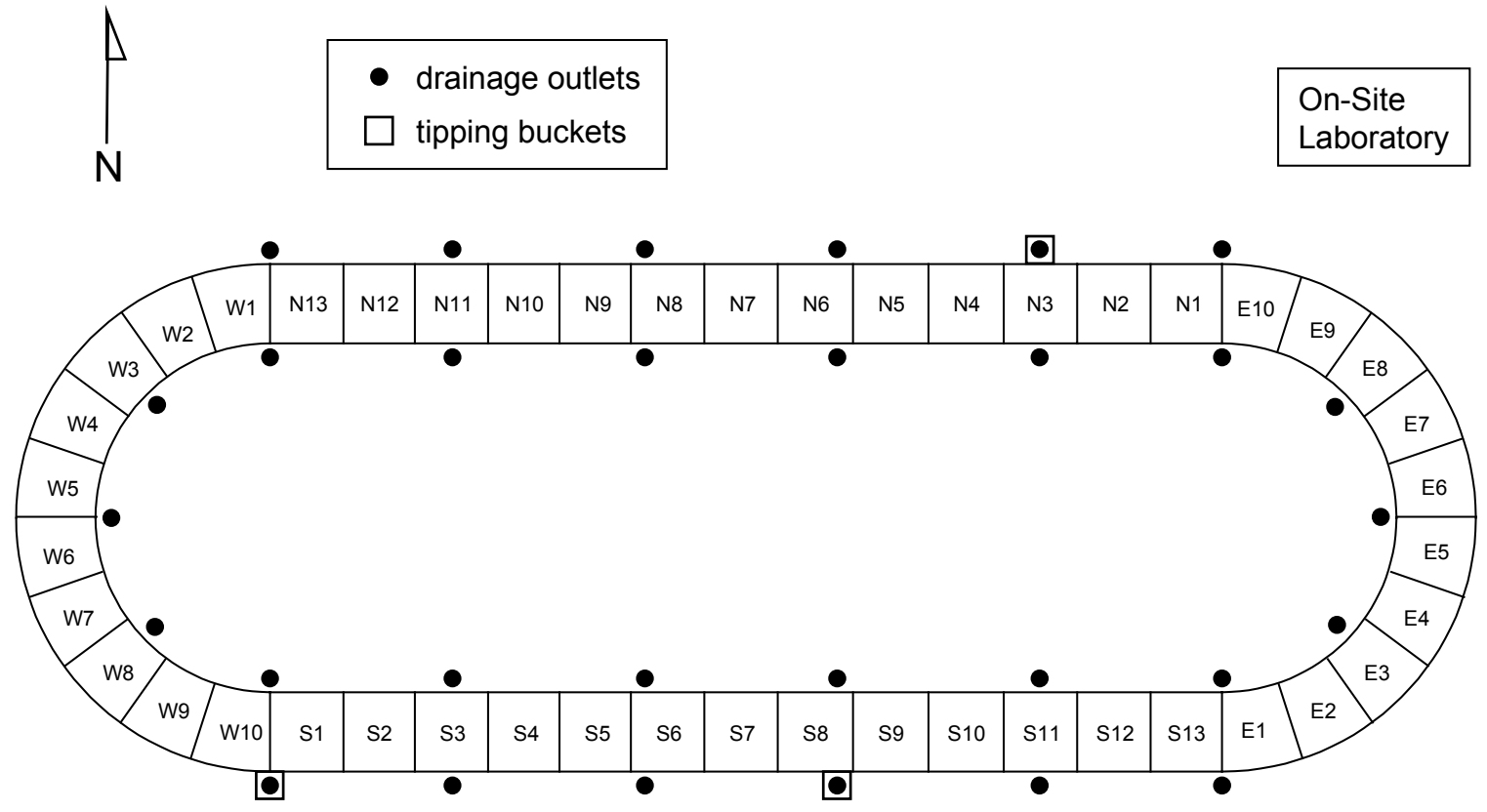

Figure 10. Layout for drainage outlets and tipping buckets 


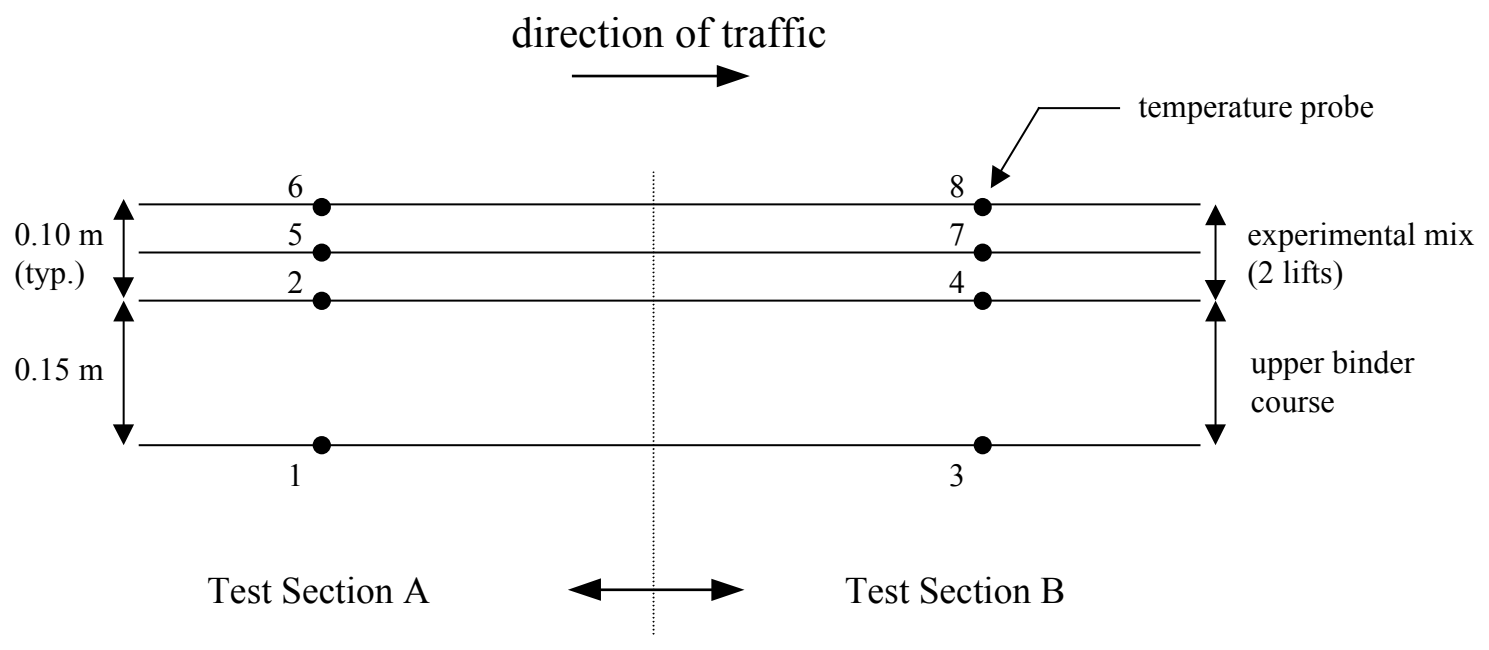

Figure 11. Order of temperature probes as written to data files

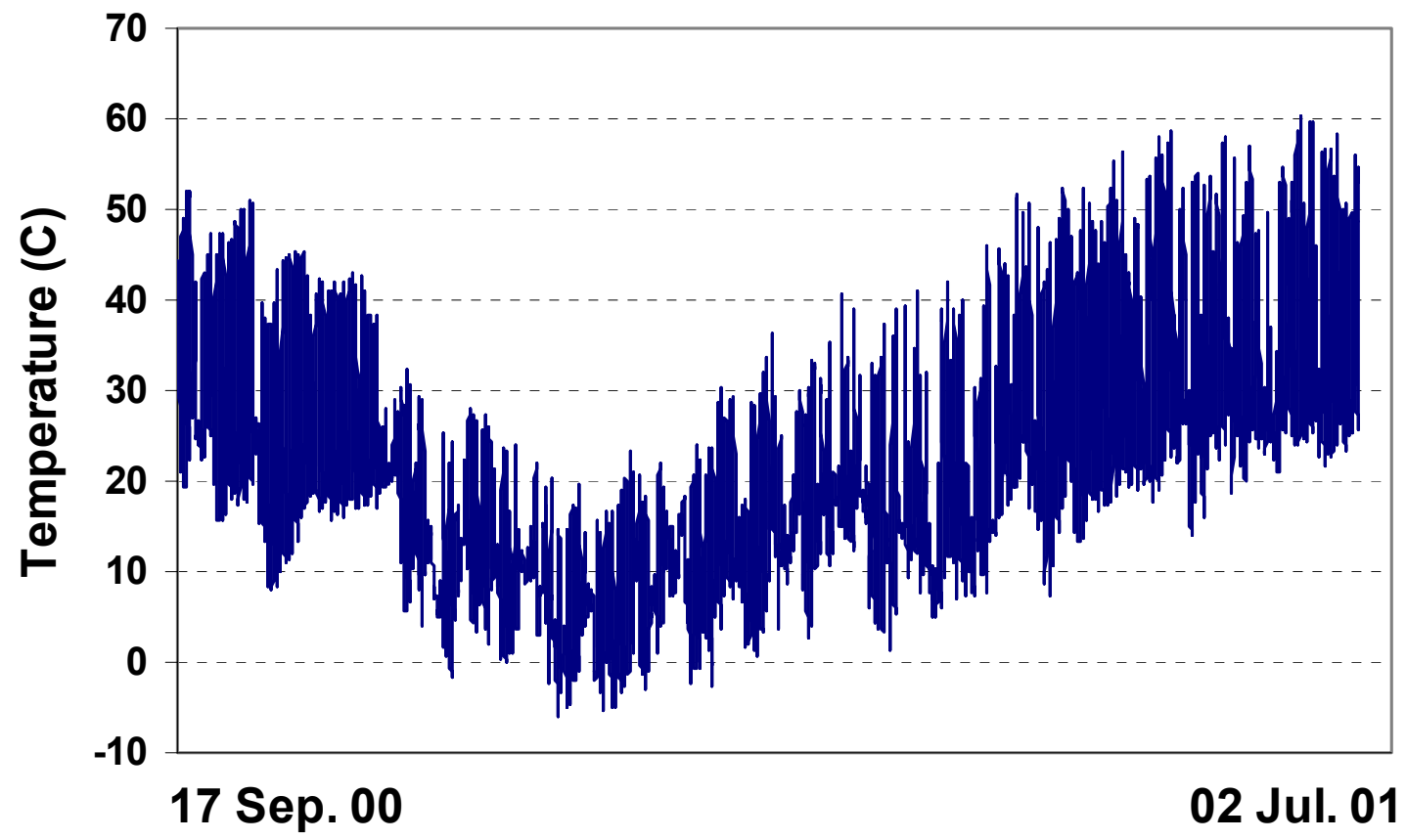

Figure 12. Temperature at pavement surface for test section S1 $[F=9 / 5(C)+32]$ 


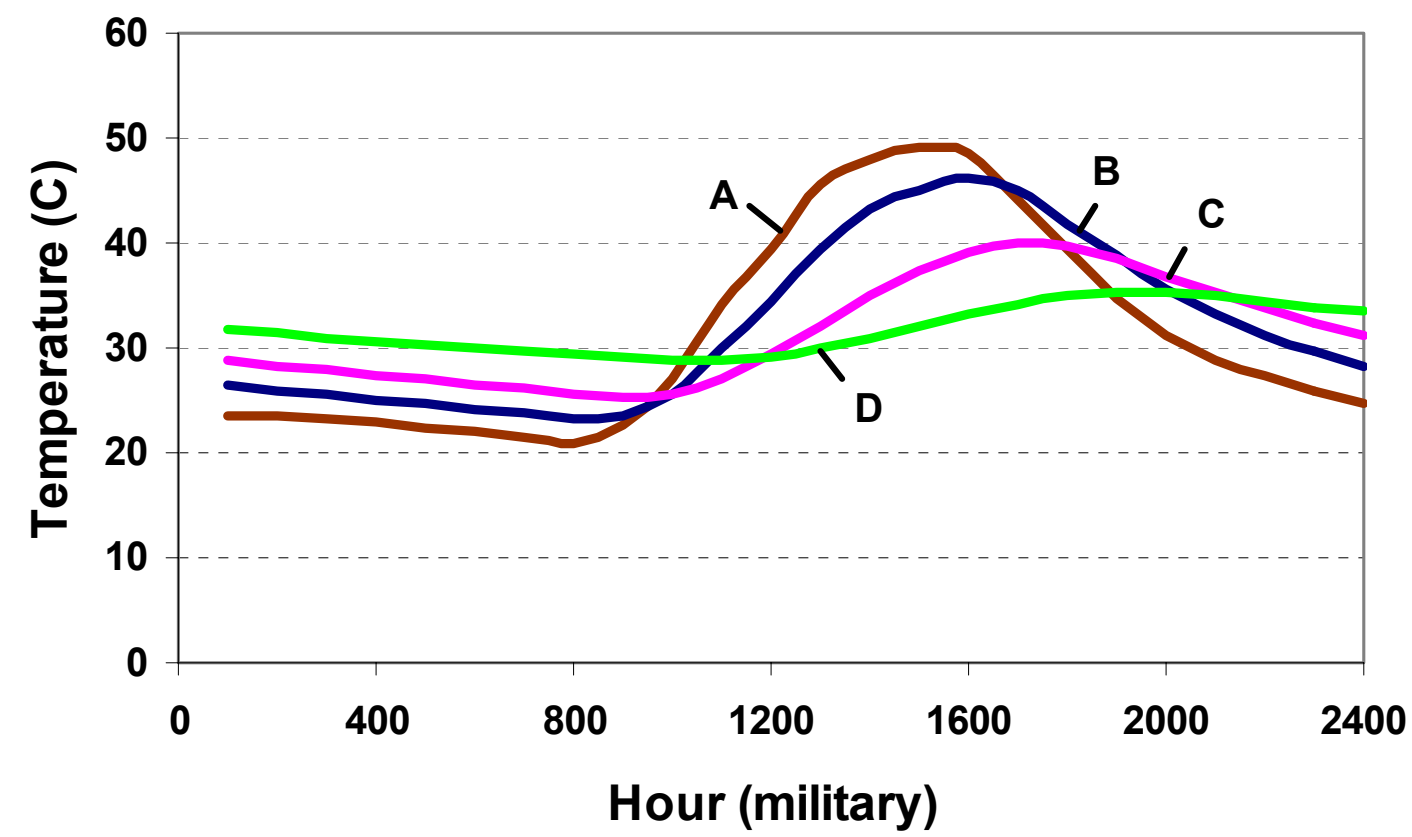

Figure 13. Temperatures for test section S1 during the date 18 September 2000 (for pavement suface ("A"), middle of experimental surface course ("B"), bottom of experimental surface course ("C"), and bottom of upper binder course ("D"))

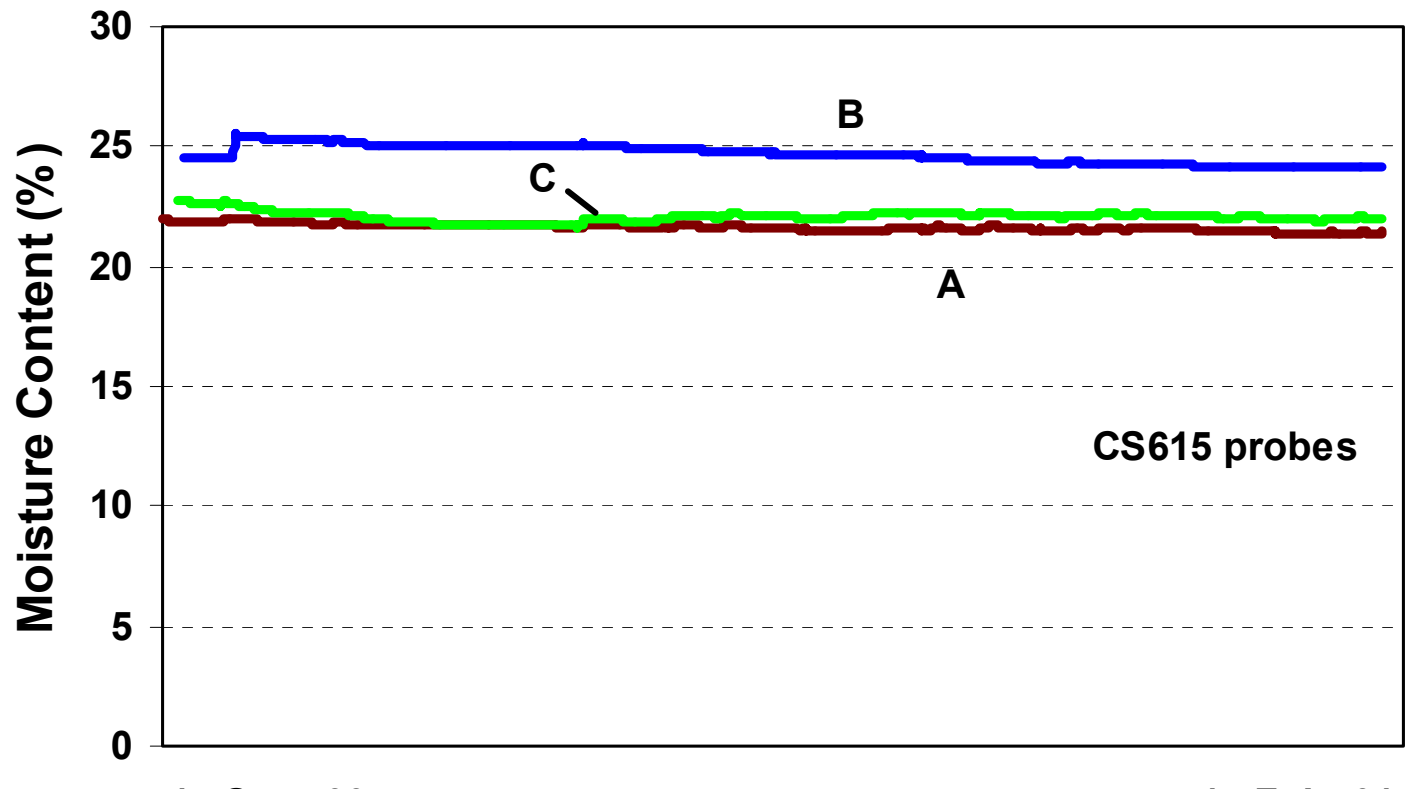

Figure 14. Moisture measurements obtained at the intersection between test sections N3 and N4 ("A"), W10 and S1 ("B"), S8 and S9 ("C") 


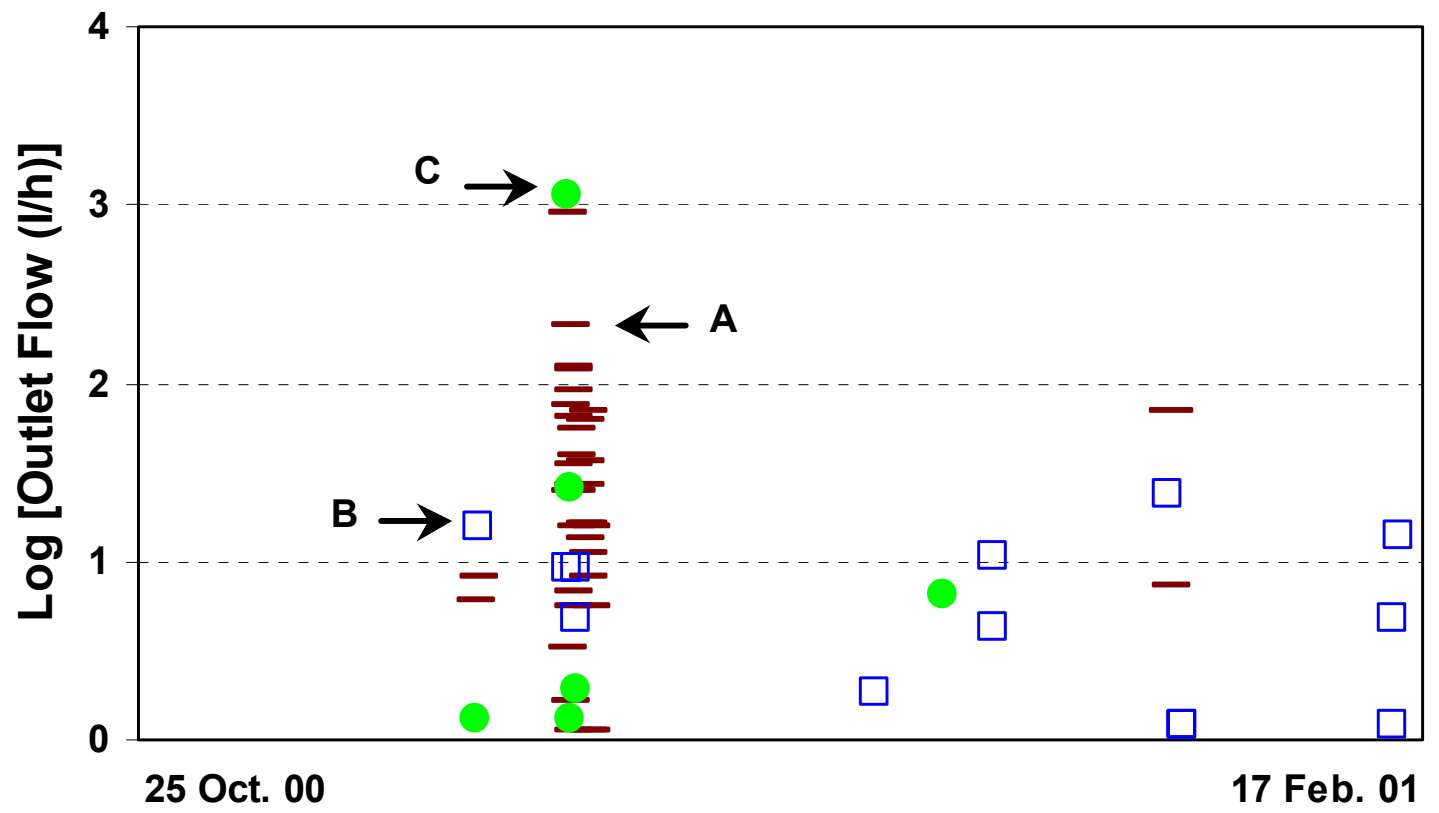

Figure 15. Drainage outlet flow measurements obtained at the intersection between test sections N3 and N4 ("A"), W10 and S1 ("B"), S8 and S9 ("C") 


\begin{tabular}{|c|c|c|c|}
\hline \multicolumn{4}{|c|}{$\begin{array}{l}\text { Table } 1 \\
\text { Average Temperatures, }{ }^{\circ} \mathrm{C}\left({ }^{\circ} \mathrm{F}\right) \text {, Measured by Campbell Scientific } \\
\text { Model } 108 \text { Probes }\end{array}$} \\
\hline \multirow[b]{2}{*}{ Probe No. } & \multicolumn{3}{|c|}{$\begin{array}{ll}\text { Temperature of } \operatorname{Immersion} B \text { Bath }{ }^{\circ} \mathrm{C}\left({ }^{\circ} \mathrm{F}\right) \\
\end{array}$} \\
\hline & $0.4444(32.80)$ & $23.83(74.90)$ & $59.33(138.8)$ \\
\hline 1 & $0.4406(32.79)$ & $23.91(75.04)$ & $59.43(139.0)$ \\
\hline 2 & $0.4189(32.75)$ & $23.88(74.99)$ & $59.37(138.9)$ \\
\hline 3 & $0.4537(32.82)$ & $23.91(75.04)$ & $59.41(138.9)$ \\
\hline$\frac{4}{4}$ & $0.4319(32.78)$ & $23.91(75.04)$ & $59.42(138.9)$ \\
\hline 5 & $0.4145(32.75)$ & $23.88(74.98)$ & $59.30(138.7)$ \\
\hline 6 & $0.3971(32.72)$ & $23.86(74.94)$ & $59.32(138.8)$ \\
\hline 7 & $0.3840(32.69)$ & $23.87(74.97)$ & $59.30(138.7)$ \\
\hline 8 & $0.3756(32.68)$ & $23.86(74.96)$ & $59.30(138.7)$ \\
\hline
\end{tabular}

\section{Table 2}

Characteristics of the Variability Associated with Model 108 Temperature Probe Verification

\begin{tabular}{||l|l|l|l|l|l||}
\hline \multirow{2}{*}{$\begin{array}{l}\text { Temperature } \\
{ }^{\circ} \mathbf{C}\left({ }^{\circ} \mathbf{F}\right)\end{array}$} & \multicolumn{2}{|c|}{ Percent Variance } & \multicolumn{3}{c||}{ Standard Deviation, ${ }^{\circ} \mathbf{C}\left({ }^{\circ} \mathrm{F}\right)$} \\
\cline { 2 - 6 } & $\begin{array}{l}\text { Between } \\
\text { Probes }\end{array}$ & $\begin{array}{l}\text { Between } \\
\text { Replicates }\end{array}$ & $\begin{array}{l}\text { Between } \\
\text { Probes }\end{array}$ & $\begin{array}{l}\text { Between } \\
\text { Replicates }\end{array}$ & Total \\
\hline \hline $0.44(32.8)$ & 83 & 17 & $0.017(0.030)$ & $0.038(0.068)$ & $0.041(0.074)$ \\
\hline $23.8(74.9)$ & 84 & 16 & $0.022(0.040)$ & $0.010(0.018)$ & $0.024(0.044)$ \\
\hline $59.3(138.8)$ & 86 & 14 & $0.056(0.100)$ & $0.023(0.041)$ & $0.060(0.108)$ \\
\hline \hline
\end{tabular}

\begin{tabular}{|c|c|c|c|c|c|}
\hline \multicolumn{6}{|c|}{$\begin{array}{l}\text { Table } 3 \\
\text { Linear Regression for Average Measured Temperature, as a } \\
\text { Function of Both Bath Temperature and Probe }\end{array}$} \\
\hline \multicolumn{6}{|c|}{$\begin{array}{l}\text { Analysis of Variance } \\
\end{array}$} \\
\hline Model & $\begin{array}{l}\text { Sum of } \\
\text { Squares }\end{array}$ & $\begin{array}{l}\text { Degrees } \\
\text { of Freedom }\end{array}$ & Mean Square & F-statistic & $\begin{array}{l}\text { Significance } \\
\text { Level }\end{array}$ \\
\hline Regression & 32750.4 & 2 & 16375.2 & 5975566 & 0.000 \\
\hline Residual & 0.06029 & 22 & 0.00274 & $\mathrm{~N} / \mathrm{A}$ & $\mathrm{N} / \mathrm{A}$ \\
\hline Total & 32750.5 & 24 & N/A & N/A & N/A \\
\hline \multicolumn{6}{|c|}{ Coefficients } \\
\hline Model & $\begin{array}{l}\text { Coefficient } \\
\text { Mean }^{1}\end{array}$ & $\begin{array}{l}\text { Coefficient } \\
\text { Std. Error } \\
\end{array}$ & $\begin{array}{l}\text { Standardized } \\
\text { Coeff. Mean }\end{array}$ & Student's t & $\begin{array}{l}\text { Significance } \\
\text { Level }\end{array}$ \\
\hline Probe No. & 0.003854 & 0.003 & n-0.001 & -1.348 & 0.191 \\
\hline Bath Temp. & 1.002 & 0.000 & 1.000 & 2559.0 & 0.000 \\
\hline
\end{tabular}




\begin{tabular}{|c|c|c|c|}
\hline \multicolumn{4}{|c|}{$\begin{array}{l}\text { Table } 4 \\
\text { Average Period (ms) for Campbell Scientific CS615 Probes During } \\
\text { Calibration }\end{array}$} \\
\hline \multirow[b]{2}{*}{ Probe No. } & \multicolumn{3}{|c|}{$\begin{array}{l}\text { Measured Soil Moisture Content (\% by mass) } \\
\end{array}$} \\
\hline & 0 & 9.6 & 20.5 \\
\hline 1 & 0.7529 & 0.9126 & 1.147 \\
\hline 2 & 0.7622 & 0.9218 & 1.175 \\
\hline 3 & 0.7531 & 0.9264 & 1.157 \\
\hline 4 & 0.7745 & 0.9315 & 1.214 \\
\hline 5 & 0.7909 & 0.9379 & 1.197 \\
\hline 6 & 0.7676 & 0.9374 & 1.201 \\
\hline 7 & 0.7928 & 0.9467 & 1.224 \\
\hline 8 & 0.7817 & 0.9490 & 1.215 \\
\hline 9 & 0.7912 & 0.9562 & 1.202 \\
\hline 10 & 0.7738 & 0.9182 & 1.181 \\
\hline 11 & 0.7825 & 0.9242 & 1.214 \\
\hline 12 & 0.7868 & 0.9165 & 1.214 \\
\hline 13 & 0.7825 & 0.9469 & 1.211 \\
\hline 14 & 0.7878 & 0.9617 & 1.202 \\
\hline 15 & 0.7627 & 0.9234 & 1.267 \\
\hline 16 & 0.7846 & 0.9267 & 1.240 \\
\hline 17 & 0.7838 & 0.9238 & 1.201 \\
\hline 18 & 0.7715 & 0.9098 & 1.194 \\
\hline 19 & 0.7904 & 0.9346 & 1.212 \\
\hline 20 & 0.7721 & 0.9024 & 1.241 \\
\hline 21 & 0.7941 & 0.9207 & 1.251 \\
\hline 22 & 0.8001 & 0.9207 & 1.240 \\
\hline 23 & 0.7865 & 0.9236 & 1.213 \\
\hline 24 & 0.7959 & 0.9414 & 1.233 \\
\hline 25 & 0.7843 & 0.9191 & 1.202 \\
\hline 26 & 0.7772 & 0.9219 & 1.212 \\
\hline
\end{tabular}




\begin{tabular}{|c|c|c|c|}
\hline \multicolumn{4}{|c|}{$\begin{array}{l}\text { Table } 5 \\
\text { Calibration Coefficients for Campbell Scientific CS615 Probes }\end{array}$} \\
\hline \multirow[b]{2}{*}{ Probe No. } & \multicolumn{3}{|c|}{ Gravimetric Moisture $=\mathrm{ax}^{2}+\mathrm{bx}+\mathrm{c}$ (see note) } \\
\hline & $\mathbf{a}$ & b & C \\
\hline 1 & -0.348 & 1.180 & -0.692 \\
\hline 2 & -0.416 & 1.301 & -0.750 \\
\hline 3 & -0.202 & 0.894 & -0.558 \\
\hline 4 & -0.515 & 1.490 & -0.845 \\
\hline 5 & -0.573 & 1.644 & -0.942 \\
\hline 6 & -0.350 & 1.163 & -0.686 \\
\hline 7 & -0.535 & 1.555 & -0.896 \\
\hline 8 & -0.380 & 1.232 & -0.731 \\
\hline 9 & -0.338 & 1.172 & -0.716 \\
\hline 10 & -0.615 & 1.706 & -0.952 \\
\hline 11 & -0.698 & 1.869 & -1.035 \\
\hline 12 & -0.876 & 2.232 & -1.214 \\
\hline 13 & -0.399 & 1.274 & -0.753 \\
\hline 14 & -0.237 & 0.967 & -0.615 \\
\hline 15 & -0.556 & 1.534 & -0.847 \\
\hline 16 & -0.719 & 1.905 & -1.053 \\
\hline 17 & -0.701 & 1.884 & -1.046 \\
\hline 18 & -0.736 & 1.931 & -1.052 \\
\hline 19 & -0.647 & 1.783 & -1.005 \\
\hline 20 & -0.873 & 2.199 & -1.177 \\
\hline 21 & -0.892 & 2.288 & -1.255 \\
\hline 22 & -1.014 & 2.541 & -1.384 \\
\hline 23 & -0.759 & 1.999 & -1.102 \\
\hline 24 & -0.656 & 1.799 & -1.017 \\
\hline 25 & -0.783 & 2.047 & -1.124 \\
\hline 26 & -0.662 & 1.787 & -0.990 \\
\hline Composite & -0.574 & 1.618 & -0.912 \\
\hline
\end{tabular}




\begin{tabular}{|c|c|c|c|c|c|}
\hline \multicolumn{6}{|c|}{$\begin{array}{l}\text { Table } 6 \\
\text { Characteristics of the Variability Associated with CS615 Probe } \\
\text { Calibration }\end{array}$} \\
\hline $\begin{array}{l}\text { Moisture } \\
\text { Content (\%) }\end{array}$ & $\begin{array}{l}\text { \% Variance } \\
\text { Between } \\
\text { Probes }\end{array}$ & $\begin{array}{l}\text { \% Variance } \\
\text { Between } \\
\text { Replicates }\end{array}$ & $\begin{array}{l}\text { CV (\%) } \\
\text { Between } \\
\text { Probes }\end{array}$ & $\begin{array}{l}\text { CV (\%) } \\
\text { Between } \\
\text { Replicates }\end{array}$ & $\begin{array}{l}\text { CV (\%) } \\
\text { Total }\end{array}$ \\
\hline 0.0 & 44 & 56 & 1.4 & 1.5 & 2.1 \\
\hline 9.6 & 31 & 69 & 1.2 & 1.8 & 2.1 \\
\hline 20.5 & 21 & 79 & 1.3 & 2.6 & 2.9 \\
\hline
\end{tabular}

\begin{tabular}{|c|c|c|c|c|}
\hline \multicolumn{5}{|c|}{$\begin{array}{l}\text { Table } 7 \\
\text { Average Frequency (1/s) for Troxler Sentry } 200 \text { Probes During } \\
\text { Calibration }\end{array}$} \\
\hline \multirow[b]{2}{*}{ Probe No. } & \multicolumn{4}{|c|}{ Measured Soil Moisture Content (\% by mass) } \\
\hline & 0 & 7.7 & 14.0 & 19.9 \\
\hline 3 & 3207 & 3821 & 4503 & 5884 \\
\hline 4 & 3046 & 3624 & 4165 & 5623 \\
\hline 5 & 3035 & 3783 & 4169 & 5591 \\
\hline 6 & 3231 & 3878 & 4366 & 5877 \\
\hline 7 & 2995 & 3606 & 4011 & 5644 \\
\hline 8 & 2599 & 3190 & 3490 & 4780 \\
\hline
\end{tabular}

\begin{tabular}{|c|c|c|c|}
\hline \multicolumn{4}{|c|}{$\begin{array}{l}\text { Table } 8 \\
\text { Calibration Coefficients for Troxler Sentry } 200 \text { Probes }\end{array}$} \\
\hline \multirow[b]{2}{*}{ Probe No. } & \multicolumn{3}{|c|}{ Gravimetric Moisture $=(1 / \mathrm{C} 1) \ln [(\mathrm{x}-\mathrm{C} 2) / \mathrm{C} 0]$ (see note) } \\
\hline & $\mathrm{CO}$ & C1 & $\mathrm{C} 2$ \\
\hline 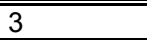 & 3114 & 0.0298 & 0 \\
\hline 4 & 2946 & 0.0296 & 0 \\
\hline 5 & 2990 & 0.0291 & 0 \\
\hline 6 & 3142 & 0.0287 & 0 \\
\hline 7 & 2893 & 0.0300 & 0 \\
\hline 8 & 2542 & 0.0288 & 0 \\
\hline Composite & 2931 & 0.0293 & 0 \\
\hline \multicolumn{4}{|c|}{$\begin{array}{l}\text { Notes: Gravimetric moisture content is as a percent. The independent variable }(x) \text { is the } \\
\text { measured frequency difference }(1 / \mathrm{s}) \text {, relative to a standard. Composite parameters were obtained } \\
\text { by using average data for all probes for each of three moisture contents. }\end{array}$} \\
\hline
\end{tabular}

\begin{tabular}{|c|c|c|c|c|c|}
\hline \multicolumn{6}{|c|}{$\begin{array}{l}\text { Table } 9 \\
\text { Characteristics of the Variability Associated with Troxler Probe } \\
\text { Calibration }\end{array}$} \\
\hline $\begin{array}{l}\text { Moisture } \\
\text { Content (\%) }\end{array}$ & $\begin{array}{l}\% \text { Variance } \\
\text { Between } \\
\text { Probes } \\
\end{array}$ & $\begin{array}{l}\% \text { Variance } \\
\text { Between } \\
\text { Replicates } \\
\end{array}$ & $\begin{array}{l}\text { CV }(\%) \\
\text { Between } \\
\text { Probes } \\
\end{array}$ & $\begin{array}{l}\text { CV (\%) } \\
\text { Between } \\
\text { Replicates } \\
\end{array}$ & $\begin{array}{l}\text { CV (\%) } \\
\text { Total } \\
\end{array}$ \\
\hline 0.0 & $>99$ & $<1$ & 7.5 & 0.02 & 7.5 \\
\hline 7.7 & $>99$ & $<1$ & 6.9 & 0.05 & 6.9 \\
\hline 14 & $>99$ & $<1$ & 8.6 & 0.02 & 8.6 \\
\hline 19.9 & $>99$ & $<1$ & 7.3 & 0.02 & 7.3 \\
\hline
\end{tabular}




\begin{tabular}{|l|l||l||}
\hline \hline Table 10 \\
Installation Data for Campbell Scientific CS615 Probes \\
\hline
\end{tabular}

\begin{tabular}{|c|c|c|c|c|c|}
\hline \multicolumn{6}{|c|}{$\begin{array}{l}\text { Table } 11 \\
\text { Installation Data for Troxler Sentry } 200 \text { Probes }\end{array}$} \\
\hline \multirow[b]{2}{*}{ Test Section } & \multirow[b]{2}{*}{ Probe No. } & \multirow{2}{*}{$\begin{array}{l}\text { Average } \\
\text { Reading (1/s) }\end{array}$} & \multicolumn{3}{|c|}{ Moisture Contents (\% by mass) } \\
\hline & & & (1) & (2) & (3) \\
\hline \multirow{3}{*}{ W10_S1 } & 3 & 4761 & 14.2 & \multirow{3}{*}{11.6} & -2.6 \\
\hline & 4 & 4153 & 11.6 & & 0.0 \\
\hline & 5 & 4374 & 13.1 & & -1.5 \\
\hline \multirow{3}{*}{ E5_E6 } & 6 & 4434 & 12.0 & \multirow{3}{*}{8.7} & -3.3 \\
\hline & 7 & 4224 & 12.6 & & -3.9 \\
\hline & 8 & 3658 & 12.6 & & -3.9 \\
\hline Average & & & 12.7 & 10.2 & -2.5 \\
\hline \multicolumn{6}{|c|}{$\begin{array}{l}\text { (1) Estimated by probe after installation using the calibration parameters that were developed fo } \\
\text { each individual probe. } \\
\text { (2) Measured oven-dry moisture of scalped select fill used to cover probe. } \\
\text { (3) Measured oven-dry moisture (2) minus that estimated by probe (1). } \\
\text { Note: Probes } 3 \text { and } 6 \text { were installed at intersection between the outer traffic lane and the } \\
\text { shoulder. All other probes were installed at the center of the outer traffic lane. }\end{array}$} \\
\hline
\end{tabular}




\begin{tabular}{|c|c|c|c|}
\hline \multicolumn{4}{|c|}{$\begin{array}{l}\text { Table } 12 \\
\text { Final Adjusted Moisture Content Estimates at the Time of } \\
\text { Installing Campbell Scientific CS615 Probes }\end{array}$} \\
\hline Test Section & Probe No. & $\begin{array}{l}\text { Average } \\
\text { Reading (ms) }\end{array}$ & $\begin{array}{l}\text { Moisture Content } \\
\text { (\% by mass) }\end{array}$ \\
\hline N1_N2 & 26 & 0.8962 & 10.6 \\
\hline N3_N4 & 2 & 0.8954 & 10.6 \\
\hline N5_N6 & 3 & 0.8653 & 8.7 \\
\hline N7_N8 & 4 & 0.8887 & 10.2 \\
\hline N9_N10 & 5 & 0.9098 & 11.4 \\
\hline N11_N12 & 6 & 0.8345 & 6.7 \\
\hline N13_W1 & 7 & 0.8456 & 7.5 \\
\hline W2_W3 & 8 & 0.8629 & 8.6 \\
\hline W4_W5 & 9 & 0.8481 & 7.6 \\
\hline W6_W7 & 10 & 0.8083 & 5.0 \\
\hline W8_W9 & 11 & 0.8373 & 6.9 \\
\hline W10_S1 & 12 & 0.8941 & 10.5 \\
\hline S2_S3 & 13 & 0.8845 & 9.9 \\
\hline S4_S5 & 14 & 0.8919 & 10.3 \\
\hline S6_S7 & 15 & 0.8520 & 7.9 \\
\hline S8_S9 & 16 & 0.8512 & 7.8 \\
\hline S10_S11 & 18 & 0.8305 & 6.5 \\
\hline S12_S13 & 19 & 0.8681 & 8.9 \\
\hline E1_E2 & 20 & 0.8697 & 9.0 \\
\hline E3_E4 & 21 & 0.8498 & 7.7 \\
\hline E5_E6 & 22 & 0.8735 & 9.2 \\
\hline E7_E8 & 23 & 0.8551 & 8.1 \\
\hline E9_E10 & 25 & 0.9101 & 11.4 \\
\hline Average & & & 8.7 \\
\hline Standard Deviation & & & 1.69 \\
\hline \multicolumn{4}{|c|}{$\begin{array}{l}\text { Notes: } \\
\text { (1) The final adjusted equation for estimating moisture content is: } \\
\qquad \begin{aligned} y & =-0.574 x^{2}+1.618 x-0.883, \text { where } \\
y & =\text { moisture content as a decimal and } \\
x & =\text { measured period ( } \mathrm{ms} \text { ) }\end{aligned} \\
\text { (2) All probes were installed at the center of the outer traffic lane. }\end{array}$} \\
\hline
\end{tabular}

\begin{tabular}{|c|c|c|c|c|}
\hline \multicolumn{5}{|c|}{$\begin{array}{l}\text { Table } 13 \\
\text { Final Adjusted Calibration Coefficients for Troxler Sentry } 200 \\
\text { Probes }\end{array}$} \\
\hline \multirow[b]{2}{*}{ Test Section } & \multirow[b]{2}{*}{ Probe No. } & \multicolumn{3}{|c|}{$\begin{array}{c}\text { Gravimetric Moisture }=(1 / \mathrm{C} 1) \operatorname{In}[(\mathrm{x}-\mathrm{C} 2) / \mathrm{C} 0] \\
\text { (see note) }\end{array}$} \\
\hline & & $\mathrm{CO}$ & C1 & $\mathrm{C2}$ \\
\hline \multirow{3}{*}{ W10_S1 } & 3 & 3355 & 0.0298 & 0 \\
\hline & 4 & 3172 & 0.0296 & 0 \\
\hline & 5 & 3216 & 0.0291 & 0 \\
\hline \multirow{3}{*}{ E5_E6 } & 6 & 3376 & 0.0287 & 0 \\
\hline & 7 & 3118 & 0.0300 & 0 \\
\hline & 8 & 2732 & 0.0288 & 0 \\
\hline
\end{tabular}




\begin{tabular}{|c|c|c|c|}
\hline \multicolumn{4}{|c|}{$\begin{array}{l}\text { Table } 14 \\
\text { Final Adjusted Moisture Content Estimates at the Time of } \\
\text { Installing Troxler Sentry } 200 \text { Probes }\end{array}$} \\
\hline Station & Probe No. & $\begin{array}{l}\text { Average } \\
\text { Reading (1/s) }\end{array}$ & $\begin{array}{l}\text { Moisture Content } \\
\text { (\% by mass) }\end{array}$ \\
\hline \multirow{3}{*}{ W10_S1 } & 3 & 4761 & 11.7 \\
\hline & 4 & 4153 & 9.1 \\
\hline & 5 & 4374 & 10.6 \\
\hline \multirow{3}{*}{ E5_E6 } & 6 & 4434 & 9.5 \\
\hline & 7 & 4224 & 10.1 \\
\hline & 8 & 3658 & 10.1 \\
\hline Average & & & 10.2 \\
\hline Standard Deviation & & & 0.92 \\
\hline
\end{tabular}

\begin{tabular}{|c|c|c|c|c|c|}
\hline \multicolumn{6}{|c|}{$\begin{array}{l}\text { Table } 15 \\
\text { Moisture Measurements Obtained by the CS615 Probes and } \\
\text { Collected Using a Hand-Held Keyboard }\end{array}$} \\
\hline \multirow[b]{2}{*}{ Test Section } & \multicolumn{5}{|c|}{ Moisture Content (\% by mass) } \\
\hline & 15 Nov. 1999 & 28 Feb. 2000 & 22 Mar. 2000 & 21 Aug. 2000 & 30 Aug. 2000 \\
\hline N1_N2 & 10.6 & 21.3 & 21.3 & 20.9 & 20.9 \\
\hline N3 N4 & 10.6 & 22.2 & 22.1 & 22.1 & 22.0 \\
\hline N5_N6 & 8.7 & 20.7 & 20.7 & 21.2 & 21.2 \\
\hline N7_N8 & 10.2 & 22.0 & 22.0 & 22.3 & 22.3 \\
\hline N9_N10 & 11.4 & 22.7 & 22.7 & 23.2 & 23.1 \\
\hline N11_N12 & 6.7 & 22.4 & 22.3 & 22.5 & 22.5 \\
\hline N13_W1 & 7.5 & 22.4 & 22.0 & 21.9 & 21.9 \\
\hline W2_W3 & 8.6 & 22.0 & 19.8 & 19.4 & 19.5 \\
\hline W4_W5 & 7.6 & 23.0 & 23.2 & 24.9 & 24.5 \\
\hline W6_W7 & 5.0 & 22.5 & 22.6 & 23.1 & 23.1 \\
\hline W8_W9 & 6.9 & 22.3 & 22.4 & 24.8 & 24.9 \\
\hline W10_S1 & 10.5 & 24.8 & 24.9 & 24.8 & 24.8 \\
\hline S2_S3 & 9.9 & 24.4 & 24.6 & 24.8 & no data \\
\hline S4_S5 & 10.3 & 23.3 & 23.3 & 25.6 & no data \\
\hline S6_S7 & 7.9 & 22.9 & 23.0 & 24.9 & no data \\
\hline S8_S9 & 7.8 & 21.4 & 21.4 & 23.8 & 23.6 \\
\hline S10_S11 & 6.5 & 22.6 & 22.7 & 23.8 & 23.7 \\
\hline S12_S13 & 8.9 & 23.4 & 23.5 & 23.6 & 23.6 \\
\hline E1_E2 & 9.0 & 23.9 & 24.3 & 25.4 & 25.4 \\
\hline E3 E4 & 7.7 & 23.2 & 23.5 & 24.9 & no data \\
\hline E5_E6 & 9.2 & 21.8 & 21.8 & 21.3 & 21.3 \\
\hline E7_E8 & 8.1 & 22.3 & 22.2 & 21.9 & 21.8 \\
\hline E9_E10 & 11.4 & 24.3 & 24.4 & 24.8 & no data \\
\hline Average & 8.7 & 22.7 & 22.6 & 23.3 & 22.8 \\
\hline $\begin{array}{l}\text { Standard } \\
\text { Deviation }\end{array}$ & 1.69 & 1.02 & 1.24 & 1.69 & 1.58 \\
\hline
\end{tabular}




\begin{tabular}{|c|c|c|c|c|}
\hline \multicolumn{5}{|c|}{$\begin{array}{l}\text { Table } 16 \\
\text { Moisture Measurements Obtained by the Sentry } 200 \text { Probes and } \\
\text { Collected Using a Hand-Held Data Acquisition Computer }\end{array}$} \\
\hline \multirow{2}{*}{ Station } & \multicolumn{4}{|c|}{$\begin{array}{ll}\text { Moisture Content (\% by mass) } \\
\end{array}$} \\
\hline & 15 Nov. 1999 & 22 Mar. 2000 & 17 Sep. 2000 & 18 Feb. 2001 \\
\hline \multirow{3}{*}{ W10_S1 } & 11.7 & 21.8 & 22.5 & 20.7 \\
\hline & 9.1 & 20.8 & 21.0 & 20.2 \\
\hline & 10.6 & 21.9 & 22.2 & 20.9 \\
\hline \multirow{3}{*}{ E5_E6 } & 9.5 & 20.6 & 20.1 & 21.0 \\
\hline & 10.1 & 20.2 & no data* & 20.9 \\
\hline & 10.1 & 21.4 & no data* & 21.6 \\
\hline Average & 10.2 & 21.1 & 21.5 & 20.9 \\
\hline $\begin{array}{l}\text { Standard } \\
\text { Deviation }\end{array}$ & 0.92 & 0.69 & 1.12 & 0.47 \\
\hline
\end{tabular}




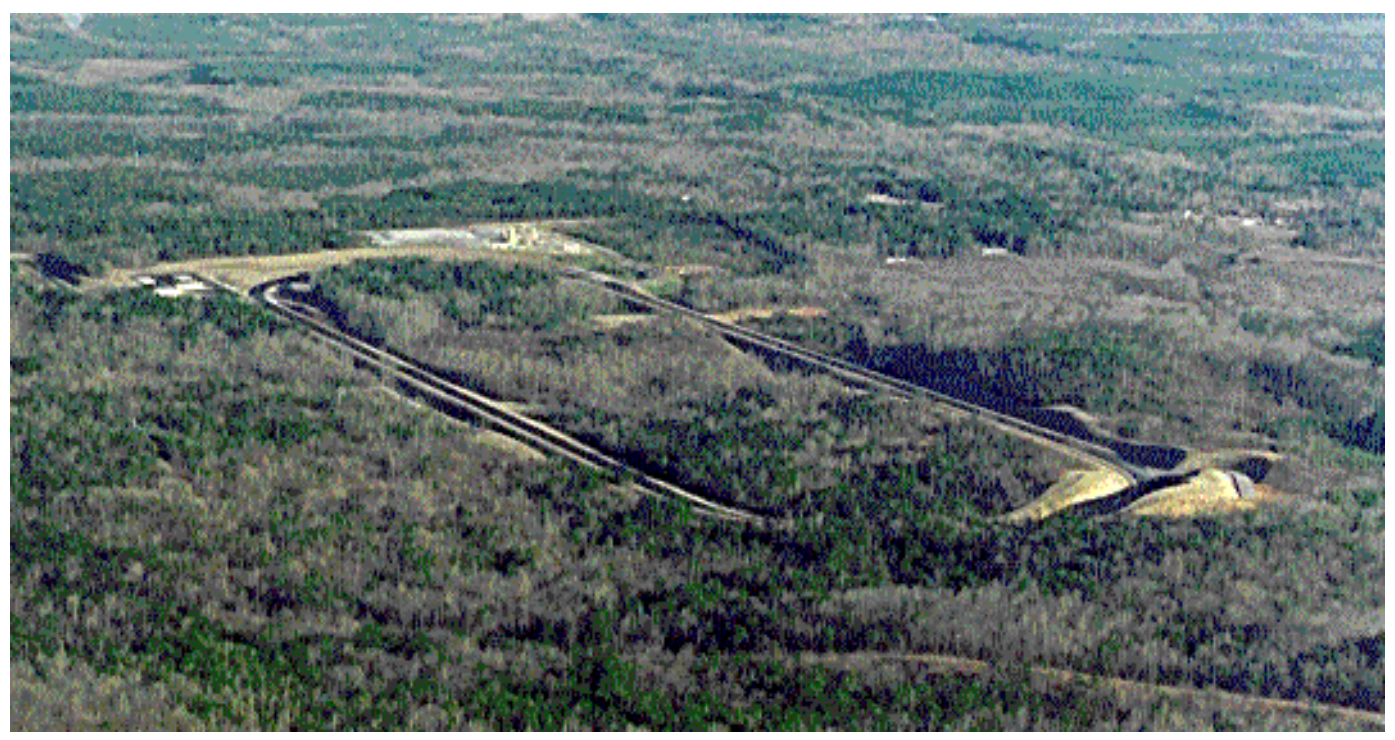

Photo 1. Aerial view of the NCAT test track

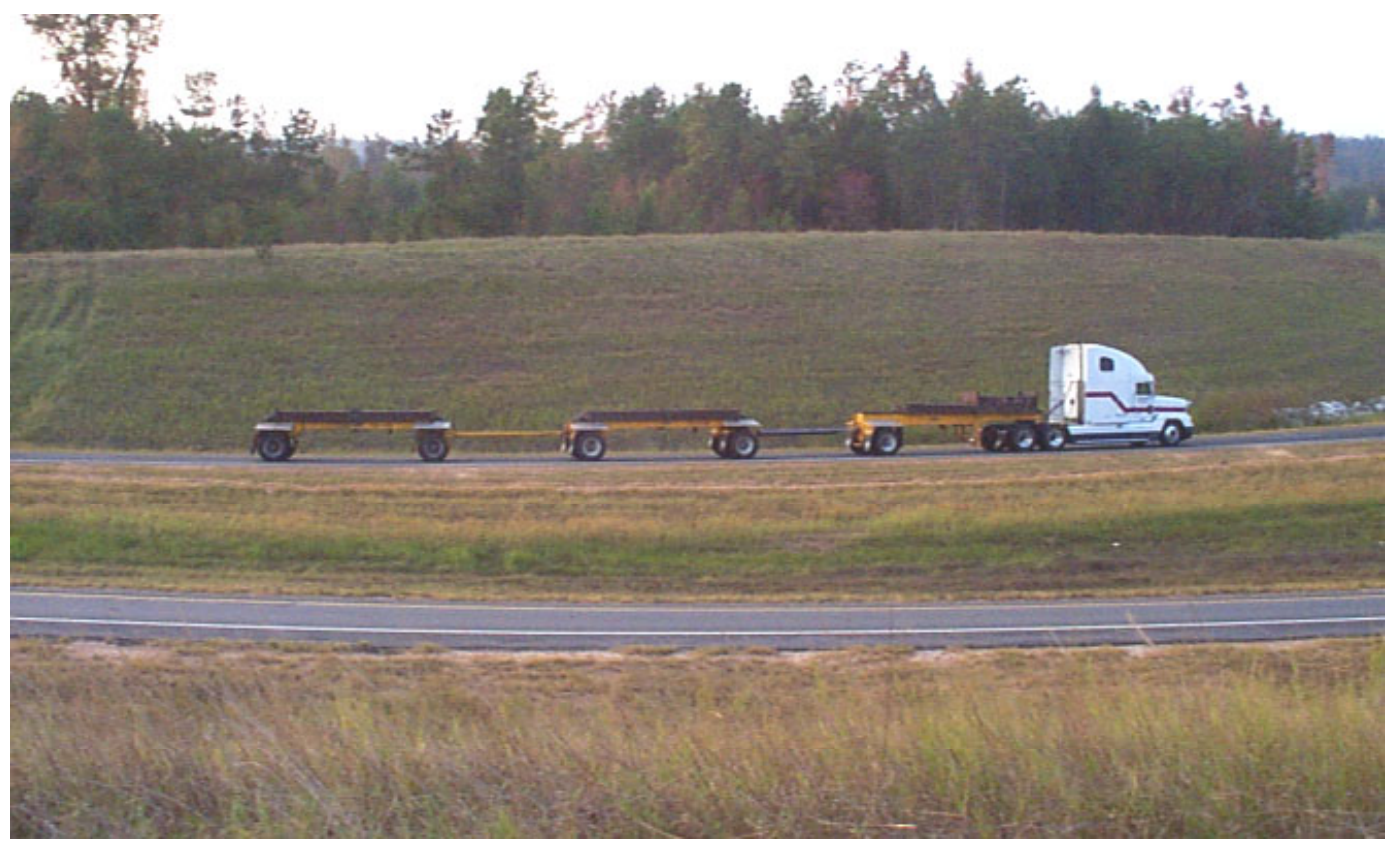

Photo 2. Manually-driven triple-trailer truck 


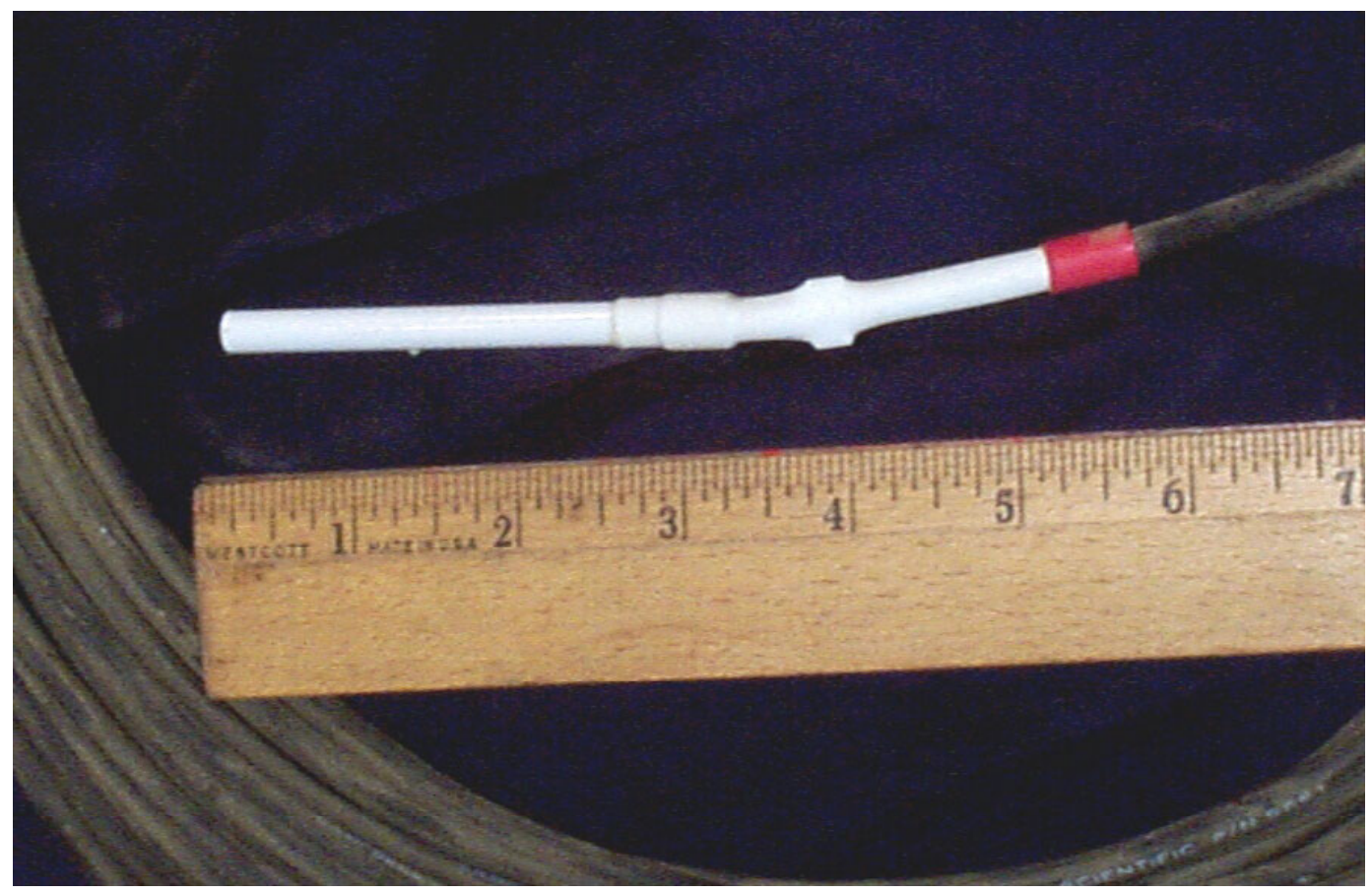

Photo 3. Temperature probe, Campbell Scientific Model 108

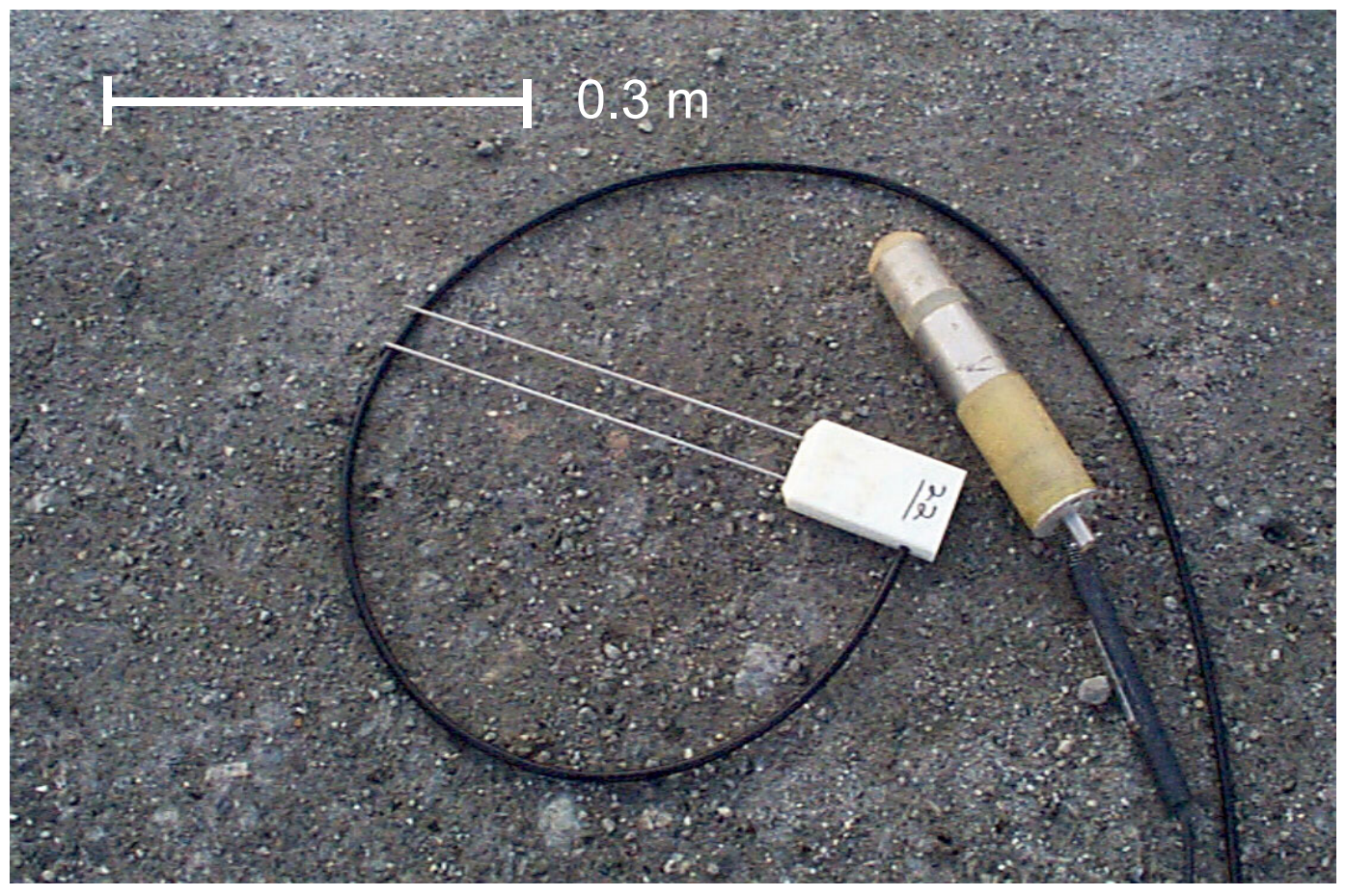

Photo 4. Soil moisture probes, CS615 on left and Sentry 200 on right 


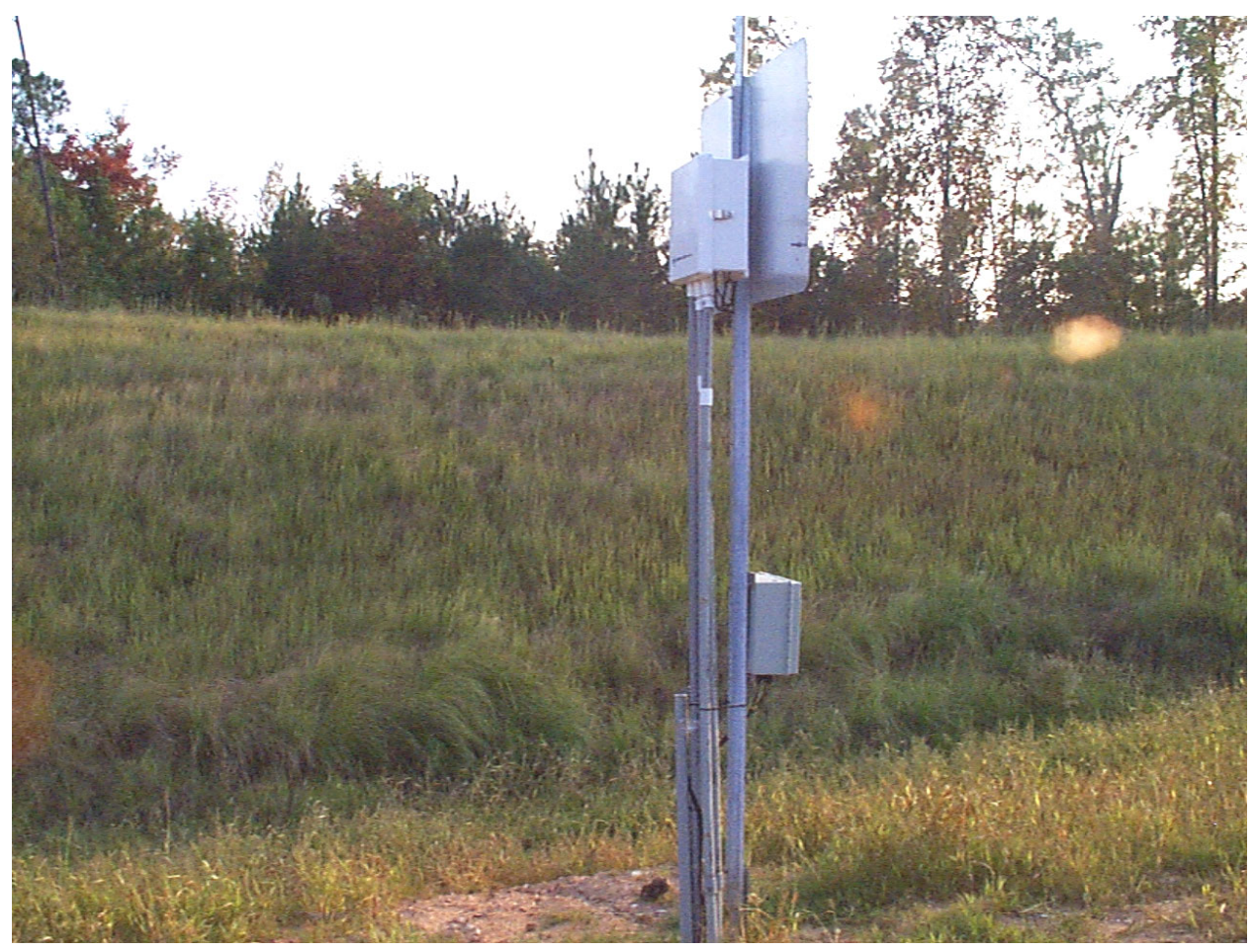

Photo 5. Weather-proof enclosures: Campbell Scientific at top and Troxler at bottom

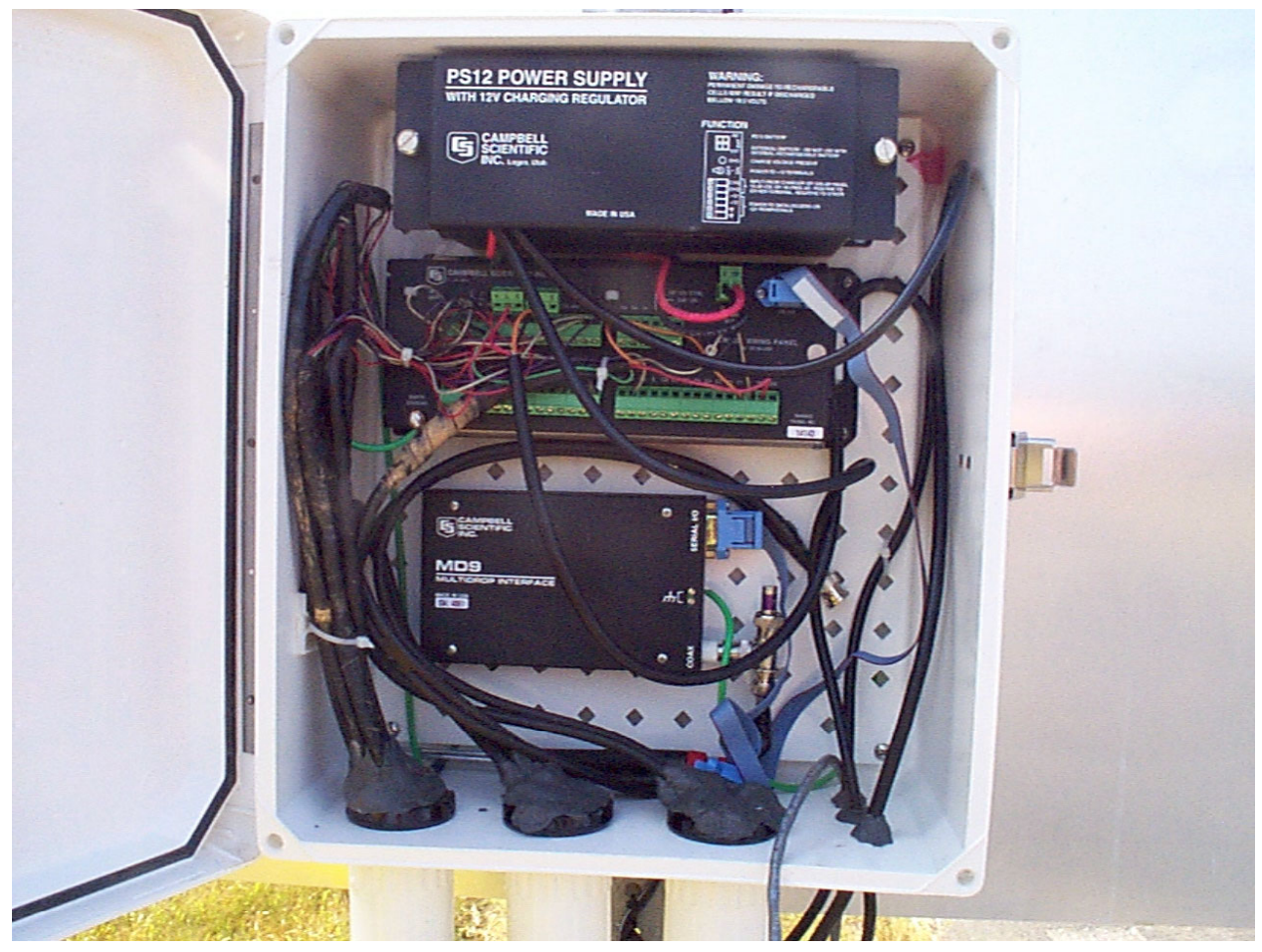

Photo 6. View inside the Campbell Scientific enclosure 


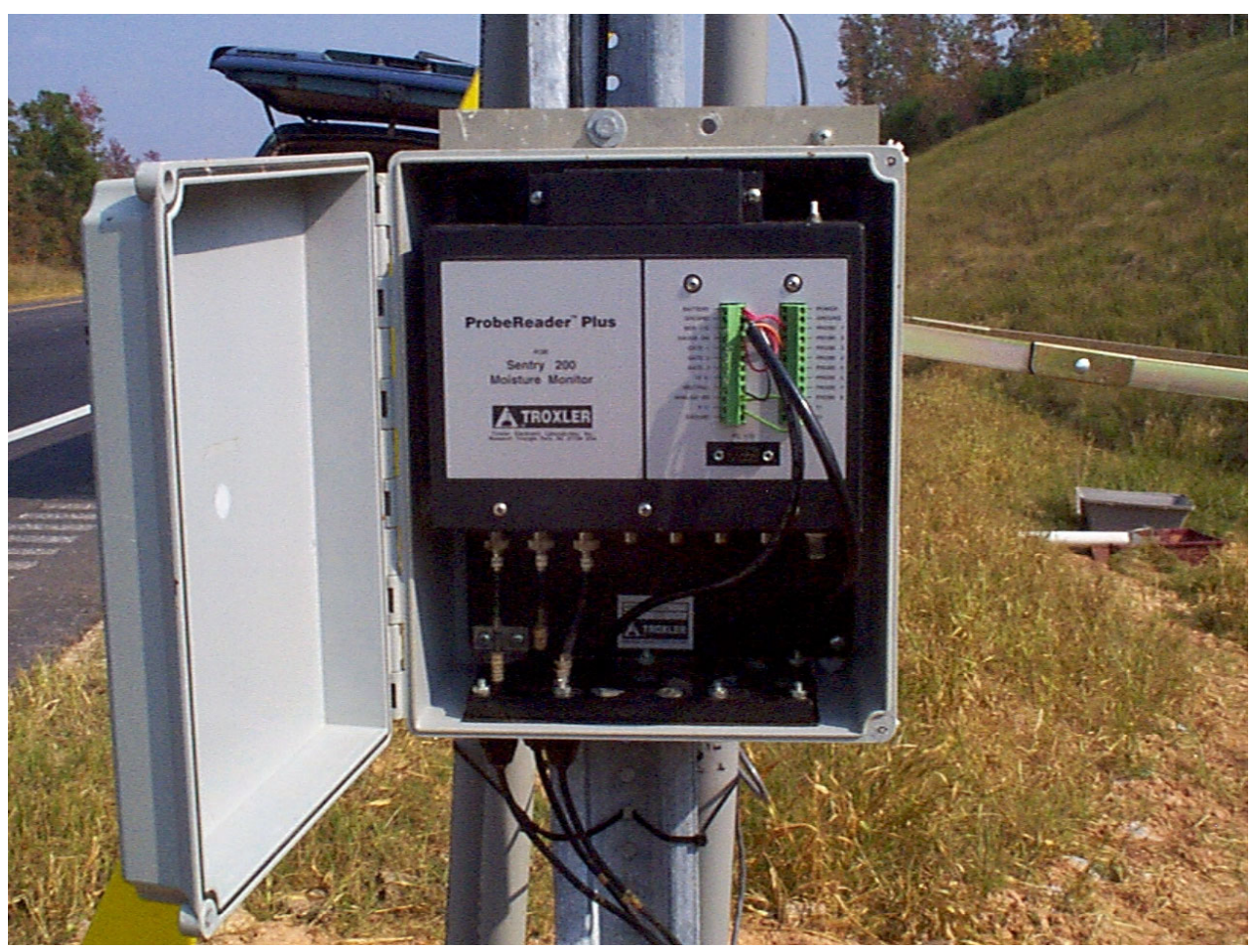

Photo 7. View inside the Troxler enclosure 


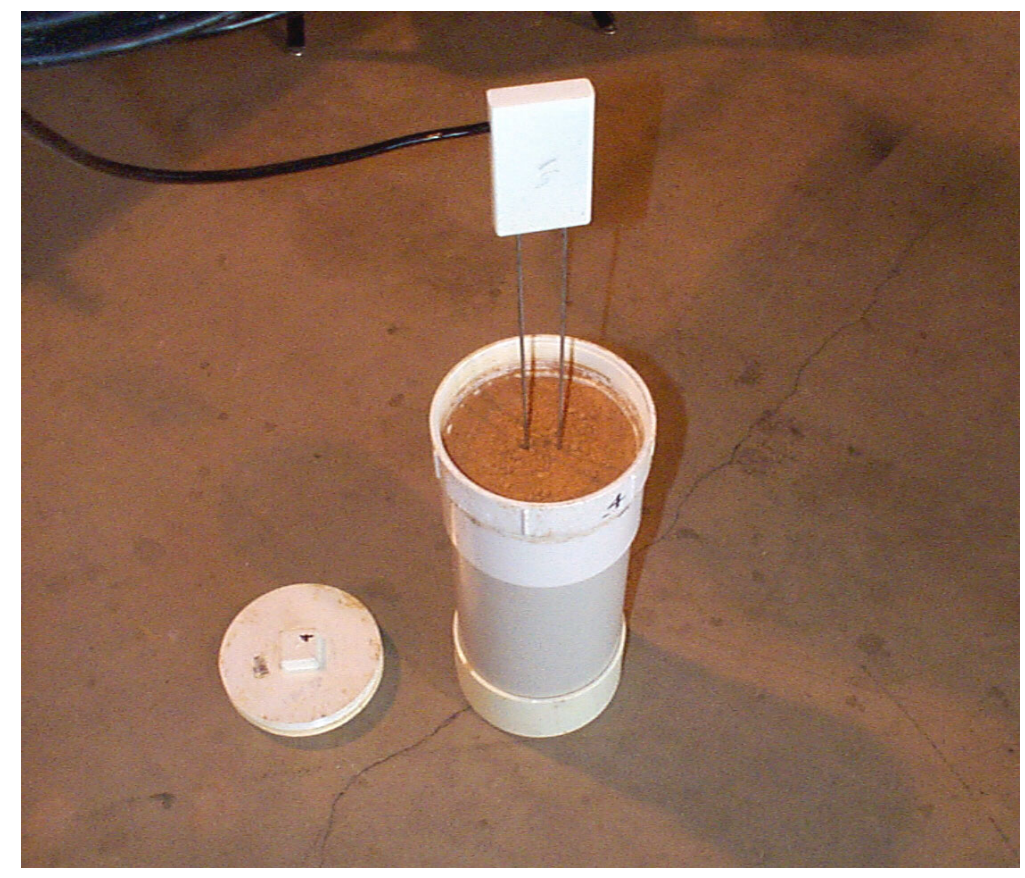

Photo 8. Calibration of the CS615 moisture probes

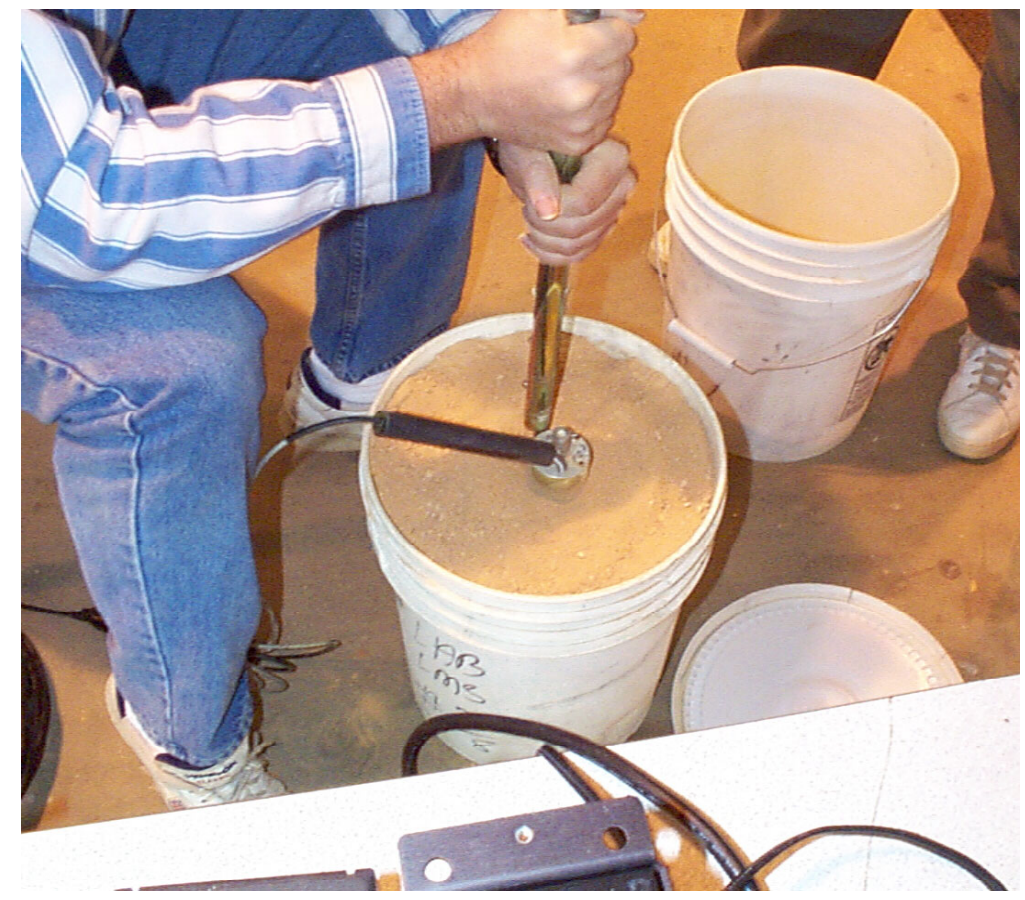

Photo 9. Calibration of the Sentry 200 moisture probes 


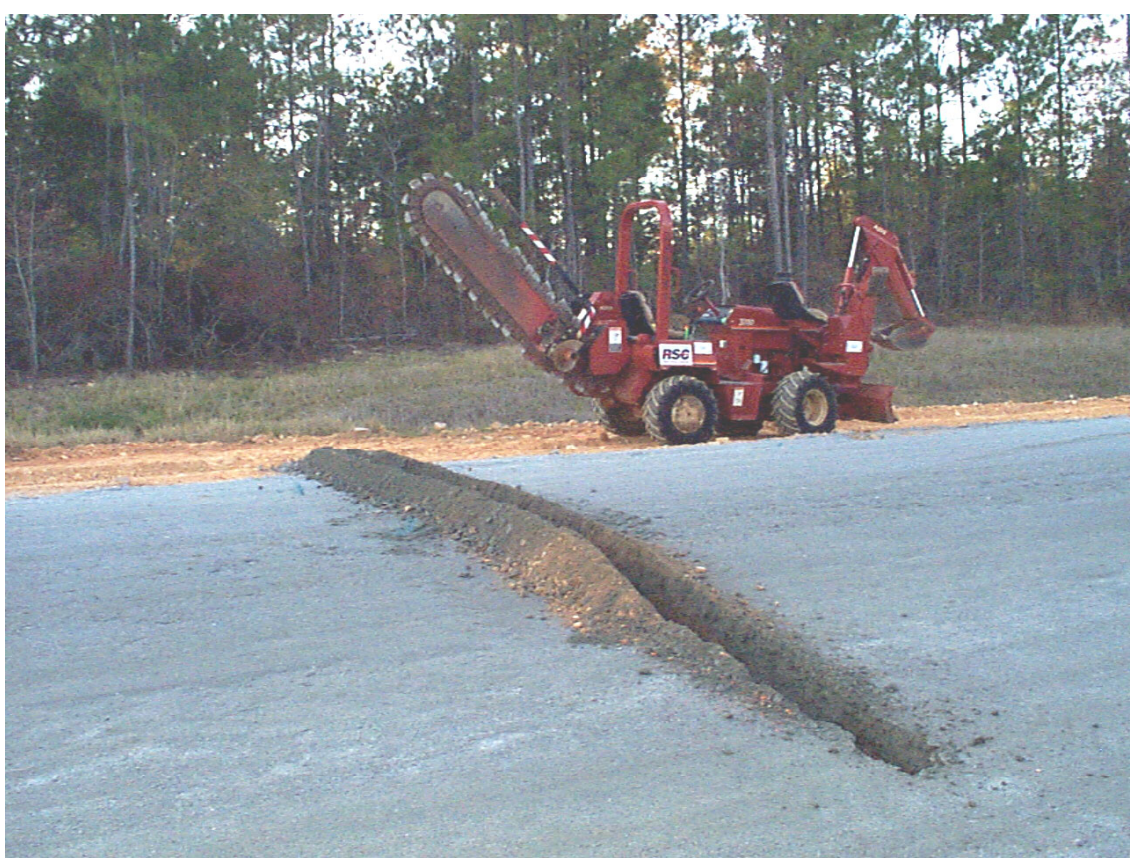

Photo 10. Trench for installing a CS615 moisture probe

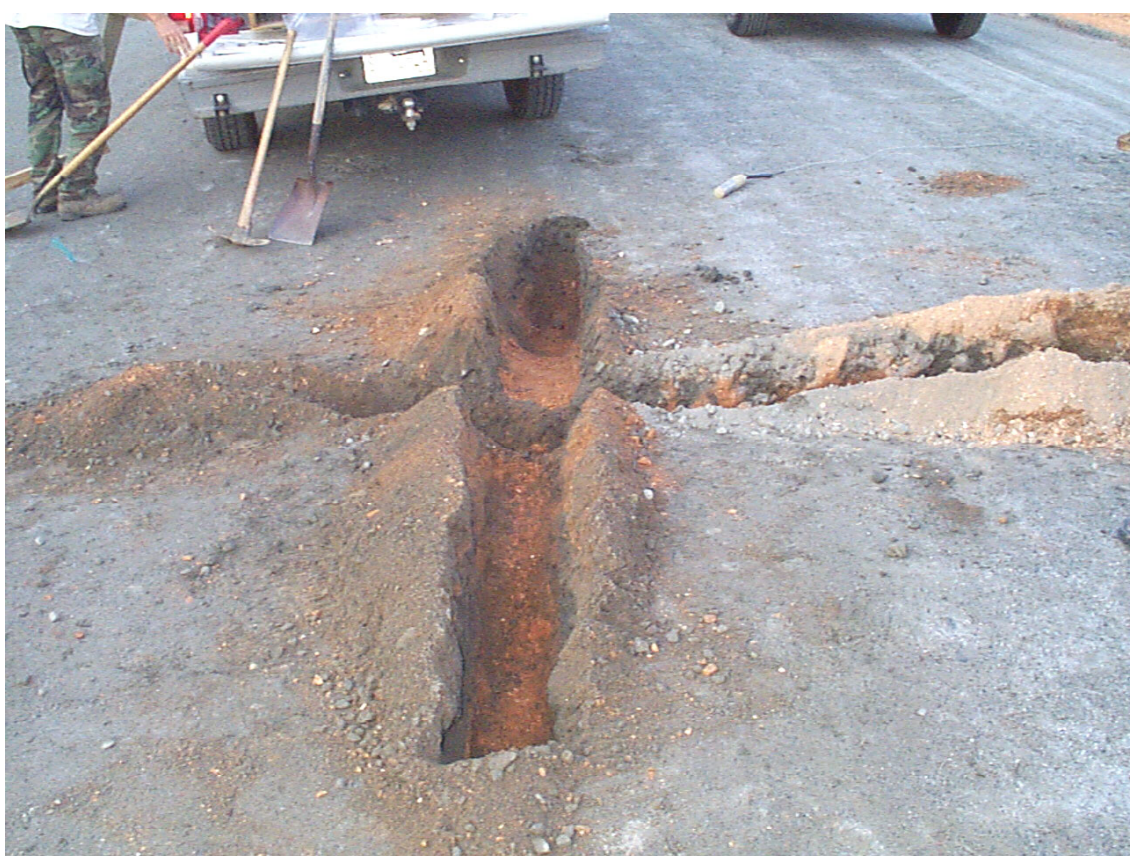

Photo 11. Trench for installing 2 Sentry 200 moisture probes, along with a CS615 moisture probe 


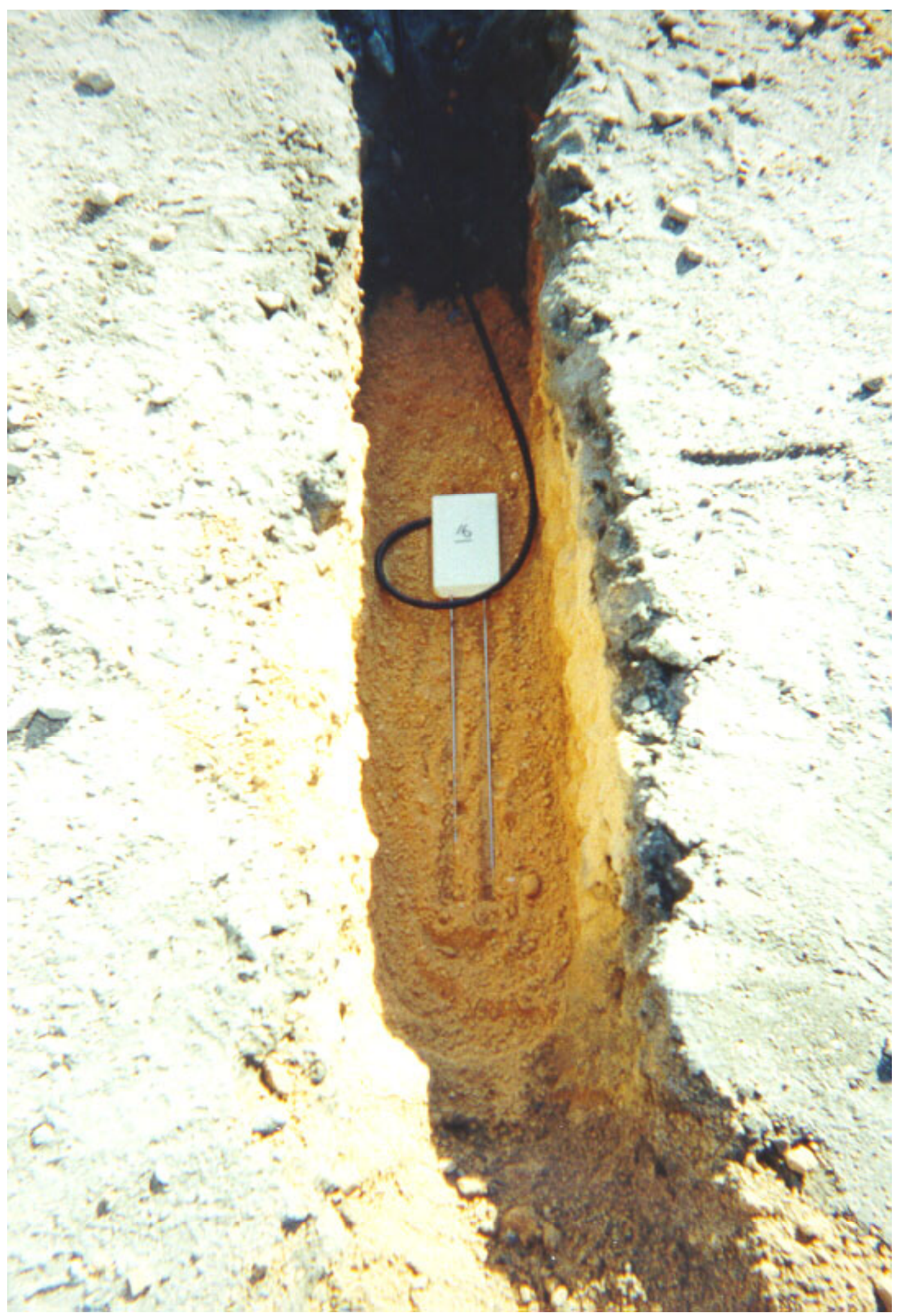

Photo 12. CS615 probe in-place and ready for burial 


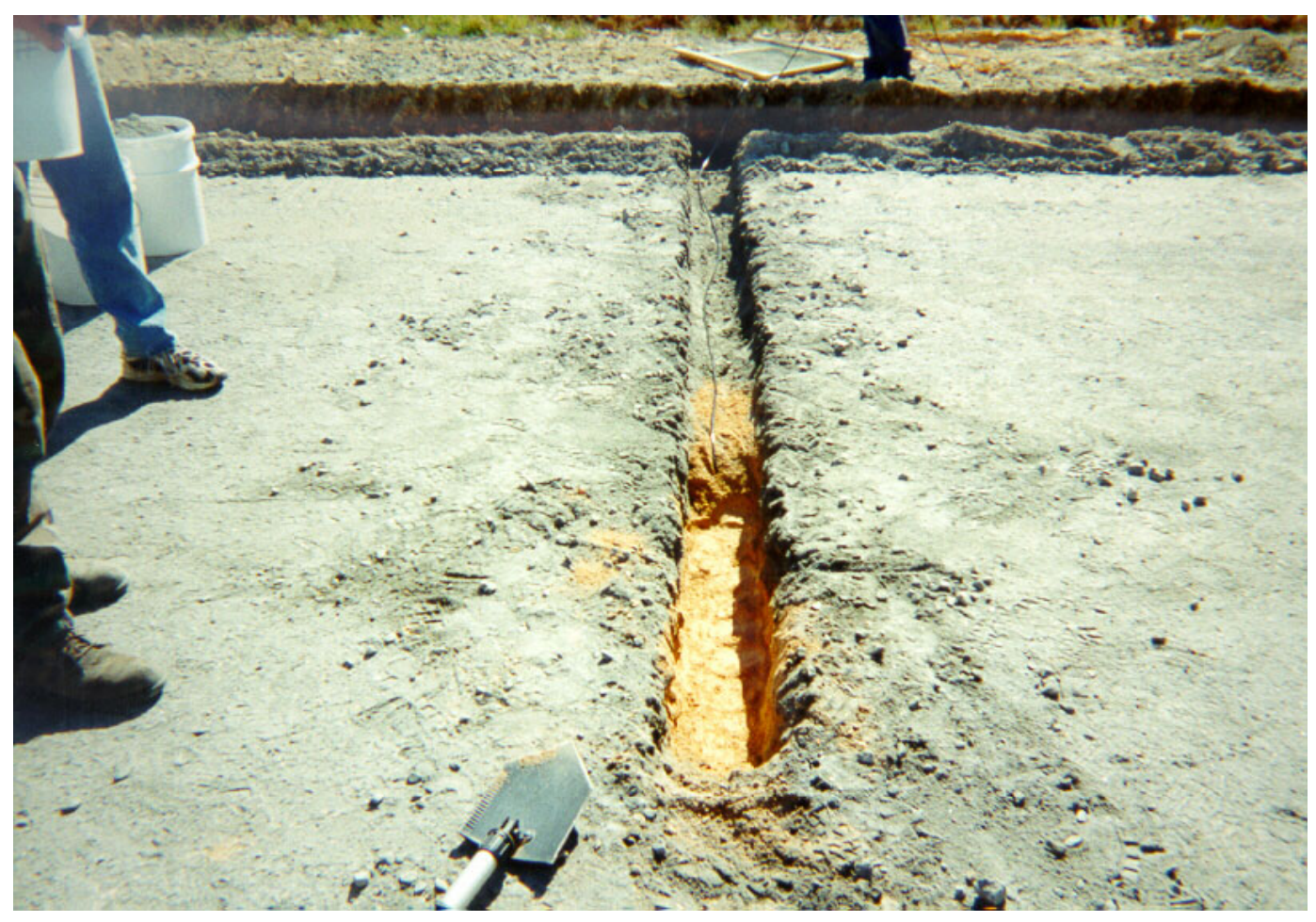

Photo 13. CS615 probe installation after compacting select fill

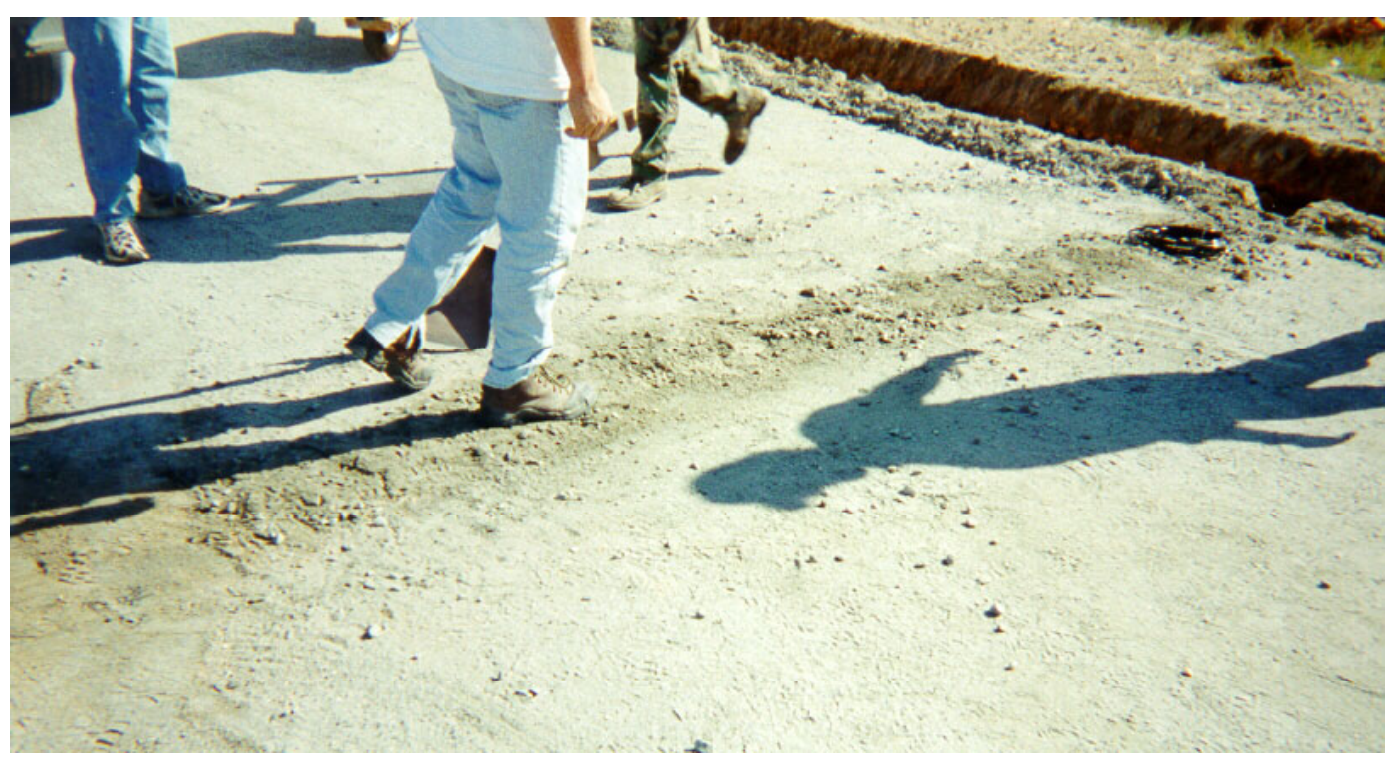

Photo 14. Completed moisture probe installation 


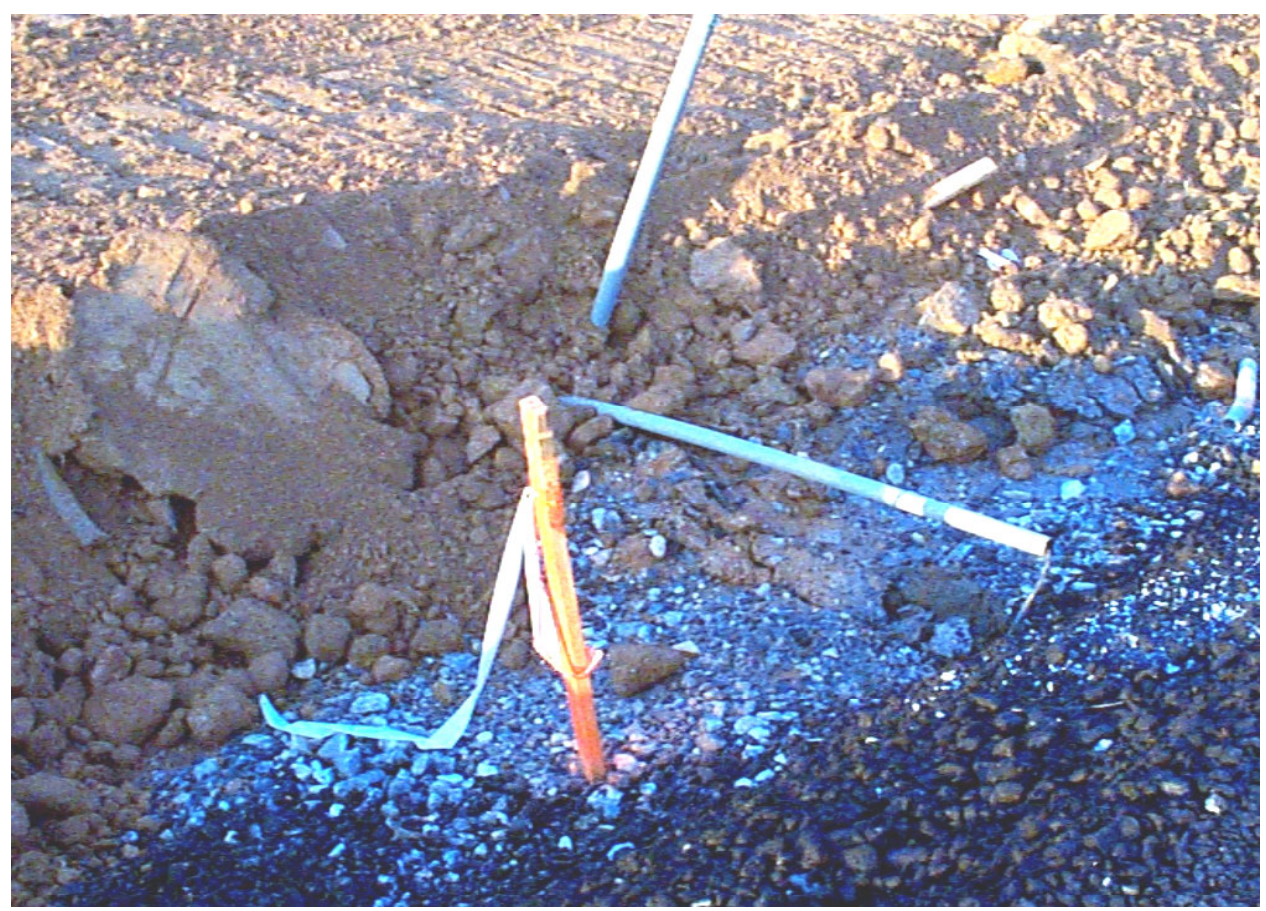

Photo 15. Moisture probe cable threaded through PVC pipe, extending through pavement shoulder

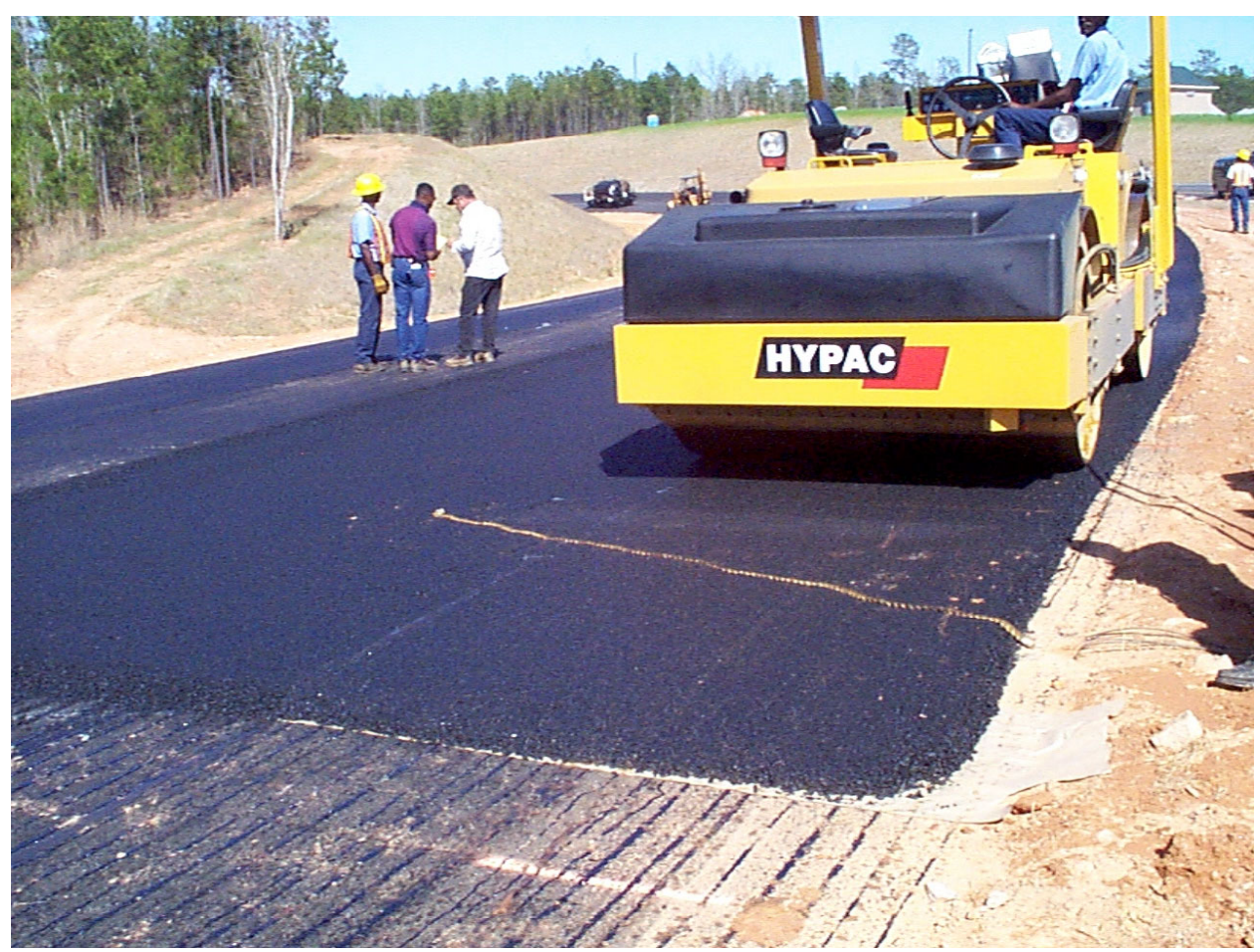

Photo 16. Compacting ropes into asphalt concrete to form temperature probe trenches 


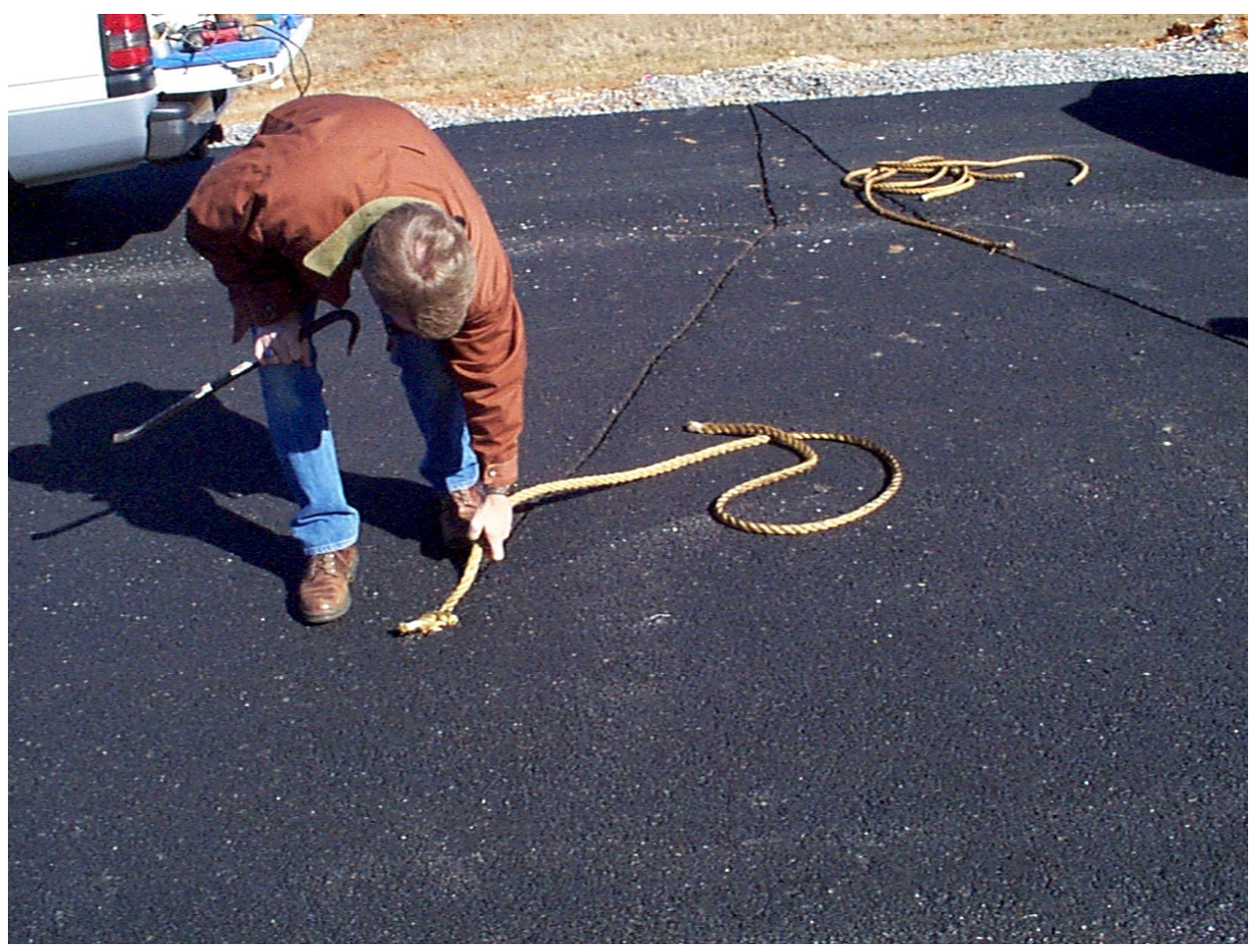

Photo 17. Well-formed trench

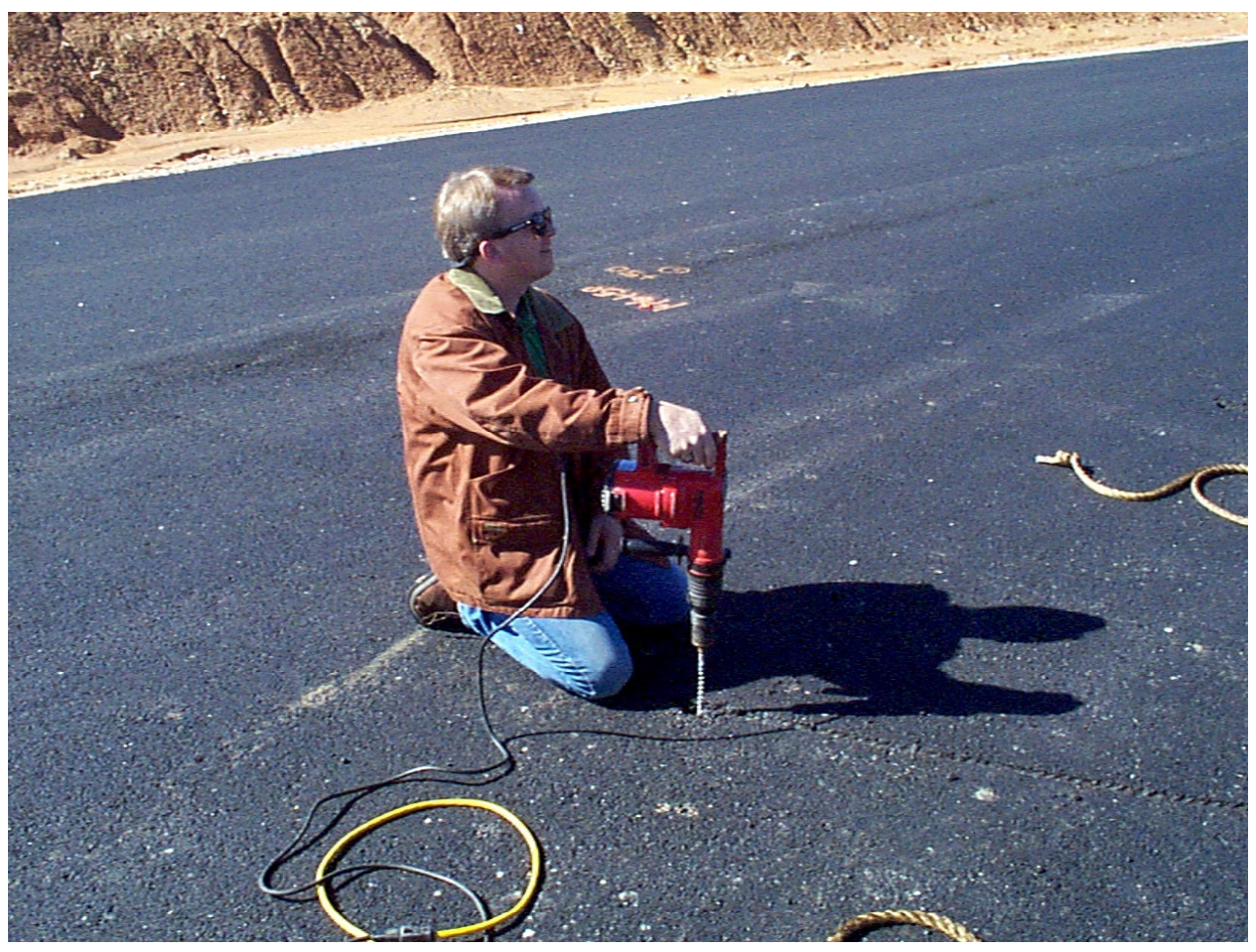

Photo 18. Drilling down to bottom of upper binder course 


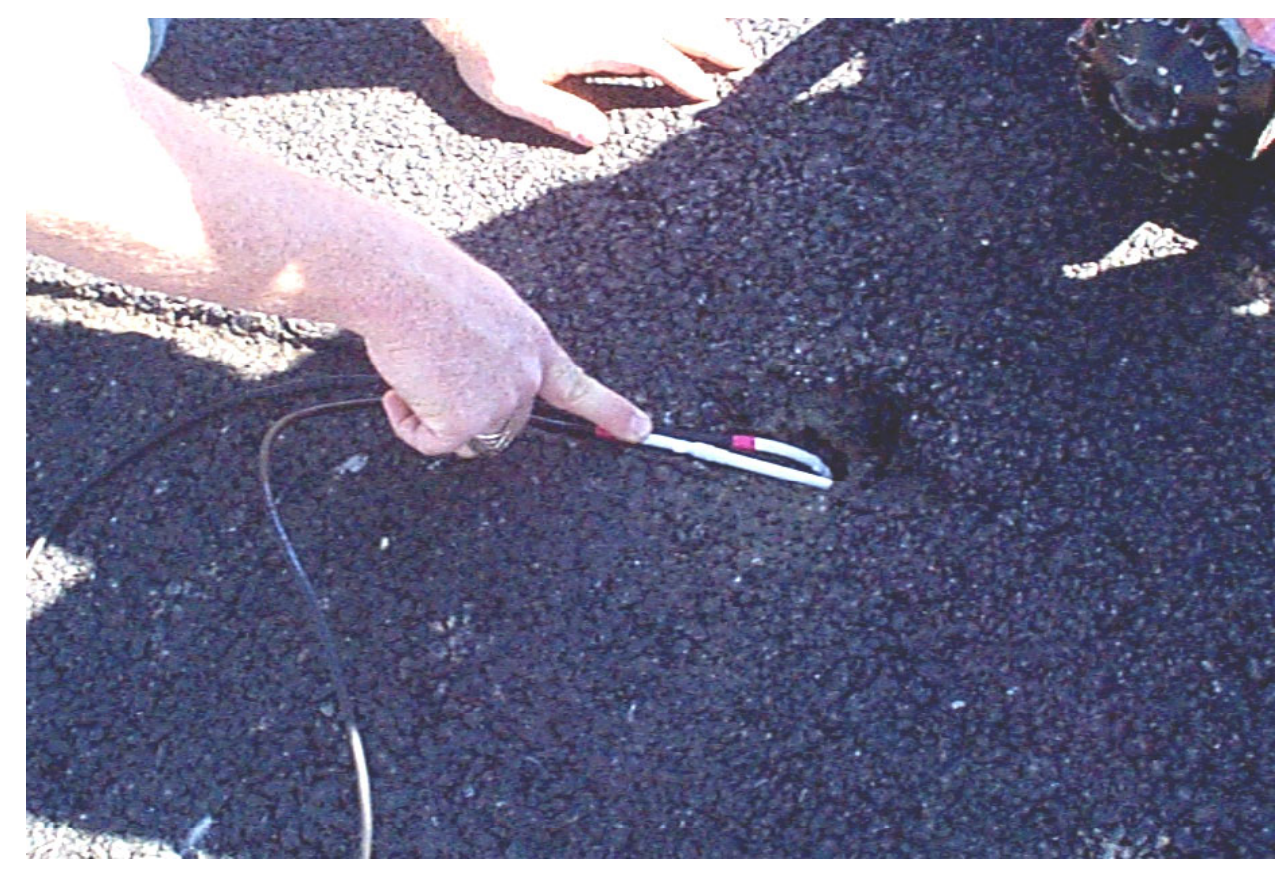

Photo 19. Two thermistors in-position: one vertical in hole and one horizontal

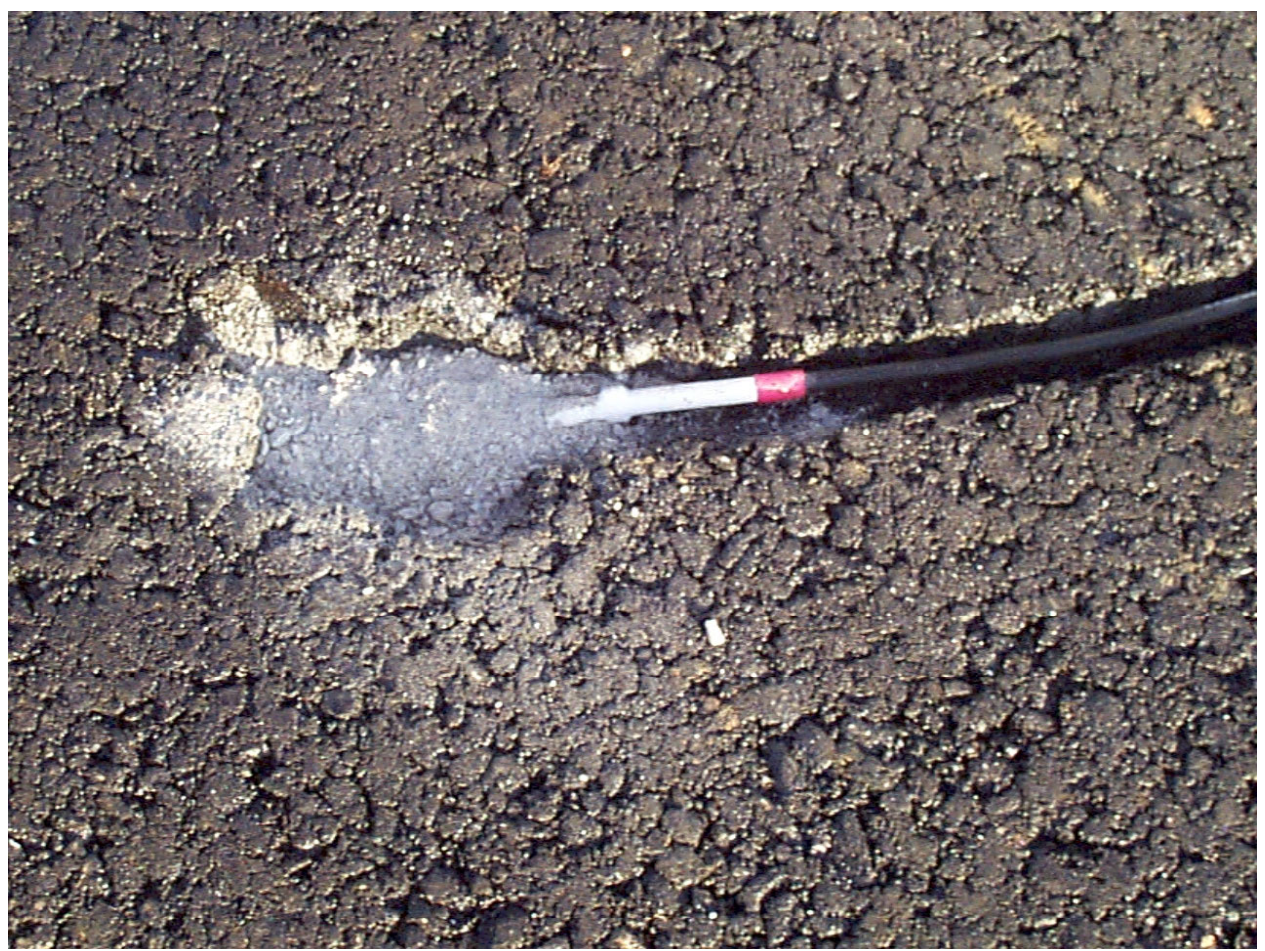

Photo 20. Thermistor protected with fine aggregate 


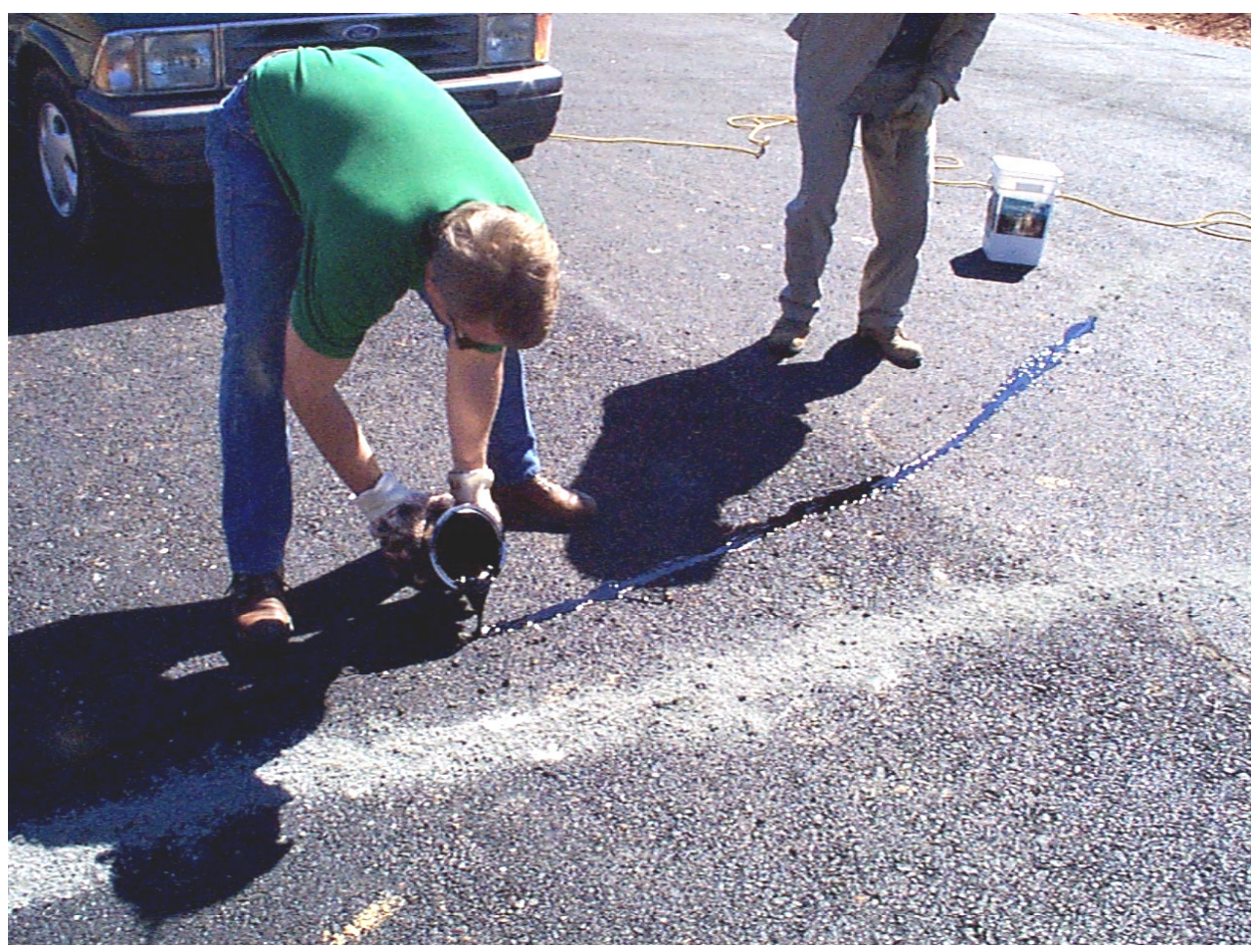

Photo 21. Pouring polymer-modified binder into probe trench

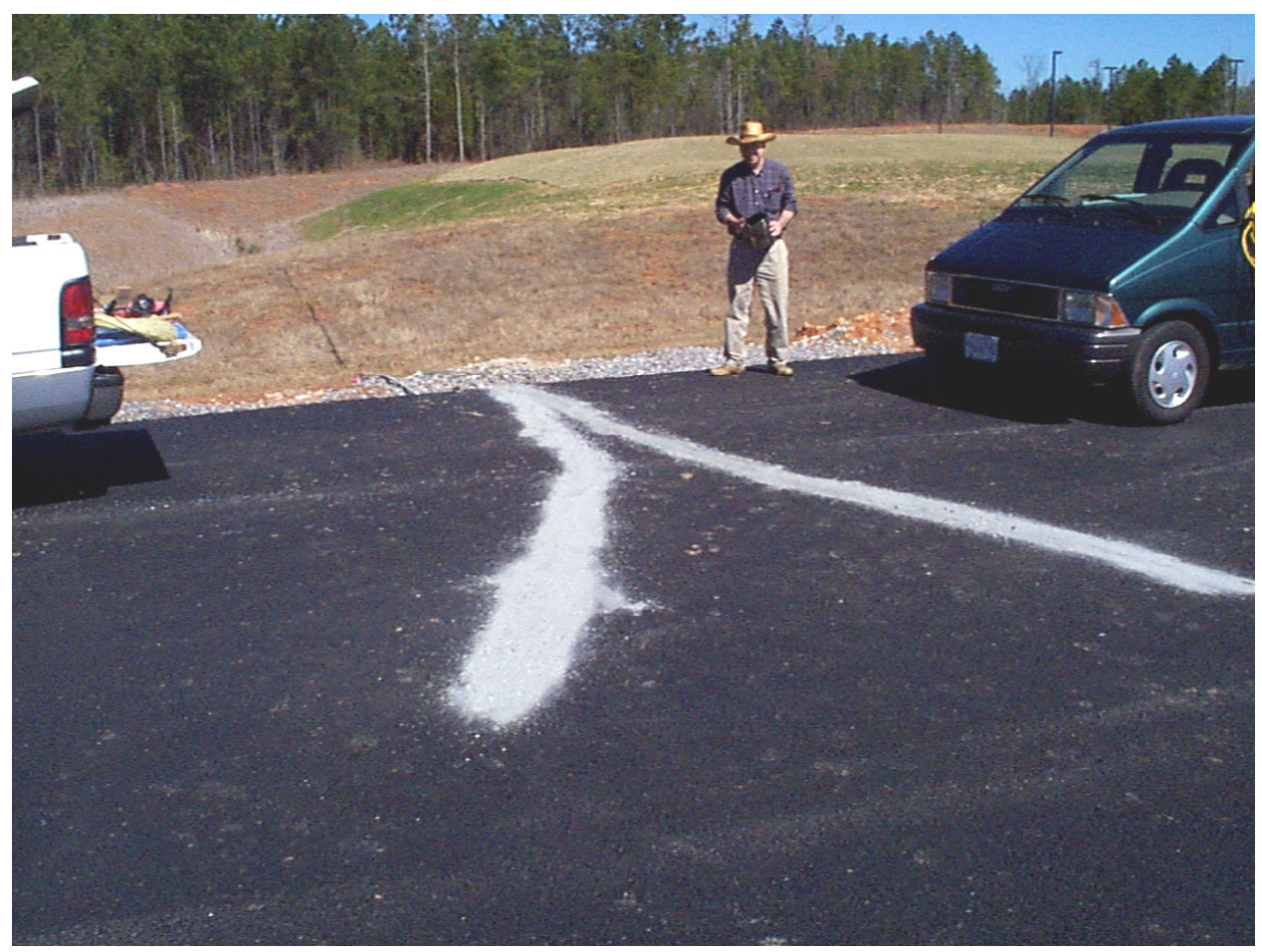

Photo 22. Trench on top of upper binder course, covered with fine aggregate 


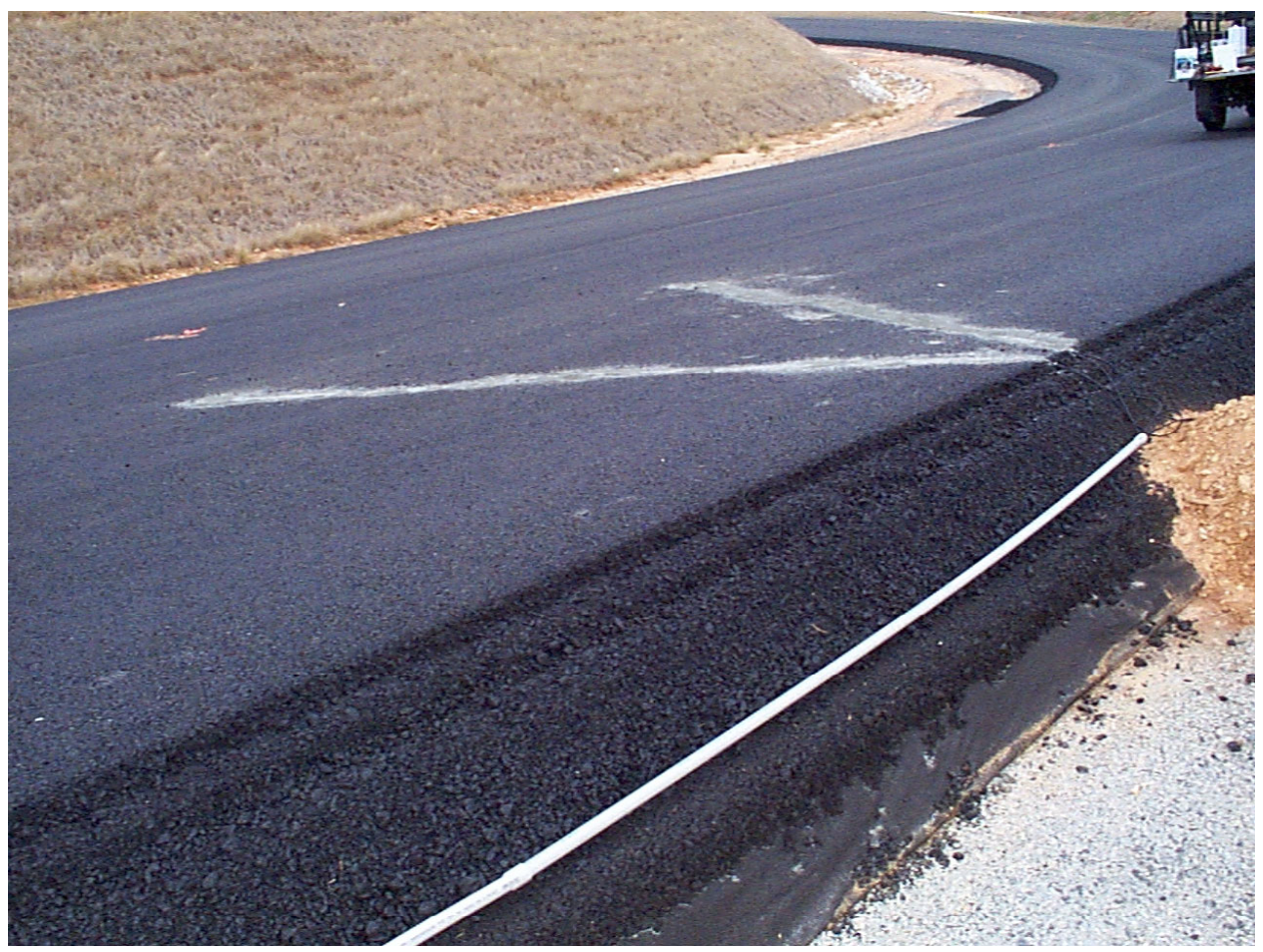

Photo 23. Completed temperature probe installation on top of the upper binder course

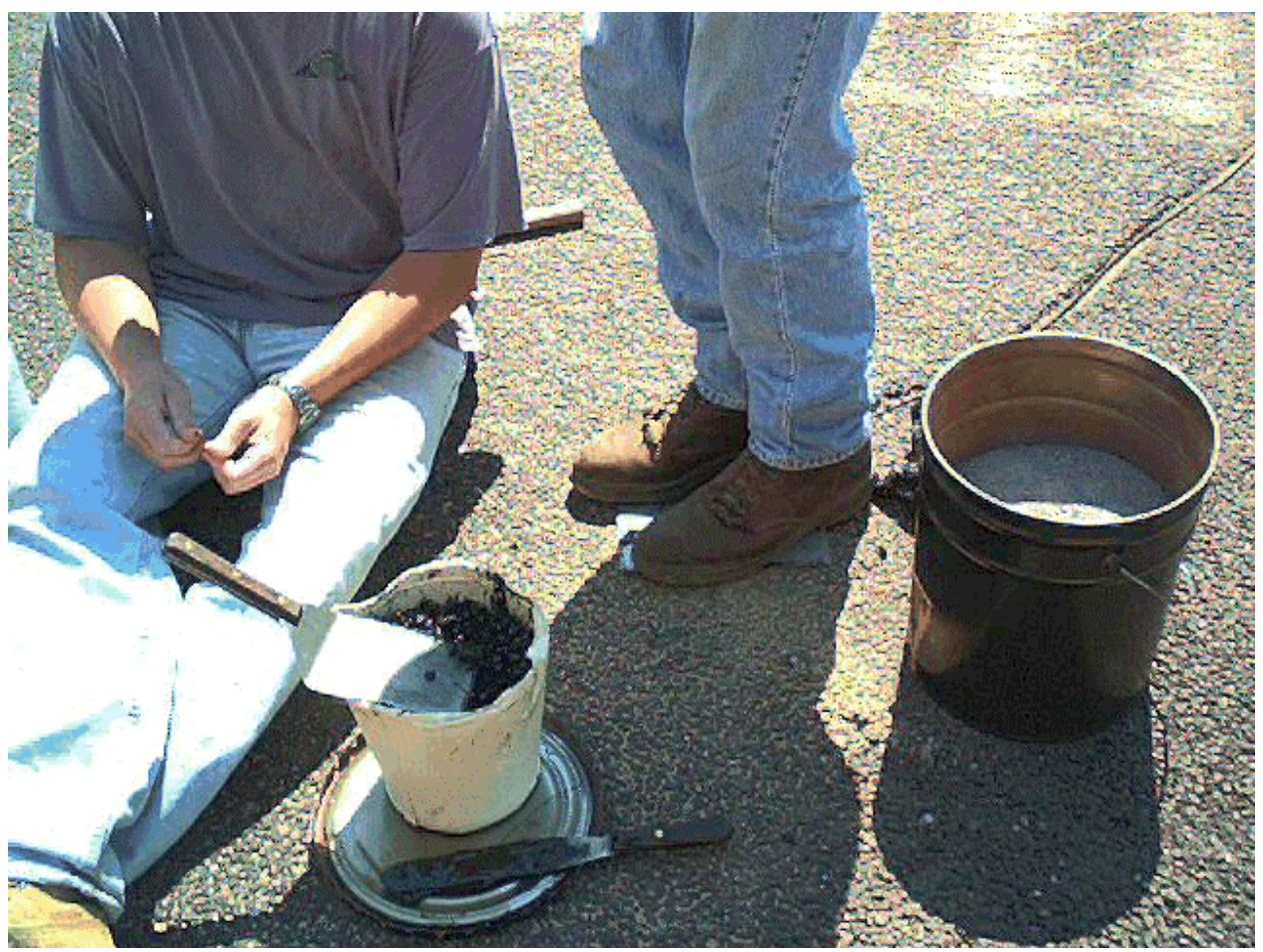

Photo 24. Stepping on a metal plate to compact hot-mix over the probe at the pavement surface 


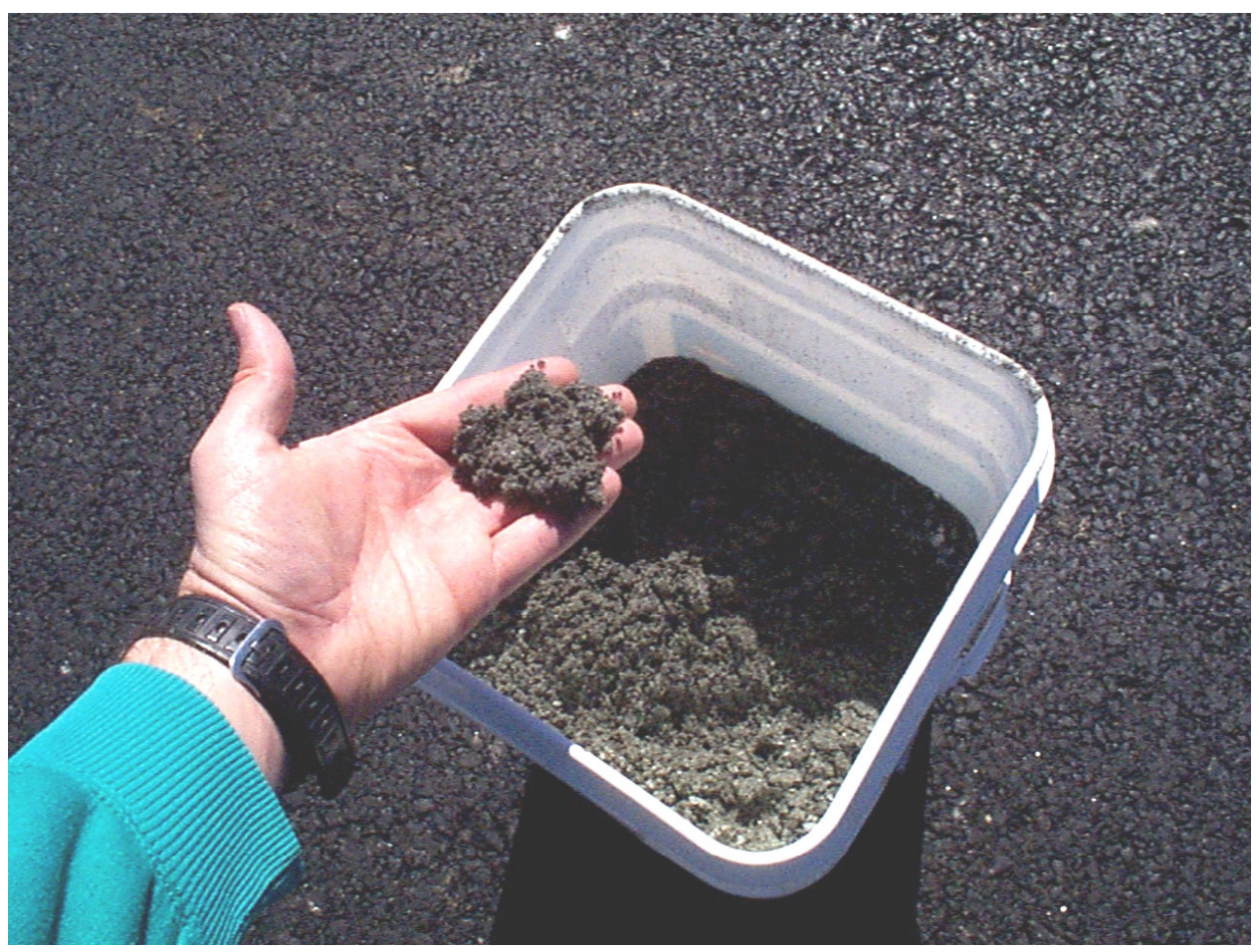

Photo 25. Darker fine aggregate for use at the pavement surface

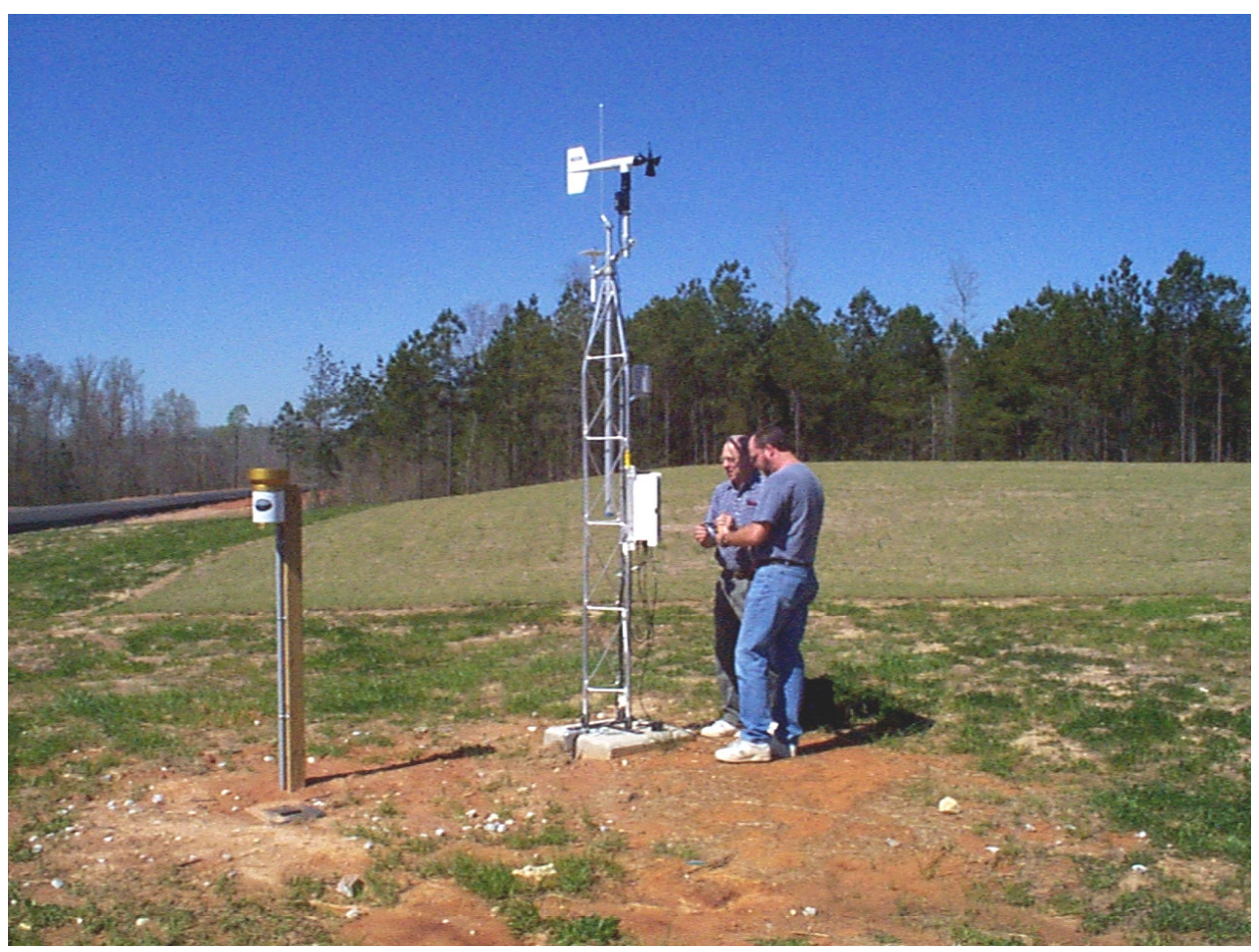

Photo 26. Weather station 


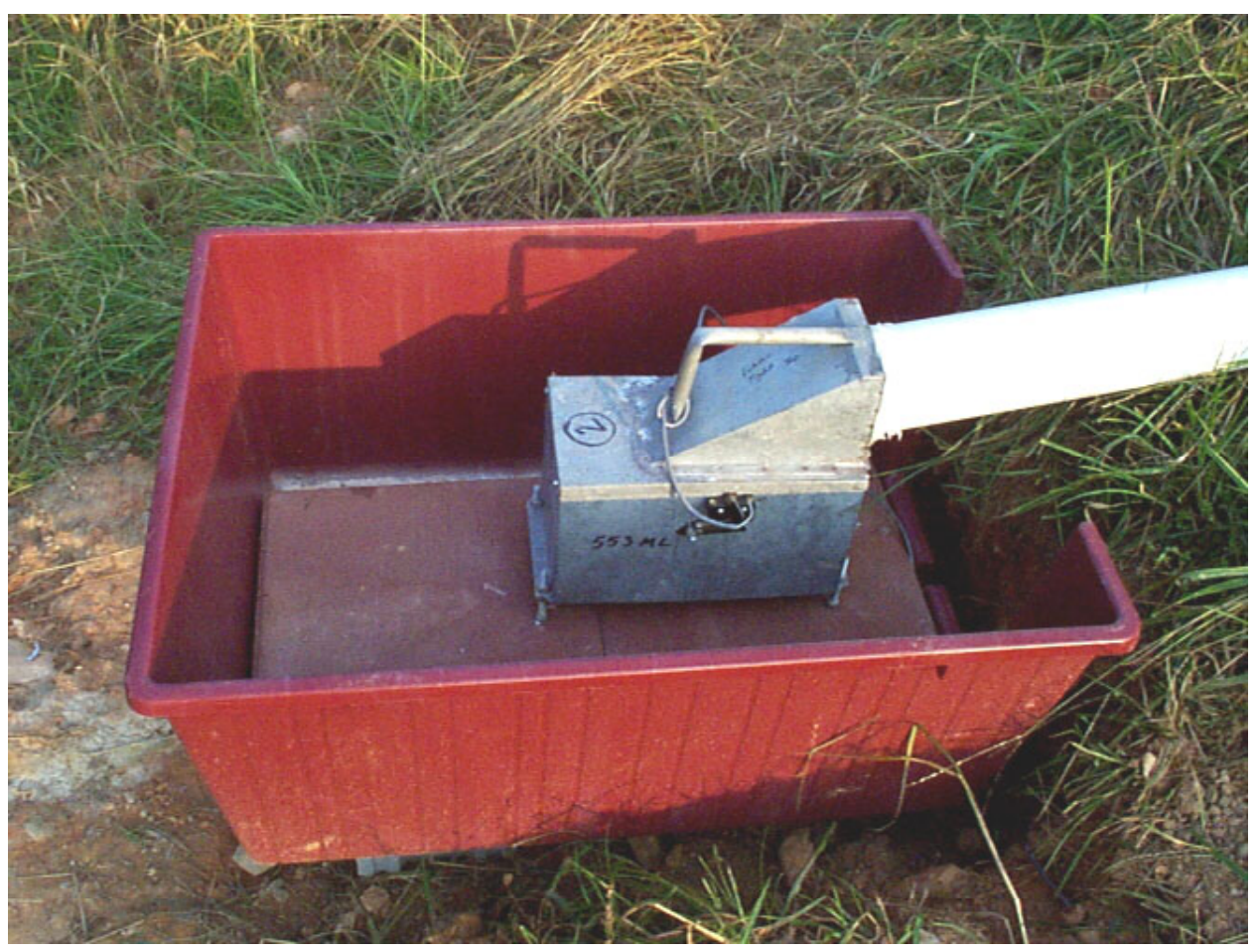

Photo 27. Tipping bucket

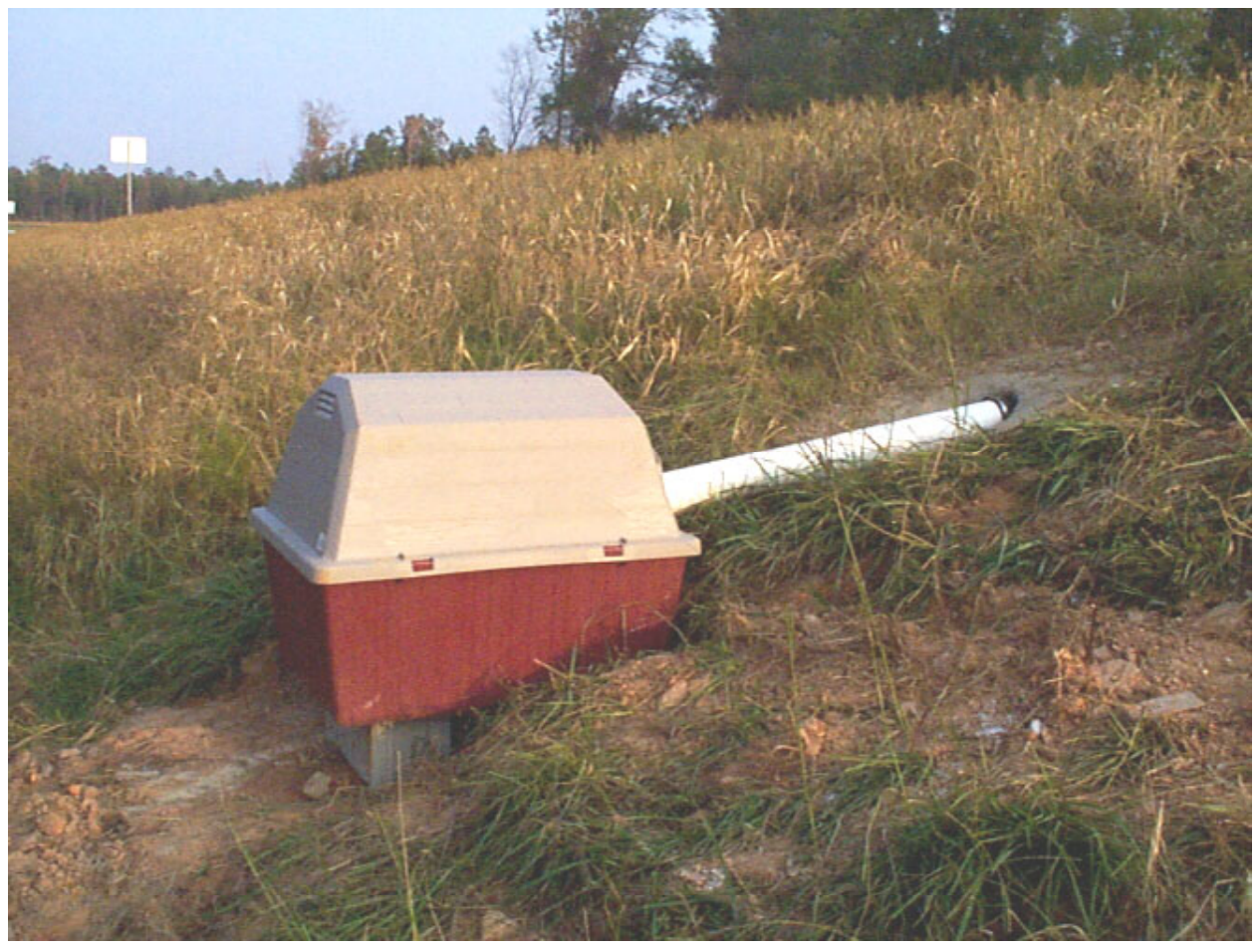

Photo 28. Doghouse enclosure for a tipping bucket 


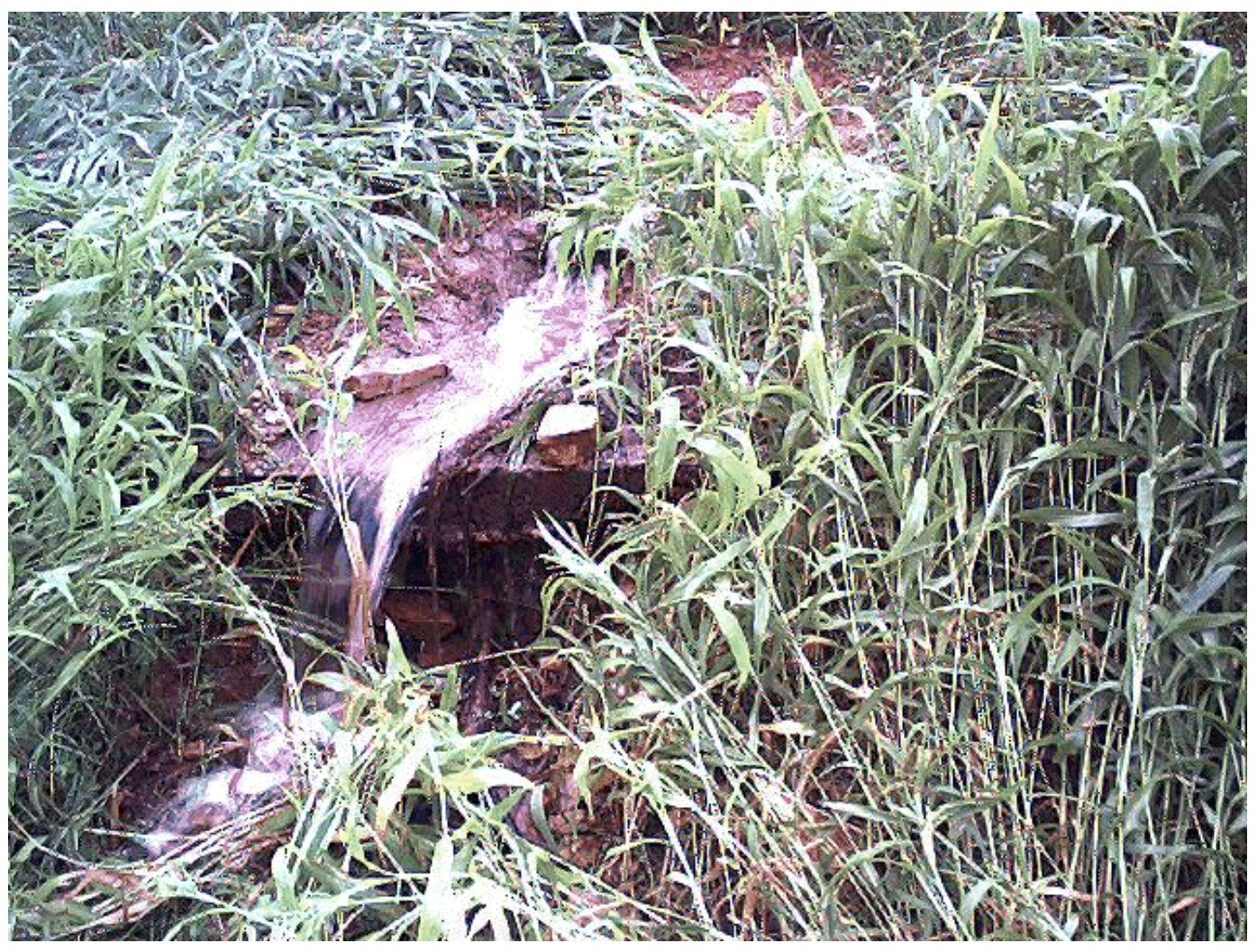

Photo 29. Water flow from drainage system 


\section{Appendix A Statistical Analyses}




\begin{tabular}{|c|c|c|c|c|}
\hline \multicolumn{5}{|c|}{$\begin{array}{l}\text { Table A1 } \\
\text { Analysis of Variance for Campbell Scientific Model } 108 \\
\text { Temperature Probes at Verification Temperature of } 0.44^{\circ} \mathrm{C}\left(32.8^{\circ} \mathrm{F}\right)\end{array}$} \\
\hline Source of Variability & $\begin{array}{l}\text { Degrees of } \\
\text { Freedom }^{1} \\
\end{array}$ & $\begin{array}{l}\text { Sum of } \\
\text { Squares }\end{array}$ & $\begin{array}{l}\text { Mean } \\
\text { Square } \\
\end{array}$ & $\begin{array}{l}\text { Expected Mean } \\
\text { Square }^{2}\end{array}$ \\
\hline Between Probes & $p-1=7$ & 0.01585 & 0.002264 & $\sigma_{\mathrm{w}}^{2}+\mathrm{r}\left({\sigma_{\mathrm{b}}}^{2}\right)$ \\
\hline Between Replicates & $p(r-1)=16$ & 0.07411 & 0.001430 & $\sigma_{w}^{2}$ \\
\hline Total & $\mathrm{pr}-1=23$ & 0.08996 & NA & NA \\
\hline
\end{tabular}

\begin{tabular}{|c|c|c|c|c|}
\hline \multicolumn{5}{|c|}{$\begin{array}{l}\text { Table A2 } \\
\text { Analysis of Variance for Campbell Scientific Model } 108 \\
\text { Temperature Probes at Verification Temperature of } 23.8^{\circ} \mathrm{C}\left(74.9^{\circ} \mathrm{F}\right)\end{array}$} \\
\hline Source of Variability & $\begin{array}{l}\text { Degrees of } \\
\text { Freedom }^{1}\end{array}$ & $\begin{array}{l}\text { Sum of } \\
\text { Squares }\end{array}$ & $\begin{array}{l}\text { Mean } \\
\text { Square }\end{array}$ & $\begin{array}{l}\text { Expected } \\
\text { Mean Square }^{2}\end{array}$ \\
\hline Between Probes & $p-1=7$ & 0.01108 & 0.001583 & $\overline{\sigma_{\mathrm{w}}{ }^{2}+\mathrm{r}\left(\sigma_{\mathrm{b}}{ }^{2}\right)}$ \\
\hline Between Replicates & $p(r-1)=16$ & 0.001549 & 0.00009683 & $\sigma_{w}^{2}$ \\
\hline Total & $p r-1=23$ & 0.01263 & NA & $\mathrm{NA}$ \\
\hline
\end{tabular}

\begin{tabular}{|c|c|c|c|c|}
\hline $\begin{array}{l}\text { Table A3 } \\
\text { Analysis of Vari } \\
\text { Temperature Pr }\end{array}$ & $\begin{array}{l}\text { ce for Car } \\
\text { es at Verif }\end{array}$ & $\begin{array}{l}\text { ell Scie } \\
\text { ion Ter }\end{array}$ & $\begin{array}{l}\text { fic Mode } \\
\text { rature o }\end{array}$ & $\begin{array}{l}08 \\
9.3^{\circ} \mathrm{C}\left(138.8^{\circ}\right.\end{array}$ \\
\hline Source of Variability & $\begin{array}{l}\text { Degrees of } \\
\text { Freedom }^{1} \\
\end{array}$ & $\begin{array}{l}\text { Sum of } \\
\text { Squares }\end{array}$ & $\begin{array}{l}\text { Mean } \\
\text { Square } \\
\end{array}$ & $\begin{array}{l}\text { Expected } \\
\text { Mean Square }^{2}\end{array}$ \\
\hline Between Probes & p-1=7 & 0.06843 & 0.009776 & 拱 ${ }^{2}+\mathrm{r}\left(\sigma_{\mathrm{b}}^{2}\right)$ \\
\hline Between Replicates & $p(r-1)=16$ & 0.008235 & 0.0005147 & $\sigma_{w}{ }^{2}$ \\
\hline Total & $\mathrm{pr}-1=23$ & 0.07667 & NA & NA \\
\hline
\end{tabular}

\begin{tabular}{|c|c|c|c|c|}
\hline \multicolumn{5}{|c|}{$\begin{array}{l}\text { Table A4 } \\
\text { Analysis of Variance for CS615 Calibration Data at Calibration } \\
\text { Moisture Content of } 0.0 \text { percent }\end{array}$} \\
\hline Source of Variability & $\begin{array}{l}\text { Degrees of } \\
\text { Freedom }^{1}\end{array}$ & $\begin{array}{l}\text { Sum of } \\
\text { Squares }\end{array}$ & $\begin{array}{l}\text { Mean } \\
\text { Square } \\
\end{array}$ & $\begin{array}{l}\text { Expected } \\
\text { Mean Square }\end{array}$ \\
\hline Between Probes & p-1 = 25 & (0.01209 & 0.0004836 & 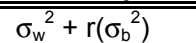 \\
\hline Between Replicates & $p(r-1)=52$ & 0.00741 & 0.0001424 & $\sigma_{\mathrm{w}}{ }^{2}$ \\
\hline Total & $\mathrm{pr}-1=77$ & 0.01950 & NA & NA \\
\hline
\end{tabular}




\begin{tabular}{|c|c|c|c|c|}
\hline \multicolumn{5}{|c|}{$\begin{array}{l}\text { Table A5 } \\
\text { Analysis of Variance for CS615 Calibration Data at Calibration } \\
\text { Moisture Content of } 9.6 \text { percent }\end{array}$} \\
\hline Source of Variability & $\begin{array}{l}\text { Degrees of } \\
\text { Freedom }^{1}\end{array}$ & $\begin{array}{l}\text { Sum of } \\
\text { Squares }\end{array}$ & $\begin{array}{l}\text { Mean } \\
\text { Square }\end{array}$ & $\begin{array}{l}\text { Expected } \\
\text { Mean Square }\end{array}$ \\
\hline Between Probes & p-1 = 25 & (0.01577 & 0.0006310 & " \\
\hline Between Replicates & $p(r-1)=52$ & 0.01392 & 0.0002677 & $\sigma_{\mathrm{w}}{ }^{2}$ \\
\hline Total & $\mathrm{pr}-1=77$ & 0.02969 & NA & NA \\
\hline
\end{tabular}

\begin{tabular}{|c|c|c|c|c|}
\hline \multicolumn{5}{|c|}{$\begin{array}{l}\text { Table A6 } \\
\text { Analysis of Variance for CS615 Calibration Data at Calibration } \\
\text { Moisture Content of } 20.5 \text { percent }\end{array}$} \\
\hline Source of Variability & $\begin{array}{l}\text { Degrees of } \\
\text { Freedom }^{1} \\
\end{array}$ & $\begin{array}{l}\text { Sum of } \\
\text { Squares }\end{array}$ & $\begin{array}{l}\text { Mean } \\
\text { Square } \\
\end{array}$ & $\begin{array}{l}\text { Expected } \\
\text { Mean Square }^{2} \\
\end{array}$ \\
\hline Between Probes & $p-1=25$ & 0.04316 & 0.0017270 & 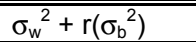 \\
\hline Between Replicates & $p(r-1)=52$ & 0.04942 & 0.0009503 & $\sigma_{w}{ }^{2}$ \\
\hline Total & $\mathrm{pr}-1=77$ & 0.09258 & NA & NA \\
\hline
\end{tabular}

\begin{tabular}{|c|c|c|c|c|}
\hline \multicolumn{5}{|c|}{$\begin{array}{l}\text { Table A7 } \\
\text { Analysis of Variance for Troxler Calibration Data at Calibration } \\
\text { Moisture Content of } 0.0 \text { percent }\end{array}$} \\
\hline Source of Variability & $\begin{array}{l}\text { Degrees of } \\
\text { Freedom }\end{array}$ & $\begin{array}{l}\text { Sum of } \\
\text { Squares }\end{array}$ & $\begin{array}{l}\text { Mean } \\
\text { Square }\end{array}$ & $\begin{array}{l}\text { Expected } \\
\text { Mean Square }\end{array}$ \\
\hline Between Probes & p-1 = 5 & (774221 & 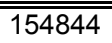 & 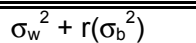 \\
\hline Between Replicates & $p(r-1)=12$ & 4.0 & 0.33 & $\sigma_{w}{ }^{2}$ \\
\hline Total & $\mathrm{pr}-1=17$ & 774225 & $\mathrm{NA}$ & NA \\
\hline
\end{tabular}

\begin{tabular}{|c|c|c|c|c|}
\hline \multicolumn{5}{|c|}{$\begin{array}{l}\text { Table A8 } \\
\text { Analysis of Variance for Troxler Calibration Data at Calibration } \\
\text { Moisture Content of } 7.7 \text { percent }\end{array}$} \\
\hline Source of Variability & $\begin{array}{l}\text { Degrees of } \\
\text { Freedom }^{1}\end{array}$ & $\begin{array}{l}\text { Sum of } \\
\text { Squares }\end{array}$ & $\begin{array}{l}\text { Mean } \\
\text { Square }\end{array}$ & $\begin{array}{l}\text { Expected } \\
\text { Mean Square }\end{array}$ \\
\hline Between Probes & p-1 =5 & (940072 & 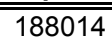 & " \\
\hline Between Replicates & $p(r-1)=12$ & 48 & 4.0 & $\sigma_{\mathrm{w}}{ }^{2}$ \\
\hline Total & $\mathrm{pr}-1=17$ & 940120 & $\mathrm{NA}$ & NA \\
\hline
\end{tabular}




\begin{tabular}{|c|c|c|c|c|}
\hline $\begin{array}{l}\text { Table A9 } \\
\text { Analysis of Vari } \\
\text { Moisture Conte }\end{array}$ & $\begin{array}{l}\text { e for Tr } \\
\text { f } 14.0 \text { p }\end{array}$ & $\begin{array}{l}\text { Calibı } \\
\text { t }\end{array}$ & n Dat & alibration \\
\hline Source of Variability & $\begin{array}{l}\text { Degrees of } \\
\text { Freedom }^{1} \\
\end{array}$ & $\begin{array}{l}\text { Sum of } \\
\text { Squares }\end{array}$ & $\begin{array}{l}\text { Mean } \\
\text { Square }\end{array}$ & $\begin{array}{l}\text { Expected } \\
\text { Mean Square } \\
\end{array}$ \\
\hline Between Probes & p-1=5 & 1860944 & 372189 & $\sigma_{w}{ }^{2}+r\left(\sigma_{b}{ }^{2}\right)$ \\
\hline Between Replicates & $p(r-1)=12$ & 11 & 0.89 & $\sigma_{\mathrm{w}}{ }^{2}$ \\
\hline Total & $\mathrm{pr}-1=17$ & 1860955 & NA & NA \\
\hline
\end{tabular}

\section{Table A10}

Analysis of Variance for Troxler Calibration Data at Calibration Moisture Content of 19.9 percent

\begin{tabular}{|c|c|c|c|c|}
\hline Source of Variability & $\begin{array}{l}\text { Degrees of } \\
\text { Freedom }^{1}\end{array}$ & $\begin{array}{l}\text { Sum of } \\
\text { Squares }\end{array}$ & $\begin{array}{l}\text { Mean } \\
\text { Square }\end{array}$ & $\begin{array}{l}\text { Expected } \\
\text { Mean Square }^{2}\end{array}$ \\
\hline Between Probes & p-1=5 & 2475382 & 40495076 & $\sigma_{\mathrm{w}}{ }^{2}+\mathrm{r}\left(\sigma_{\mathrm{b}}{ }^{2}\right)$ \\
\hline Between Replicates & $p(r-1)=12$ & 16 & 1.3 & $\sigma_{\mathrm{w}}{ }^{2}$ \\
\hline Total & $\mathrm{pr}-1=17$ & 2475398 & NA & NA \\
\hline
\end{tabular}




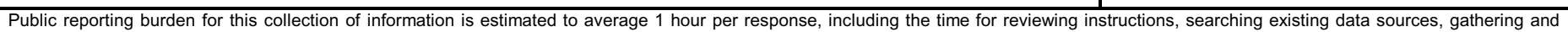

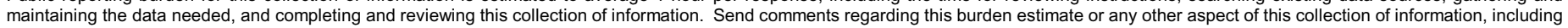

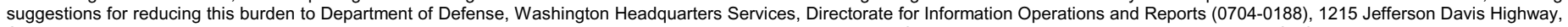

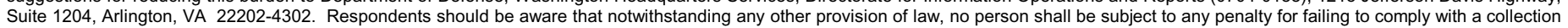
of information if it does not display a currently valid OMB control number. PLEASE DO NOT RETURN YOUR FORM TO THE ABOVE ADDRESS.

\begin{tabular}{|l|l|l}
\hline $\begin{array}{l}\text { 1. REPORT DATE (DD-MM-YYYY) } \\
\text { August } 2001\end{array}$ & $\begin{array}{l}\text { 2. REPORT TYPE } \\
\text { Final report }\end{array}$ & \\
\hline 4. TITLE AND SUBTITLE &
\end{tabular}

4. TITLE AND SUBTITLE

3. DATES COVERED (From - To)

Instrumentation at the National Center for Asphalt Technology Test Track

5a. CONTRACT NUMBER

5b. GRANT NUMBER

5c. PROGRAM ELEMENT NUMBER

6. AUTHOR(S)

Reed B. Freeman, H. Tommy Carr, Tom McEwen, R. Buzz Powell

\section{5d. PROJECT NUMBER}

5e. TASK NUMBER

5f. WORK UNIT NUMBER

AT40-AP-005

7. PERFORMING ORGANIZATION NAME(S) AND ADDRESS(ES)

U.S. Army Engineer Research and Development Center

Geotechnical and Structures Laboratory and Information Technology Laboratory

8. PERFORMING ORGANIZATION

REPORT NUMBER

3909 Halls Ferry Road

Vicksburg, MS 39180-6199

9. SPONSORING/MONITORING AGENCY NAME(S) AND ADDRESS(ES)

U.S. Army Corps of Engineers

Washington, DC 20314-1000

ERDC TR-01-9

\section{DISTRIBUTION/AVAILABILITY STATEMENT}

Approved for public release; distribution is unlimited.

\section{SUPPLEMENTARY NOTES}

\section{ABSTRACT}

The National Center for Asphalt Technology (NCAT) completed construction of a 2.7-km oval test track during the year 2000. The Geotechnical and Structures Laboratory (GSL) of the U.S. Army Engineer Research and Development Center (ERDC) assisted with the installation of instrumentation for environmental monitoring. This report documents the calibration and installation of moisture probes, temperature probes, and tipping buckets. The moisture probes were placed beneath the pavement structure, near the top of select fill material. The temperature probes were placed at various depths in the asphalt concrete. The tipping buckets were positioned at subsurface drainage outlets. The collaboration between GSL, NCAT, and a private consultant resulted in the successful installation of 23 dataloggers, 184 temperature probes, 29 moisture probes, and 3 tipping buckets.

\section{SUBJECT TERMS}

Accelerated pavement testing

Environmental monitoring

Moisture probes

16. SECURITY CLASSIFICATION OF:

a. REPORT

UNCLASSIFIED b. ABSTRACT

UNCLASSIFIED
Pavement instrumentation

Temperature probes

Tipping buckets

\begin{tabular}{|c|c|c|c|}
\hline & $\begin{array}{l}\text { 17. LIMITATION } \\
\text { OF ABSTRACT }\end{array}$ & $\begin{array}{l}\text { 18. NUMBER } \\
\text { OF PAGES }\end{array}$ & 19a. NAME OF RESPONSIBLE PERSON \\
\hline $\begin{array}{l}\text { c. THIS PAGE } \\
\text { UNCLASSIFIED }\end{array}$ & & 66 & $\begin{array}{l}\text { 19b. TELEPHONE NUMBER (include area } \\
\text { code) }\end{array}$ \\
\hline
\end{tabular}

Standard Form 298 (Rev. 8/98)

Prescribed by ANSI Std. 239-18 

Destroy this report when no longer needed. Do not return it to the originator. 